\title{
Baseline Risk Assessment for the Quarry Residuals Operable Unit of the Weldon Spring Site, Weldon Spring, Missouri
}

February 1998

prepared by

Environmental Assessment Division, Argonne National Laboratory

prepared for

U.S. Department of Energy, Weldon Spring Site Remedial Action Project, Weldon Spring, Missouri, under Contract W-31-109-Eng-38

DISTRIBUTION OF THS DOCUNENT IS UNLITEO 


\section{DISCLAMER}

This report was prepared as an account of work sponsored by an agency of the United States Government. Neither the United States Government nor any agency thereof, nor any of their employees, makes any wartanty, express or implied, or assumes any legal liability or responsibility for the accuracy, completeness, or usefulness of any information, apparatus, product, or process disclosed, or represents that its use would not infringe privately owned rights. Reference herein to any specific commercial product, process, or service by trade name, trademark, manufacturer, or otherwise does not necessarily constitute or imply its endorsement, recommendation, or favoring by the United States Government or any agency thereof. The views and opinions of authors expressed herein do not necessarily state or reflect those of the United States Government or any agency thereof. 


\section{DISCLAIMER}

Portions of this document may be illegible electronic image products. Images are produced from the best available original document. 


\section{CONTENTS}

NOTATION $\ldots \ldots \ldots \ldots \ldots \ldots \ldots \ldots \ldots \ldots \ldots \ldots \ldots \ldots \ldots \ldots \ldots \ldots \ldots \ldots$

ENGLISH/METRIC AND METRIC/ENGLISH EQUIVALENTS $\ldots \ldots \ldots \ldots \ldots \ldots \ldots$

$1 \quad$ INTRODUCTION $\ldots \ldots \ldots \ldots \ldots \ldots \ldots \ldots \ldots \ldots \ldots \ldots \ldots \ldots \ldots \ldots$

1.1 Scope of the Baseline Risk Assessment $\ldots \ldots \ldots \ldots \ldots \ldots \ldots \ldots \ldots$

1.2 Objectives of the Baseline Risk Assessment $\ldots \ldots \ldots \ldots \ldots \ldots \ldots \ldots \ldots \ldots$

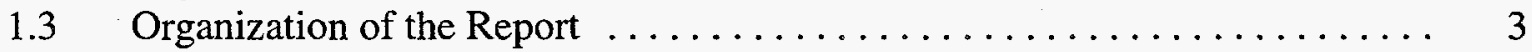

2 IDENTIFICATION OF CONTAMINANTS OF CONCERN $\ldots \ldots \ldots \ldots \ldots$

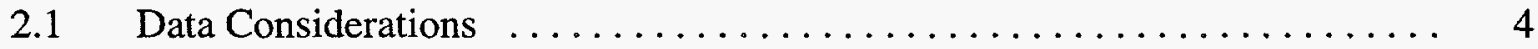

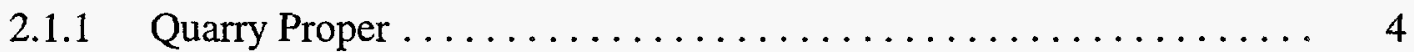

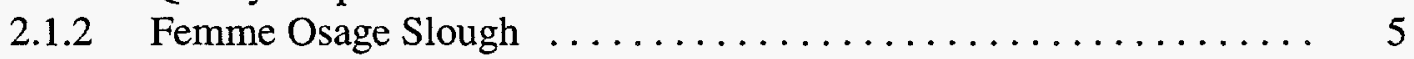

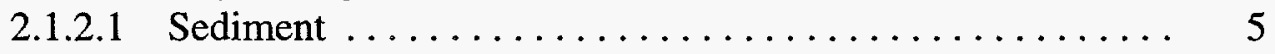

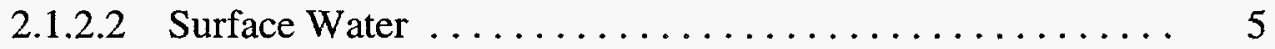

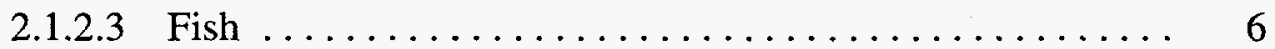

2.1.3 Femme Osage Creek and Little Femme Osage Creek .......... 6

2.1.3.1 Sediment ......................... 6

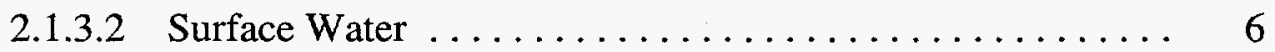

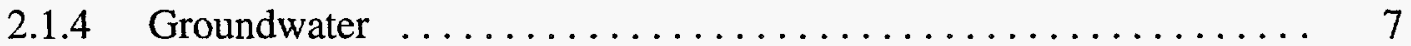

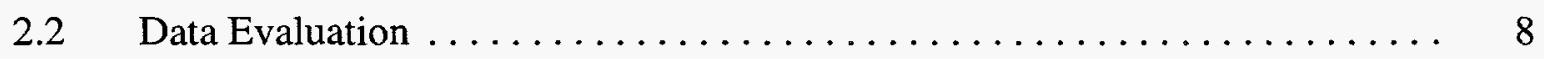

2.2.1 Human Health Contaminants of Potential Concern ........... 9

2.2.2 Contaminants of Ecological Concern $\ldots \ldots \ldots \ldots \ldots \ldots \ldots \ldots$

$3 \quad$ EXPOSURE ASSESSMENT $\ldots \ldots \ldots \ldots \ldots \ldots \ldots \ldots \ldots \ldots \ldots \ldots \ldots$

$3.1 \quad$ Identification of Exposure Pathways $\ldots \ldots \ldots \ldots \ldots \ldots \ldots \ldots \ldots \ldots \ldots$

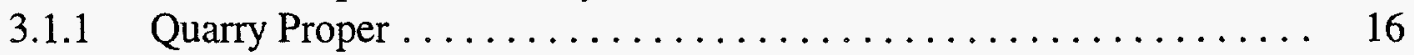

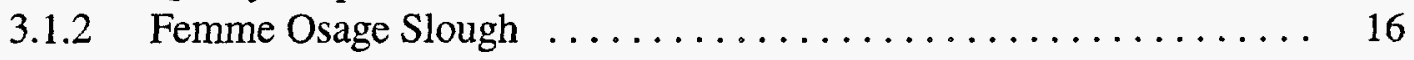

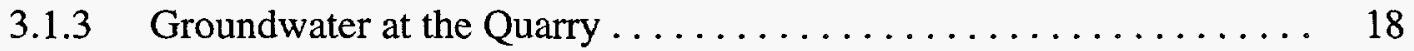

3.2 Estimation of Exposure Point Concentrations . . . . . . . . . . . . . 18

3.3 Estimation of Contaminant Intake by Humans $\ldots \ldots \ldots \ldots \ldots \ldots \ldots$

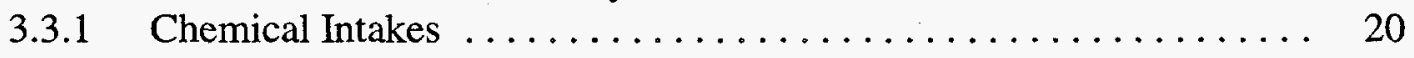

3.3.2 Radiological Intakes . . . . . . . . . . . . . . . . . 23

3.4 Estimation of Contaminant Intake by Biota $\ldots \ldots \ldots \ldots \ldots \ldots \ldots \ldots \ldots$

3.4.1 Ecological Receptors ....................... 25

3.4.2 Equations for Estimating Intake ................. 26

3.4.2.1 Chemical Uptake from Ingestion of Drinking Water . . . . 26

3.4.2.2 Chemical Uptake from Incidental Ingestion

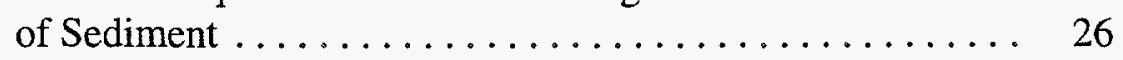

3.4.2.3 Chemical Uptake from Ingestion of Food . . . . . . . . . 27 


\section{CONTENTS (Cont.)}

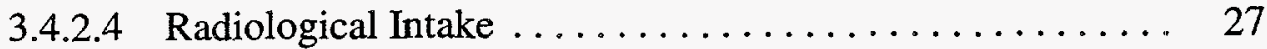

3.4.2.5 Exposure Factors ......................... 29

3.4.2.6 Model Assumptions ..................... 30

3.4.3 Estimation of Contaminant Doses .................. 30

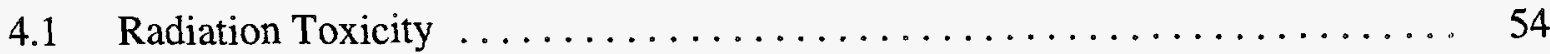

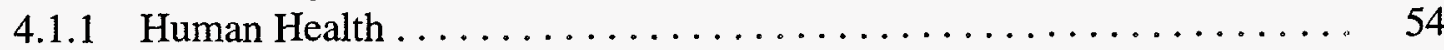

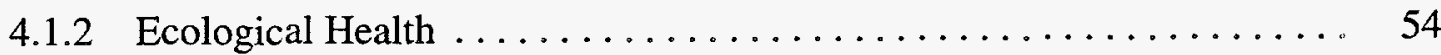

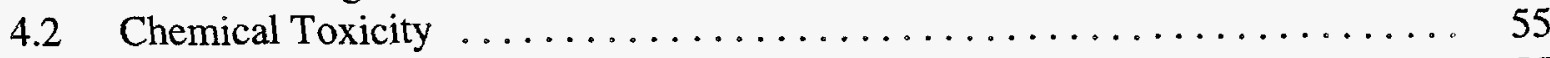

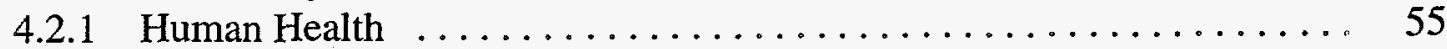

4.2 .2 Ecological Health $\ldots \ldots \ldots \ldots \ldots \ldots \ldots \ldots \ldots \ldots \ldots \ldots . \quad 57$

4.3 Methods for Evaluating Radiation and Chemical Toxicity

to Humans . . . . . . . . . . . . . . . . . . . . . . . . . . . . 58

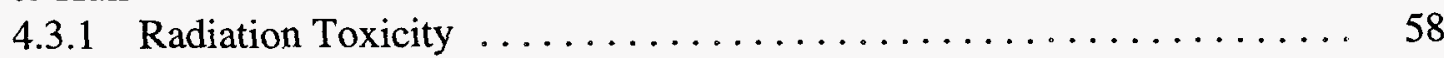

4.3.2 Chemical Toxicity $\ldots \ldots \ldots \ldots \ldots \ldots \ldots \ldots \ldots \ldots \ldots \ldots \ldots \ldots \ldots \ldots$

5 HUMAN HEALTH RISK CHARACTERIZATION $\ldots \ldots \ldots \ldots \ldots \ldots \ldots \ldots$

$5.1 \quad$ Risk Characterization Methodology $\ldots \ldots \ldots \ldots \ldots \ldots \ldots \ldots \ldots \ldots, 64$

5.1 .1 Radiological Risks ........................... 64

5.1 .2 Chemical Risks and Hazard Quotients .................. 65

5.1.2.1 Carcinogenic Risks ...................... 65

5.1.2.2 Hazard Quotients and Hazard Indices ............. 65

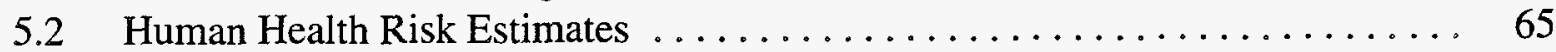

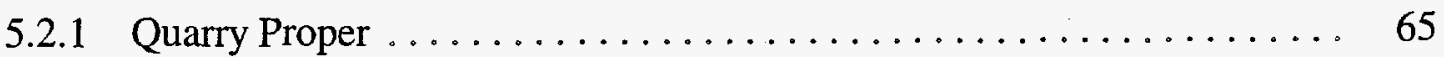

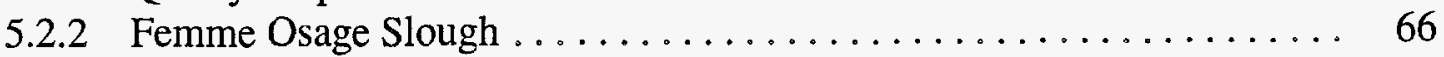

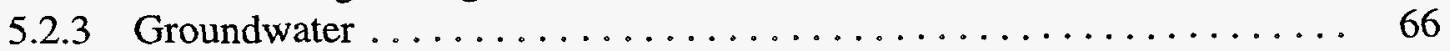

5.2.4 Multiple Exposure Pathways ...................... 67

5.3 Uncertainties Related to Risk Estimates . . . . . . . . . . . . . . . 67

5.3.1 Contaminants of Potential Concern ................... 67

5.3.2 Exposure Assessment ........................... 68

5.3 .3 Toxicity Assessment $\ldots \ldots \ldots \ldots \ldots \ldots \ldots \ldots \ldots \ldots \ldots \ldots \ldots \ldots \ldots$

5.3.4 Risk Characterization ......................... 69

6 ECOLOGICAL RISK ASSESSMENT $\ldots \ldots \ldots \ldots \ldots \ldots \ldots \ldots \ldots \ldots \ldots \ldots$

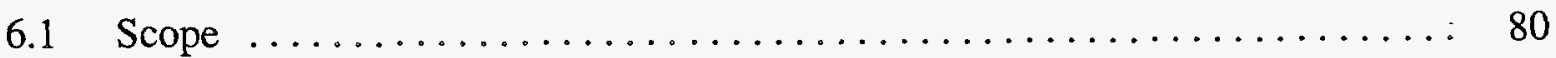

6.1 .1 Objectives ................................. 80

6.1 .2 Assessment Approach $\ldots \ldots \ldots \ldots \ldots \ldots \ldots \ldots \ldots \ldots \ldots \ldots, \quad 80$

6.1 .3 Risk Determination .......................... 81

6.2 Ecological Characterization $\ldots \ldots \ldots \ldots \ldots \ldots \ldots \ldots \ldots \ldots \ldots, 81$ 
6.3 Contaminants and Resources of Ecological Concern ............... 83

6.3.1 Media and Habitats of Concern $\ldots \ldots \ldots \ldots \ldots \ldots \ldots \ldots \ldots . . . \ldots 3$

6.3.2 Ecological Receptors and Exposure Pathways .............. 83

6.4 Effects and Exposure Assessments $\ldots \ldots \ldots \ldots \ldots \ldots \ldots \ldots \ldots \ldots . \ldots \ldots$

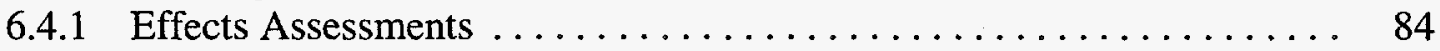

6.4.2 Exposure Assessments . ........................ 84

6.4.2.1 Small Mammal Tissue Concentrations .............. 84

6.4.2.2 Fish Tissue Concentrations ................... 85

6.4.2.3 Modeled Contaminant Intake ................ 86

6.5 Ecological Risk Characterization $\ldots \ldots \ldots \ldots \ldots \ldots \ldots \ldots \ldots \ldots \ldots . \ldots \ldots$

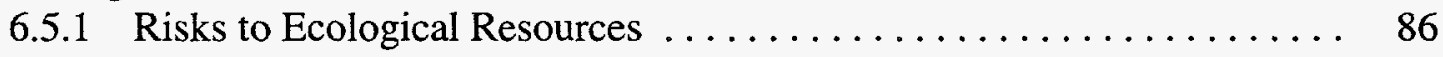

6.5.1.1 Ecological Effects Quotient $\ldots \ldots \ldots \ldots \ldots \ldots \ldots \ldots \ldots .86$

6.5.1.2 Weight of Evidence ....................... 88

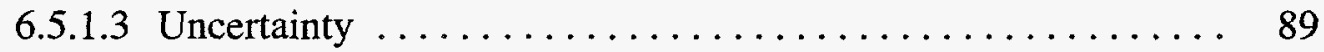

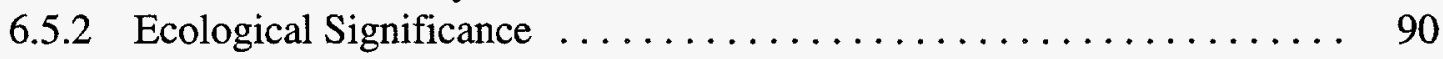

$7 \quad$ SUMMARY AND CONCLUSIONS $\ldots \ldots \ldots \ldots \ldots \ldots \ldots \ldots \ldots \ldots \ldots \ldots \ldots \ldots$

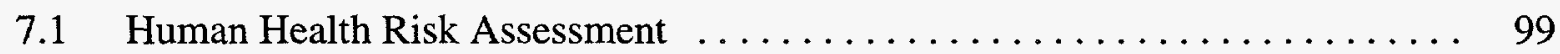

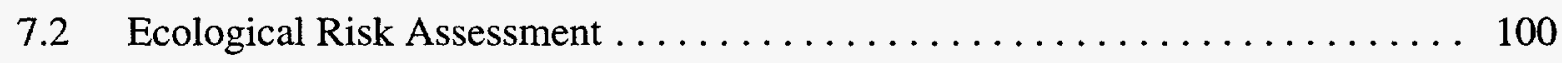

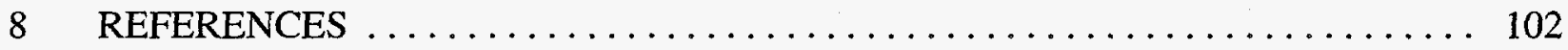

\section{FIGURES}

1.1 Area Surrounding the Weldon Spring Quarry $\ldots \ldots \ldots \ldots \ldots \ldots \ldots \ldots \ldots .2$

3.1 Conceptual Site Exposure Model $\ldots \ldots \ldots \ldots \ldots \ldots \ldots \ldots \ldots \ldots \ldots \ldots \ldots \ldots \ldots \ldots \ldots$

\section{TABLES}

2.1 Final List of Human Health Contaminants of Potential Concern

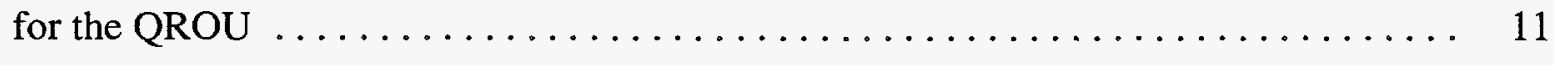

2.2 Screening Evaluation of Surface Water for the Identification of Contaminants of Ecological Concern $\ldots \ldots \ldots \ldots \ldots \ldots \ldots \ldots \ldots \ldots \ldots \ldots$

2.3 Screening Evaluation of Sediment for the Identification of 


\section{TABLES (Cont.)}

2.4 Final List of Contaminants of Ecological Concern for the QROU ........... 14

3.1 Human Receptors and Exposure Pathways for the QROU $\ldots \ldots \ldots \ldots \ldots \ldots$

3.2 Exposure Scenario Assumptions and Intake Parameters for the Current and Future Recreational Visitor $\ldots \ldots \ldots \ldots \ldots \ldots \ldots \ldots \ldots$

3.3 Exposure Point Concentrations and Estimated Chemical Contaminant

Intakes for a Recreational Visitor at the Quarry Proper ................

3.4 Exposure Point Concentrations and Estimated Radiological Contaminant

Intakes for a Recreational Visitor at the Quarry Proper ................

3.5 Exposure Point Concentrations and Estimated Contaminant Intakes

for a Recreational Visitor from Exposure to Surface Water and Sediment

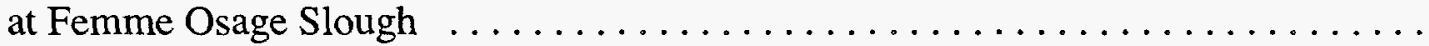

3.6 Exposure Point Concentrations and Estimated Contaminant Intakes

for Ingestion of Fish from Femme Osage Slough $\ldots \ldots \ldots \ldots \ldots \ldots \ldots$

3.7 Estimated Intakes of Uranium for a Hypothetical Future Resident . . . . . . . . .

3.8 Estimated Noncarcinogenic Intakes of Metal COPCs for a Hypothetical

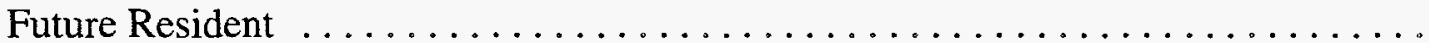

3.9 Estimated Noncarcinogenic Intakes of Nitroaromatic Compound COPCs

for a Hypothetical Future Resident $\ldots \ldots \ldots \ldots \ldots \ldots \ldots \ldots \ldots \ldots$

3.10 Estimated Carcinogenic Intakes of Nitroaromatic Compound COPCs

for a Hypothetical Future Resident

3.11 Species-Specific Exposure Factors for Ecological Receptors

Using the QROU

3.12 Estimated Contaminant Doses for the Mallard Duck Foraging

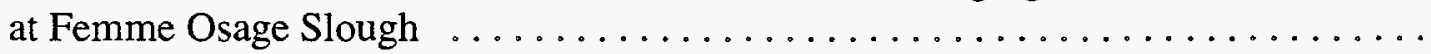

3.13 Estimated Contaminant Doses for the Great Blue Heron Foraging

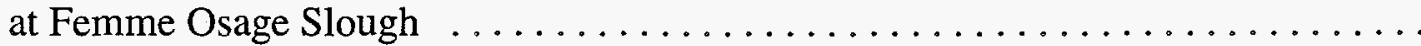

3.14 Estimated Contaminant Doses for the Bald Eagle Foraging at Femme Osage Slough 


\section{TABLES (Cont.)}

3.15 Estimated Contaminant Doses for the White-Tailed Deer Drinking from Femme Osage Slough and Little Femme Osage Creek ................ 52

3.16 Estimated Radiological Daily Dose Rates to Wildlife Receptors Ingesting Food, Surface Water, and Sediment from Femme Osage Slough

4.1 Radionuclide Slope Factors for the Ingestion, Inhalation, and External

Gamma Irradiation Pathways at the QROU

4.2 Toxicity Values of COPCs for Ingestion and Inhalation:

Potential Systemic Effects

4.3 Toxicity Values of COPCs for Ingestion and Inhalation:

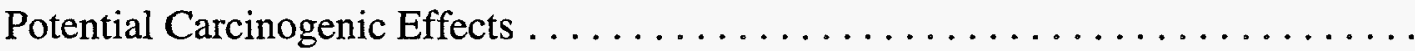

5.1 Estimated Radiological Carcinogenic Risks for a Future

Recreational Visitor at the Quarry Proper

5.2 Chemical Hazard Index and Carcinogenic Risks for a Future

Recreational Visitor at the Quarry Proper

5.3 Estimated Hazard Quotients and Carcinogenic Risks for a

Recreational Visitor Exposed to Surface Water and Sediments

at Femme Osage Slough

5.4 Estimated Hazard Quotients and Carcinogenic Risks for Ingestion

of Fish from Femme Osage Slough . .

5.5 Estimated Radiological Carcinogenic Risks for a Hypothetical

Future Resident

5.6 Estimated Chemical Carcinogenic Risks for a Hypothetical

Future Resident

5.7 Estimated Hazard Quotients for Metals for a Hypothetical

Future Resident

5.8 Estimated Hazard Quotients for Nitroaromatic Compounds

for a Future Hypothetical Resident

6.1 Whole-Body Radionuclide Concentrations in Tissue of Small Mammals

Collected from the QROU and Reference Locations 


\section{TABLES (Cont.)}

6.2 Benchmark Values Used for Estimating EEQs for Aquatic and Terrestrial Biota Utilizing Femme Osage Slough and Little Femme Osage Creek ..........

6.3 Estimated EEQs for Exposure of Fish and Aquatic Invertebrates to Surface Water and Sediments in Femme Osage Slough and Little Femme Osage Creek

$6.4 \quad$ Estimated EEQs for the Mallard $\ldots \ldots \ldots \ldots \ldots \ldots \ldots \ldots \ldots \ldots \ldots \ldots \ldots \ldots$

6.5 Estimated EEQs for the Great Blue Heron $\ldots \ldots \ldots \ldots \ldots \ldots \ldots \ldots \ldots$

6.6 Estimated EEQs for the Bald Eagle $\ldots \ldots \ldots \ldots \ldots \ldots \ldots \ldots \ldots \ldots \ldots \ldots \ldots$

6.7 Estimated EEQs for the White-Tailed Deer $\ldots \ldots \ldots \ldots \ldots \ldots \ldots \ldots \ldots$

7.1 Summary of Human Health Risk Estimates for the Quarry Area ............ 101 


\section{NOTATION}

The following is a list of the acronyms, initialisms, and abbreviations (including units of measure) used in this document. Some acronyms used in tables or equations only are defined in the respective tables or equations.

\section{ACRONYMS, INITIALISMS, AND ABBREVIATIONS}

\section{General}

\begin{tabular}{|c|c|}
\hline $\mathrm{ADD}$ & applied daily dose \\
\hline AWQC & ambient water quality criteria \\
\hline BRA & Baseline Risk Assessment \\
\hline CERCLA & $\begin{array}{l}\text { Comprehensive Environmental Response, Compensation, and Liability } \\
\text { Act of } 1980 \text {, as amended }\end{array}$ \\
\hline CFR & Code of Federal Regulations \\
\hline COEC & contaminant of ecological concern \\
\hline $\mathrm{COPC}$ & contaminant of potential concern (for human health) \\
\hline DCF & dose conversion factor \\
\hline DOE & U.S. Department of Energy \\
\hline EEQ & ecological effects quotient \\
\hline EPA & U.S. Environmental Protection Agency \\
\hline EPC & exposure point concentration \\
\hline FS & feasibility study \\
\hline HEAST & Health Effects Assessment Summary Tables \\
\hline IAEA & International Atomic Energy Agency \\
\hline ICRP & International Commission on Radiological Protection \\
\hline IRS & Integrated Risk Information System (database) \\
\hline $\mathrm{LC}_{50}$ & median concentration lethal to $50 \%$ of the population \\
\hline LOAEL & lowest-observed-adverse-effect level \\
\hline NCRP & National Council on Radiation Protection and Measurements \\
\hline NOAEL & no-observed-adverse-effect level \\
\hline NPL & National Priorities List \\
\hline QROU & quarry residuals operable unit \\
\hline $\mathrm{RfC}$ & reference concentration \\
\hline RfD & reference dose \\
\hline RI & remedial investigation \\
\hline ROD & Record of Decision \\
\hline UCL & $95 \%$ upper confidence limit of the arithmetic average \\
\hline VP9 & Vicinity Property 9 \\
\hline
\end{tabular}


Chemical Compounds

$\begin{array}{ll}\mathrm{CaCO}_{3} & \text { calcium carbonate } \\ \text { 2,4-DNT } & \text { 2,4-dinitrotoluene } \\ \text { 2,6-DNT } & 2,6 \text {-dinitrotoluene } \\ \text { PAH } & \text { polycyclic aromatic hydrocarbon } \\ \text { PCB } & \text { polychlorinated biphenyl } \\ \text { SVOC } & \text { semivolatile organic compound } \\ 1,3,5-\mathrm{TNB} & 1,3,5 \text {-trinitrobenzene } \\ 2,4,6-\mathrm{TNT} & 2,4,6 \text {-trinitrotoluene } \\ \text { VOC } & \text { volatile organic compound }\end{array}$

UNITS OF MEASURE

$\begin{array}{ll}\mathrm{cm} & \text { centimeter(s) } \\ \mathrm{cm}^{2} & \text { square centimeter(s) } \\ \mathrm{cm}^{3} & \text { cubic centimeter(s) } \\ \mathrm{d} & \text { day(s) } \\ \mathrm{dL} & \text { deciliter(s) } \\ \mathrm{ft} & \text { foot (feet) } \\ \mathrm{g} & \text { gram(s) } \\ \mathrm{h} & \text { hour(s) } \\ \mathrm{ha} & \text { hectare(s) } \\ \mathrm{kg} & \text { kilogram(s) } \\ \mathrm{km} & \text { kilometer(s) } \\ \mathrm{L} & \text { liter(s) } \\ \mu \mathrm{g} & \text { microgram(s) } \\ \mu \mathrm{m} & \text { micrometer(s) } \\ \mu \mathrm{R} & \text { microroentgen(s) }\end{array}$

$\begin{array}{ll}\mathrm{m} & \text { meter(s) } \\ \mathrm{m}^{3} & \text { cubic meter(s) } \\ \mathrm{mg} & \text { milligram(s) } \\ \mathrm{mi} & \text { mile(s) } \\ \mathrm{min} & \text { minute(s) } \\ \mathrm{mL} & \text { milliliter(s) } \\ \mathrm{mR} & \text { milliroentgen(s) } \\ \mathrm{mrem} & \text { millirem(s) } \\ \mathrm{pCi} & \text { picocurie(s) } \\ \mathrm{ppb} & \text { part(s) per billion } \\ \mathrm{ppm} & \text { part(s) per million } \\ \mathrm{rad} & \text { radiation absorbed dose(s) } \\ \mathrm{s} & \text { second(s) } \\ \mathrm{wt} & \text { weight } \\ \mathrm{yr} & \text { year(s) }\end{array}$




\section{ENGLISH/METRIC AND METRIC/ENGLISH EQUIVALENTS}

The following table lists the appropriate equivalents for English and metric units.

\begin{tabular}{|c|c|c|}
\hline Multiply & By & To Obtain \\
\hline \multicolumn{3}{|l|}{ English/Metric Equivalents } \\
\hline $\begin{array}{l}\text { acres } \\
\text { cubic feet }\left(\mathrm{ft}^{3}\right) \\
\text { cubic yards }\left(\mathrm{yd}^{3}\right) \\
\text { degrees Fahrenheit }\left({ }^{\circ} \mathrm{F}\right)-32 \\
\text { feet }(\mathrm{ft}) \\
\text { gallons (gal) } \\
\text { gallons (gal) } \\
\text { inches (in.) } \\
\text { miles (mi) } \\
\text { pounds (lb) } \\
\text { short tons (tons) } \\
\text { short tons (tons) } \\
\text { square feet }\left(\mathrm{ft}^{2}\right) \\
\text { square miles }\left(\mathrm{mi}^{2}\right) \\
\text { square yards }\left(\mathrm{yd}^{2}\right) \\
\text { yards (yd) }\end{array}$ & $\begin{array}{l}0.4047 \\
0.02832 \\
0.7646 \\
0.5555 \\
0.3048 \\
3.785 \\
0.003785 \\
2.540 \\
1.609 \\
0.4536 \\
907.2 \\
0.9072 \\
0.09290 \\
2.590 \\
0.8361 \\
0.9144 \\
-\end{array}$ & $\begin{array}{l}\text { hectares }(\mathrm{ha}) \\
\text { cubic meters }\left(\mathrm{m}^{3}\right) \\
\text { cubic meters }\left(\mathrm{m}^{3}\right) \\
\text { degrees Celsius }\left({ }^{\circ} \mathrm{C}\right) \\
\text { meters }(\mathrm{m}) \\
\text { liters }(\mathrm{L}) \\
\text { cubic meters }\left(\mathrm{m}^{3}\right) \\
\text { centimeters }(\mathrm{cm}) \\
\text { kilometers }(\mathrm{km}) \\
\text { kilograms }(\mathrm{kg}) \\
\text { kilograms }(\mathrm{kg}) \\
\text { metric tons }(\mathrm{t}) \\
\text { square meters }\left(\mathrm{m}^{2}\right) \\
\text { square kilometers }\left(\mathrm{km}^{2}\right) \\
\text { square meters }\left(\mathrm{m}^{2}\right) \\
\text { meters }(\mathrm{m})\end{array}$ \\
\hline \multicolumn{3}{|l|}{ Metric/English Equivalents } \\
\hline $\begin{array}{l}\text { centimeters }(\mathrm{cm}) \\
\text { cubic meters }\left(\mathrm{m}^{3}\right) \\
\text { cubic meters }\left(\mathrm{m}^{3}\right) \\
\text { cubic meters }\left(\mathrm{m}^{3}\right) \\
\text { degrees Celsius }\left({ }^{\circ} \mathrm{C}\right)+17.78 \\
\text { hectares }(\mathrm{ha}) \\
\text { kilograms }(\mathrm{kg}) \\
\text { kilograms }(\mathrm{kg}) \\
\text { kilometers }(\mathrm{km}) \\
\text { liters }(\mathrm{L}) \\
\text { meters }(\mathrm{m}) \\
\text { meters }(\mathrm{m}) \\
\text { metric tons }(\mathrm{t}) \\
\text { square kilometers }\left(\mathrm{km}^{2}\right) \\
\text { square meters }\left(\mathrm{m}^{2}\right) \\
\text { square meters }\left(\mathrm{m}^{2}\right)\end{array}$ & $\begin{array}{l}0.3937 \\
35.31 \\
1.308 \\
264.2 \\
1.8 \\
2.471 \\
2.205 \\
0.001102 \\
0.6214 \\
0.2642 \\
3.281 \\
1.094 \\
1.102 \\
0.3861 \\
10.76 \\
1.196 \\
\end{array}$ & $\begin{array}{l}\text { inches (in.) } \\
\text { cubic feet }\left(\mathrm{ft}^{3}\right) \\
\text { cubic yards }\left(\mathrm{yd}^{3}\right) \\
\text { gallons (gal) } \\
\text { degrees Fahrenheit }\left({ }^{\circ} \mathrm{F}\right) \\
\text { acres } \\
\text { pounds (lb) } \\
\text { short tons (tons) } \\
\text { miles (mi) } \\
\text { gallons (gal) } \\
\text { feet }(\mathrm{ft}) \\
\text { yards (yd) } \\
\text { short tons (tons) } \\
\text { square miles }\left(\mathrm{mi}^{2}\right) \\
\text { square feet }\left(\mathrm{ft}^{2}\right) \\
\text { square yards }\left(\mathrm{yd}^{2}\right)\end{array}$ \\
\hline
\end{tabular}




\section{INTRODUCTION}

The U.S. Department of Energy (DOE) is conducting cleanup activities at the Weldon Spring site, located in St. Charles County, Missouri, about $48 \mathrm{~km}$ (30 mi) west of St. Louis. Cleanup of the site consists of several integrated components. The quarry residuals operable unit (QROU), consisting of the Weldon Spring quarry and its surrounding area (Figure 1.1), is one of four operable units being evaluated. In accordance with requirements of the Comprehensive Environmental Response, Compensation, and Liability Act (CERCLA), as amended, DOE is conducting a remedial investigation/feasibility study (RI/FS) to determine the proper response to address various contaminated media that constitute the QROU. Specifically, the operable unit consists of the following areas and media: the residual material remaining at the Weldon Spring quarry after removal of the pond water and the bulk waste; groundwater underlying the quarry and surrounding area; and other media located in the surrounding vicinity of the quarry, including surface water and sediment at Femme Osage Slough, Little Femme Osage Creek, and Femme Osage Creek.

An initial evaluation of conditions at the quarry area identified remaining data requirements needed to support the conceptual site exposure and hydrogeological models. These data requirements are discussed in the RIFS work plan issued in January 1994 (DOE 1994a). Soil contamination located at a property adjacent to the quarry, referred to as Vicinity Property 9 (VP9), was originally part of the scope of the QROU, as discussed in the work plan. However, a decision was subsequently made to remediate this vicinity property as part of cleanup activities for the chemical plant operable unit, as provided for in the Record of Decision (ROD). Remediation of VP9 was completed in early 1996 (Valett 1997). Hence, this baseline risk assessment (BRA) does not address VP9.

\subsection{SCOPE OF THE BASELINE RISK ASSESSMENT}

This BRA documents the calculations performed to determine if exposure to contamination present at the quarry area poses potentially unacceptable risks to human health or the environment. Risk scenarios for each area of concern or exposure unit at the quarry area were established in the work plan, and a recreational use scenario was identified for the entire operable unit. The potential for exposure or contact with groundwater at the quarry area is unlikely given current and expected future land use. For ecological resources, the principal exposure scenarios are associated with the aquatic habitats at Femme Osage Slough and the lowermost reach of Little Femme Osage Creek.

\subsection{OBJECTIVES OF THE BASELINE RISK ASSESSMENT}

This BRA provides a combined baseline assessment of potential human health and ecological impacts for the QROU. The evaluation serves as an estimate of the magnitude of potential 


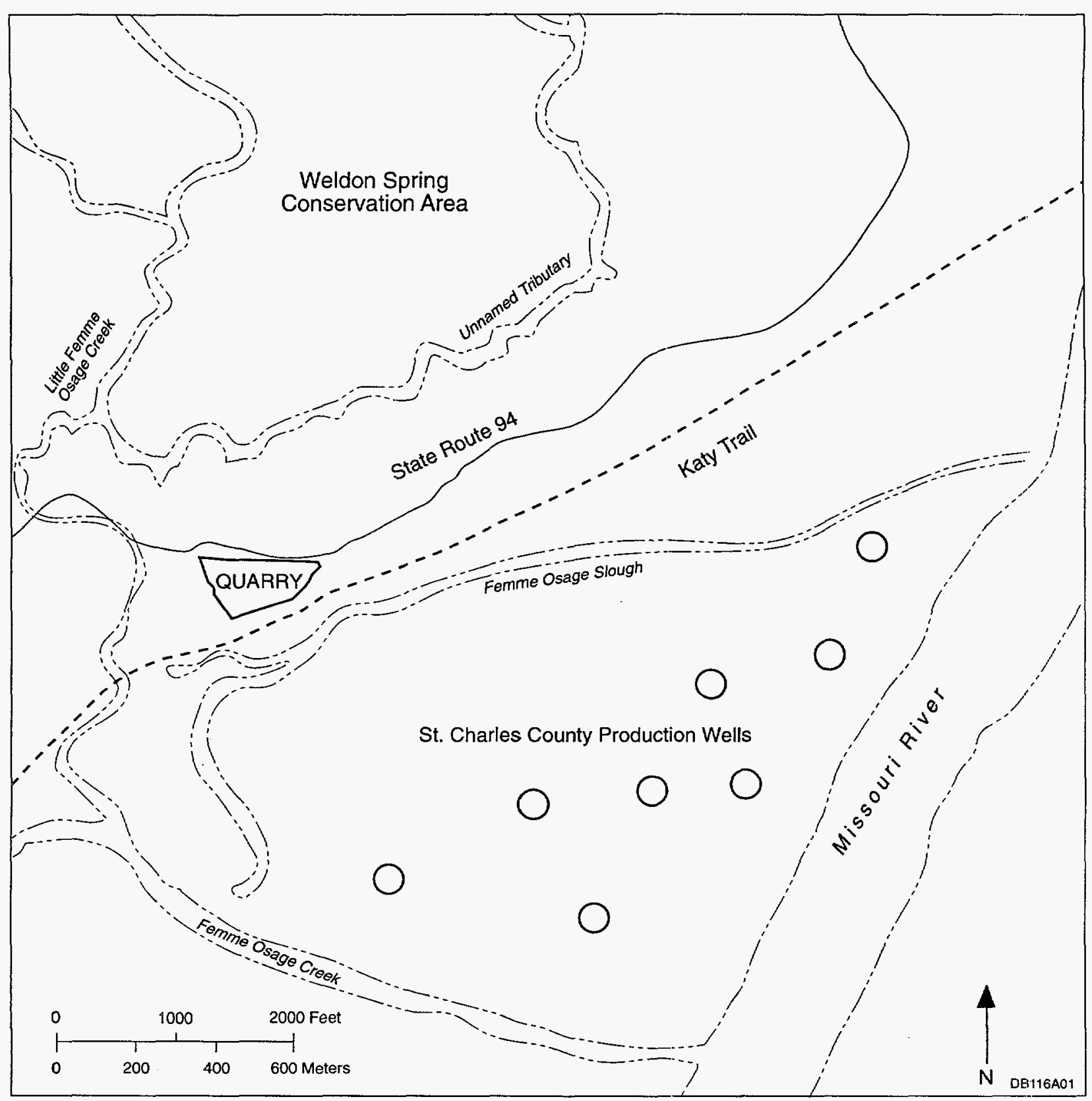

FIGURE 1.1 Area Surrounding the Weldon Spring Quarry 
health risks and environmental impacts that would be associated with QROU contaminants if no remedial action were taken. In addition, the risk estimate presented in this BRA would also serve as a baseline against which protectiveness of cleanup alternatives discussed in upcoming RI/FS reports could be compared.

\subsection{ORGANIZATION OF THE REPORT}

Data utilized in this report have been presented in either the work plan (DOE 1994a) or the RI report (MK-Ferguson Company and Jacobs Engineering Group 1997). The remainder of this report is organized as follows:

- Chapter 2 - Identification of contaminants of potential concern and a brief discussion of the associated data;

- Chapter 3 - Presentation of the exposure assessment, including calculations of exposure point concentrations, intakes, and doses;

- Chapter 4 - Brief discussion of the toxicity of the contaminants of concern and associated toxicity values;

- Chapter 5 - Human health risk characterization;

- Chapter 6 - Ecological risk assessment;

- Chapter 7 - Summary and conclusions; and

- Chapter 8 - List of references cited. 


\section{IDENTIFICATION OF CONTAMINANTS OF CONCERN}

General background information on the QROU, including origin of contamination, is discussed in the RI/FS work plan (DOE 1994a); detailed descriptions of data collection efforts and data summaries are presented in the RI report (MK-Ferguson Company and Jacobs Engineering Group 1997).

Because of the results of evaluations to date, the areas and media that are the focus of this risk assessment are (1) residual soil contamination at the quarry proper; (2) surface water and sediment contamination at Femme Osage Slough, Little Femme Osage Creek, and Femme Osage Creek; and (3) groundwater contamination beneath the quarry and surrounding area. The discussions in Section 2.1 are organized according to the specific areas of exposure and the media of concern for these areas. The data evaluation procedure used in this BRA is discussed in Section 2.2.

\subsection{DATA CONSIDERATIONS}

Monitoring and characterization samples collected from the various media present at the quarry area were analyzed for radiological and chemical parameters. These data were obtained from November 1987 through August 1996. Samples were also collected from what were considered to be background areas in order to delineate naturally occurring levels of metals. A comparison of concentrations of naturally occurring constituents at the quarry area with background levels is provided in the RI. A brief summary of characterization results for each medium is provided in Sections 2.1.1 through 2.1.4.

\subsubsection{Quarry Proper}

Soil samples were collected in seven areas of the quarry proper. Samples were also collected from fractures in the quarry walls and floors. The primary contaminants in the quarry are radionuclides, with higher levels of contamination in fractures and depressions in the quarry floor. Radionuclides that were detected at concentrations above background include isotopes of radium, thorium, and uranium. For the chemical constituents, a few metals were also detected at concentrations above background. These metals were aluminum, calcium, magnesium, selenium, silver, and zinc. Nitroaromatic compounds and polychlorinated biphenyls (PCBs) were detected in isolated areas of the quarry proper, but concentrations were low (e.g., less than $10 \mathrm{ppm}$ ). Polycyclic aromatic hydrocarbons (PAHs) were also detected in some samples, at a maximum concentration of $0.43 \mathrm{ppm}$; the source of this contamination is considered to be surface water runoff from nearby asphalt areas used for equipment access and lubricants from equipment operating in the quarry.

In addition to analysis of discrete soil samples, exposure-rate measurements were taken at

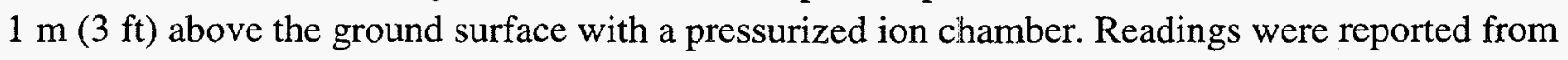


eight locations in the quarry proper; measurements ranged from 8.5 to $34 \mu \mathrm{R} / \mathrm{h}$, with an average exposure level of $17 \mu \mathrm{R} / \mathrm{h}$. Monitoring data for radioactive air particulates and radon at the quarry area have been at background levels.

Surface water quality in the quarry pond has been evaluated to determine residual contaminant levels. Three samples were collected and analyzed after September 1996; uranium was the only contaminant measured in the quarry pond. Other constituents were not detected or were detected at trace levels. Total uranium concentrations ranged from 490 to $540 \mathrm{pCi} / \mathrm{L}$.

\subsubsection{Femme Osage Slough}

\subsubsection{Sediment}

Analysis of radiological parameters in sediment samples from Femme Osage Slough included measurements of concentrations of isotopic radium, thorium, and uranium. Chemical parameters measured included concentrations of metals, inorganic anions, volatile organic compounds (VOCs), semivolatile organic compounds (SVOCs), PCBs, pesticides, and nitroaromatic compounds.

Of the radionuclides, only radium-228 and uranium-238 were detected at concentrations slightly elevated above background levels. For the chemical constituents, concentrations of several metals and inorganic anions exceeded background concentrations - including chloride, fluoride, sulfate, aluminum, beryllium, cadmium, calcium, chromium, copper, iron, lithium, magnesium, manganese, mercury, molybdenum, nickel, potassium, selenium, sodium, strontium, and vanadium. Chemical analyses also indicated low levels of nitroaromatic compounds, ranging from 0.007 to $0.14 \mathrm{ppm}$. VOCs and SVOCs were generally below method detection limits for all sediment samples. A few common laboratory contaminants were detected at levels below $1 \mathrm{ppm}$; the concentrations were within the range allowed for laboratory contamination (U.S. Environmental Protection Agency [EPA] 1989a). No pesticides or PCBs were detected in any of the samples.

\subsubsection{Surface Water}

Surface water in Femme Osage Slough has been sampled and analyzed for radium and thorium isotopes, total uranium, metals, inorganic anions, VOCs, SVOCs, PCBs, pesticides, and nitroaromatic compounds. Levels of uranium were significantly elevated over background concentrations; the average concentration detected in the slough was $64 \mathrm{pCi} / \mathrm{L}$. Several metals were detected above background concentrations - including aluminum, arsenic, chromium, lead, iron, manganese, nickel, strontium, sodium, and zinc. Sulfate and nitrate were also elevated over background concentrations. Nitroaromatic compounds and organics were not detected. 


\subsubsection{Fish}

Fish were sampled at Femme Osage Slough from 1987 to 1993. Fish were also sampled from two lakes in the Busch Conservation Area (Lakes 33 and 37) that are not influenced by site contaminants. The constituent concentrations detected in these lake samples were used as background levels for comparison with concentrations detected in the Femme Osage Slough samples. Fish were collected annually, depending on the species, size, and number of fish available. The fish community in Femme Osage Slough is different from that in the Busch lakes because of the influence of the Missouri River on the slough. The water level in the slough is controlled by a pipe with a valve that normally is left open, allowing fish to move between the river and the slough. As a result, fish species routinely found in big river habitats, such as the Missouri River, are found in the slough. Species sampled from the slough included white and black crappie; largemouth bass; sunfish; and bottom feeders, including bigmouth buffalo, yellow bullhead, and common carp.

Fillet, fish-scale, and whole-body samples of fish were analyzed for radioactive and chemical constituents - including uranium, radium, thorium, arsenic, lead, and mercury. No radium or thorium was measured at a level above the respective detection limit in any of the samples. Low concentrations of uranium and metals were detected.

\subsubsection{Femme Osage Creek and Little Femme Osage Creek}

\subsubsection{Sediment}

Sediment samples collected from five locations along Little Femme Osage Creek were analyzed for isotopic radium, thorium, uranium, other metals, inorganic anions, and nitroaromatic compounds. In general, contaminant concentrations were lower in Little Femme Osage Creek sediments than in the sediments of Femme Osage Slough. The only exception was antimony, which was detected in creek sediments at an average concentration of $17 \mathrm{mg} / \mathrm{kg}$. Antimony was not detected in slough sediments. The only nitroaromatic compound in the creek sediment was a one-time detection of 2,4-dinitrotoluene upgradient of the quarry at a concentration of $0.0024 \mathrm{mg} / \mathrm{kg}$.

\subsubsection{Surface Water}

Surface water samples were collected from six locations in Little Femme Osage Creek and one location in Femme Osage Creek. Radiological and chemical parameters that were analyzed included concentrations of isotopic radium and thorium, uranium, metals, inorganic anions, and nitroaromatic compounds. Contaminant concentrations in creek water were generally lower than the concentrations in the surface water of Femme Osage Slough, except for nitroaromatic compounds. Low levels of several nitroaromatic compounds were detected upgradient of the quarry; concentrations ranged between 0.011 and $0.067 \mu \mathrm{g} / \mathrm{L}$. 
Because levels of radiological and chemical constituents in Little Femme Osage Creek sediments and surface water are generally lower than those in slough sediments, the creek was not evaluated further in this BRA. Risk results for the slough bound the risks for Little Femme Osage Creek. Nitroaromatic compounds detected in creek surface water were included in the analysis of the slough.

\subsubsection{Groundwater}

Groundwater samples have been collected and routinely analyzed from $36 \mathrm{DOE}$ monitoring wells, four St. Charles County monitoring wells, and eight St. Charles County production wells. Radioactive and chemical constituent analyses have been conducted for isotopic radium, thorium, and uranium; metals; inorganic anions; nitroaromatic compounds; VOCs; SVOCs; PCBs; and pesticides.

The primary contaminants in groundwater are uranium and nitroaromatic compounds. The highest uranium concentrations were measured in a well along the southern rim of the quarry (monitoring well MW-1004) and in a well in the alluvium north of Femme Osage Slough near VP9 (MW-1008). Nitroaromatic compounds have been detected at concentrations higher than 1 part per billion (ppb) in six groundwater wells. The highest concentrations of nitroaromatic compounds primarily 1,3,5-trinitrobenzene (1,3,5-TNB), 2,4,6-trinitrotoluene (2,4,6-TNT), 2,4-dinitrotoluene (2,4-DNT), and 2,6-dinitrotoluene (2,6-DNT) - were along the eastern rim of the quarry (MW-1002) and in the alluvium east-southeast of the quarry (MW-1006). Contamination has been detected primarily north of Femme Osage Slough. Uranium concentrations measured within the bedrock north of the quarry and in the alluvium south of the slough are at or slightly above naturally occurring levels. Slightly higher levels of uranium have been detected in one well located south of the slough (RMW-2); the maximum concentration detected was $10 \mathrm{pCi} / \mathrm{L}$, which is within the range of concentrations detected in the background wells. Data collected since removal of the bulk waste from the quarry are similar to the historic data. A sharp increase in concentrations of nitroaromatic compounds was observed in some of the quarry rim wells at the beginning of bulk waste removal, but levels decreased as remediation progressed. The same trend was not observed for uranium.

Measured concentrations of radium and thorium isotopes have generally been at or slightly above naturally occurring concentrations. Concentrations of several metals and inorganic anions were above background concentrations - including sulfate, chloride, aluminum, barium, cadmium, calcium, chromium, cobalt, copper, manganese, mercury, nickel, potassium, sodium, thallium, vanadium, and zinc. A few VOCs that are common laboratory contaminants were detected, but the concentrations were within the range allowed for laboratory contamination. Several organic compounds were detected in a number of wells in the September 1987 sampling round but were never detected again in subsequent sampling rounds. These data are suspected to be a result of laboratory contamination, but it is not possible to verify or validate data collected in 1987 because of the lack of documentation regarding quality assurance/quality control. 
Measured concentrations of radioactive and chemical contaminants in wells at the St. Charles County well field are at background levels.

\subsection{DATA EVALUATION}

Site characterization data collected to date were evaluated for appropriateness of use in the risk assessment. The EPA guidelines for data evaluation (EPA 1989a) were followed in determining the contaminants of potential concern for the following media and areas: soil from the quarry proper; sediment, surface water, and fish tissue from Femme Osage Slough; and groundwater from site monitoring wells.

In accordance with EPA (1989a) guidance, the following data evaluation steps were applied to identify the contaminants of potential concern for each medium (e.g., soil or groundwater) and to gather the subset of data for exposure quantification:

1. Evaluation of analytical methods used and consideration of data qualifiers, results of control blank samples, sample quantitation limits, and detection frequency;

2. Evaluation of the significance of all detected compounds;

3. Comparison of potential site-related contamination with background levels;

4. Screening of certain chemicals classified as essential nutrients on the basis of their concentration and potential toxicity; and

5. Performance of a concentration/toxicity screen to limit the number of contaminants carried through the risk assessment to those with the most potential for causing human health risks and/or adverse ecological effects.

The first three steps of the data evaluation process apply to both radionuclides and chemicals and were also performed in the RI as part of the evaluation to determine the nature and extent of contamination. The final two steps apply to chemical contaminants. A concentration/toxicity screen was not performed for the human health assessment, so the number of contaminants carried through the risk assessment was not limited.

Samples from all media were analyzed according to EPA methods considered to yield qualitative and quantitative results suitable for risk assessment purposes. Data qualifiers were used by the analytical laboratory in reporting the results in order to provide an interpretation of the data from an analytical standpoint. EPA guidance recommends that a chemical be eliminated from consideration as a potential site contaminant if that chemical is present at a concentration no more than 10 times the level of a common laboratory contaminant in the associated control blank 
sample(s). Several organic constituents were eliminated from further evaluation because (1) they were present in laboratory blanks or (2) they were common laboratory contaminants present at low levels. However, chemical concentrations reported as "estimated" due to detection at levels lower than the contract-required detection limit were included in data analyses.

For each area and medium evaluated, parameters with a detection frequency of zero were eliminated from further consideration as potential site contaminants. Then, concentrations of remaining parameters were compared with media-specific background levels of naturally occurring constituents.

Statistical comparisons were performed to identify naturally occurring constituents present at the QROU at concentrations greater than background. A more detailed discussion on background comparisons is provided in the RI (MK-Ferguson Company and Jacobs Engineering Group 1997). The constituents that were determined to be present at levels greater than background were then subjected to the remaining steps of the screening process to identify contaminants of potential concern (COPCs) for human health or contaminants of ecological concern (COECs), as discussed below.

\subsubsection{Human Health Contaminants of Potential Concern}

The next step in the screening was to identify the human health COPCs. The following substances were eliminated from consideration because they are essential human nutrients or constituents of low toxicity: calcium, chloride, fluoride, iron, magnesium, potassium, and sodium.

Lithium, sulfate, and bromide were screened from consideration as COPCs on the basis of their low toxicity, widespread presence in the natural environment, and low to moderate site concentrations. Lithium is present in the daily human diet at a level of about $2 \mathrm{mg}$ (Venugopal and Luckey 1978) and is safely used as a psychiatric drug at concentrations of approximately $1 \mathrm{~g} / \mathrm{d}$. Sulfate exhibits low toxicity in humans but has been shown to have laxative effects at water concentrations of $630 \mathrm{mg} / \mathrm{L}$ or greater (Chien et al. 1968). On the basis of this information, it was concluded that levels of these substances in site media are considerably lower than those that would lead to adverse health effects in humans.

The EPA has not yet issued quantitative toxicity values for aluminum, cobalt, or lead. These substances were retained as COPCs so their potential toxic effects could be considered further.

The data evaluation process for radionuclides resulted in the identification of radium-226, radium-228, thorium-228, thorium-230, thorium-232, and uranium-238 as COPCs for soils from the quarry proper. For the other media (i.e., Femme Osage Slough surface water and sediment, and groundwater), only uranium was identified as a COPC. Other radionuclides were screened from 
consideration because they are present at near-background concentrations. Table 2.1 provides a final list of human health COPCs for the QROU.

\subsubsection{Contaminants of Ecological Concern}

The screening process for COECs involved comparing measured media concentrations to background concentrations and ecological regulatory standards or screening values. Backglound values used in this screening process were the surface water and sediment concentrations reported for Femme Osage Creek above its confluence with Little Femme Osage Creek. Regulatory and screening values used in the process included the EPA (1986) ambient water quality criteria (AWQC), EPA (1996) ecotox threshold values, state of Missouri water quality standards (Missouri Department of Natural Resources 1992), and data from the scientific literature, including U.S. Fish and Wildlife Service toxicity profiles (e.g., Eisler 1988). Tables 2.2 and 2.3 present the screening results for surface water and sediments, respectively. The final list of contaminants of ecological concern is presented in Table 2.4 .

Potential surface water contaminants eliminated from inclusion as COECs included copper and nickel (maximum reported concentrations were less than the screening and background levels); fluoride, nitrate, arsenic, mercury, zinc, and several nitroaromatic compounds (maximum reported concentrations were less than the screening levels); and antimony, magnesium, and thallium (maximum concentrations were below background levels).

Sediment-related contaminants eliminated as COECs included chromium and copper (maximum concentrations were less than the screening levels) and thallium (maximum concentration was less than the background level). No screening values were available for three nitroaromatic compounds (2,4-DNT, 2,6-DNT, and nitrobenzene), and, therefore, these compounds were retained as sediment COECs (Table 2.4).

No soil contaminants were identified as COECs, primarily because of the absence of contamination in terrestrial habitats. No soil contamination occurs along the slough, Femme Osage Creek, and Little Femme Osage Creek. At the quarry proper, soil contamination is limited to residual materials remaining deep within the cracks and crevices in the quarry walls and floor, and these materials are not considered to represent a significant exposure route to ecological resources. In addition, the overall absence of suitable habitat within the quarry precludes more than very occasional use of the quarry proper by area wildlife. 
TABLE 2.1 Final List of Human Health Contaminants of Potential Concern for the QROU

\begin{tabular}{|c|c|c|c|c|}
\hline \multirow[b]{2}{*}{ Contaminant } & \multirow{2}{*}{$\begin{array}{c}\text { Quarry Proper } \\
\text { Soil and } \\
\text { Fractures } \\
\end{array}$} & \multicolumn{2}{|c|}{ Femme Osage Slough } & \multirow{2}{*}{$\begin{array}{c}\text { Quarry } \\
\text { Groundwater }\end{array}$} \\
\hline & & Surface Water & Sediment & \\
\hline \multicolumn{5}{|l|}{ Radionuclides } \\
\hline Radium-226 & + & - & - & - \\
\hline Radium-228 & + & - & - & - \\
\hline Thorium-228 & + & - & - & - \\
\hline Thorium-230 & + & - & - & - \\
\hline Thorium-232 & + & - & - & - \\
\hline Uranium & + & + & + & + \\
\hline \multicolumn{5}{|l|}{ Metals } \\
\hline Aluminum & + & + & + & + \\
\hline Antimony & - & - & + & - \\
\hline Arsenic & - & + & - & - \\
\hline Barium & - & - & - & + \\
\hline Beryllium & - & - & + & - \\
\hline Cadmium & - & - & + & + \\
\hline Chromium & - & + & + & + \\
\hline Cobalt & - & - & - & + \\
\hline Copper & - & - & + & + \\
\hline Lead & - & + & - & - \\
\hline Manganese & - & + & + & + \\
\hline Mercury & - & - & + & + \\
\hline Molybdenum & - & - & + & - \\
\hline Nickel & - & + & + & + \\
\hline Selenium & + & - & + & - \\
\hline Silver & + & + & - & - \\
\hline Strontium & - & + & + & - \\
\hline Thallium & - & - & - & + \\
\hline Uranium & + & + & + & + \\
\hline Vanadium & - & - & + & + \\
\hline Zinc & + & + & - & + \\
\hline \multicolumn{5}{|c|}{ Organic compounds } \\
\hline $1,3,5-\mathrm{TNB}$ & + & + & + & + \\
\hline 1,3-DNB & + & - & + & + \\
\hline $2,4,6-\mathrm{TNT}$ & + & + & + & + \\
\hline $2,4 \mathrm{DNT}$ & + & + & + & + \\
\hline 2,6-DNT & + & + & + & + \\
\hline Nitrobenzene & + & - & + & - \\
\hline PCBs & + & - & - & - \\
\hline PAHs & + & - & - & - \\
\hline
\end{tabular}


TABLE 2.2 Screening Evaluation of Surface Water for the Identification of Contaminants of Ecological Concern ${ }^{\mathrm{a}}$

\begin{tabular}{|c|c|c|c|c|}
\hline Contaminant & $\begin{array}{c}\text { Maximum } \\
\text { Concentration }^{\mathrm{b}}\end{array}$ & $\begin{array}{c}\text { Background } \\
\text { Concentration }^{\mathrm{c}}\end{array}$ & $\begin{array}{c}\text { Screening } \\
\text { Concentration } \\
\end{array}$ & $\begin{array}{c}\text { Retain } \\
\text { as } \\
\text { COEC }\end{array}$ \\
\hline \multicolumn{5}{|l|}{ Metals $(\mu g / L)$} \\
\hline Aluminum & 7,000 & 200 & 87 & Yes \\
\hline Antimony & 33 & 33 & NA & No \\
\hline Arsenic & 8.7 & $<5.0$ & 190 & No \\
\hline Barium & 340 & 97 & 4.0 & Yes \\
\hline Calcium & 180,000 & 72,000 & 120,000 & Yes \\
\hline Cadmium & 1.5 & $<3.0$ & 2.4 & No \\
\hline Chromium & 57 & $<4.0$ & 11 & Yes \\
\hline Copper & 16 & 17 & 27 & No \\
\hline Iron & 7,810 & 1,100 & 1,000 & Yes \\
\hline Lead & 12 & $<2.0$ & 11 & Yes \\
\hline Magnesium & 18,000 & 16,000 & 82,000 & No \\
\hline Manganese & 1,300 & 370 & 120.0 & Yes \\
\hline Mercury & 0.10 & $<0.10$ & 1.3 & No \\
\hline Nickel & 16 & $<16$ & 350 & No \\
\hline Potassium & 6,100 & 3,100 & 53,000 & No \\
\hline Selenium & 5.5 & $<5.0$ & 5.0 & Yes \\
\hline Silver & 13 & ND & 21 & No \\
\hline Sodium & 17,000 & 6,600 & 680,000 & No \\
\hline Thallium & 6.4 & $<5.0$ & 12 & No \\
\hline Uranium, total & 6,000 & 4.3 & 2.6 & Yes \\
\hline Vanadium & 23 & 14 & 20 & Yes \\
\hline Zinc & 85 & 13 & 230 & No \\
\hline \multicolumn{5}{|c|}{ Inorganic anions $(m g / L)$} \\
\hline Chloride & 22 & 9.5 & NA & Yes \\
\hline Fluoride & 0.60 & 0.20 & 15 & No \\
\hline Nitrate & 9.9 & 0.70 & 90 & No \\
\hline Sulfate & 290 & 21 & NA & Yes \\
\hline \multicolumn{5}{|c|}{ Nitroaromatic compounds $(\mu g / L)$} \\
\hline $1,3,5-\mathrm{TNB}$ & 0.04 & NA & $1,000^{\mathrm{e}}$ & No \\
\hline $2,4,6-\mathrm{TNT}$ & 0.067 & NA & $2,800^{\mathrm{e}}$ & No \\
\hline $2,4-\mathrm{DNT}$ & 0.037 & NA & $230^{\mathrm{e}}$ & No \\
\hline 2,6-DNT & 0.026 & NA & $230^{\mathrm{e}}$ & No \\
\hline
\end{tabular}

a $\mathrm{NA}=$ not available; $\mathrm{ND}=$ not detected.

b Maximum concentration of site-related contaminants from data collected since 1987.

c Background concentrations are those reported for Femme Osage Creek (MK-Ferguson Company and Jacobs Engineering Group 1997).

d See Table 6.2 for source of screening values.

e From Talmadge and Opresko (1996). 
TABLE 2.3 Screening Evaluation of Sediment for the Identification of Contaminants of Ecological Concern ${ }^{\mathrm{a}}$

\begin{tabular}{|c|c|c|c|c|}
\hline Contaminant & $\begin{array}{c}\text { Maximum } \\
\begin{array}{c}\text { Concentration } \\
(\mathrm{mg} / \mathrm{kg})\end{array}\end{array}$ & $\begin{array}{c}\text { Background } \\
\text { Concentration }^{\mathrm{c}} \\
(\mathrm{mg} / \mathrm{kg})\end{array}$ & $\begin{array}{c}\begin{array}{c}\text { Screening } \\
\text { Concentration } \\
(\mathrm{mg} / \mathrm{kg})\end{array} \\
\end{array}$ & $\begin{array}{l}\text { Retain } \\
\text { as } \\
\text { COEC }\end{array}$ \\
\hline \multicolumn{5}{|l|}{ Metals } \\
\hline Aluminum & 20,000 & 13,000 & $\mathrm{NA}$ & Yes \\
\hline Antimony & 36 & $\mathrm{ND}$ & 2.0 & Yes \\
\hline Arsenic & 22 & 6.8 & 8.2 & Yes \\
\hline Barium & 350 & 150 & NA & Yes \\
\hline Cadmium & 4.2 & ND & 1.2 & Yes \\
\hline Calcium & 69,000 & 5,200 & $\mathrm{NA}$ & Yes \\
\hline Chromium & 50 & 16 & 81 & No \\
\hline Copper & 30 & 14 & 34 & No \\
\hline Iron & 28,000 & 17,000 & NA & Yes \\
\hline Lead & 48 & 15 & 47 & Yes \\
\hline Magnesium & 5,400 & 2,700 & NA & Yes \\
\hline Manganese & 1,100 & 810 & 460 & Yes \\
\hline Mercury & 0.99 & 0.10 & 0.15 & Yes \\
\hline Molybdenum & 3.9 & $\mathrm{ND}$ & NA & Yes \\
\hline Nickel & 28 & 21 & 21 & Yes \\
\hline Potassium & 3,400 & 1,400 & NA & Yes \\
\hline Selenium & 27 & 0.99 & NA & Yes \\
\hline Sodium & 250 & 130 & NA & Yes \\
\hline Thallium & 2.2 & 3.2 & NA & No \\
\hline Uranium, total & 14 & 5.5 & NA & Yes \\
\hline Vanadium & 44 & 31 & NA & Yes \\
\hline Zinc & 180 & 69 & 150 & Yes \\
\hline \multicolumn{5}{|l|}{ Inorganic anions } \\
\hline Chloride & 40 & 24 & $\mathrm{NA}$ & Yes \\
\hline Fluoride & 6.7 & 4.6 & NA & Yes \\
\hline Nitrate & 0.55 & 0.66 & NA & No \\
\hline Sulfate & 640 & 0.29 & $\mathrm{NA}$ & Yes \\
\hline \multicolumn{5}{|c|}{ Nitroaromatic compounds } \\
\hline $1,3,5-\mathrm{TNB}$ & 0.14 & $0^{\mathrm{e}}$ & 0.30 & No \\
\hline $1,3-\mathrm{DNB}$ & 0.01 & $0^{\mathrm{e}}$ & 1.20 & No \\
\hline 2,4,6-TNT & 0.01 & $0^{\mathrm{e}}$ & 13.0 & No \\
\hline 2,4-DNT & 0.01 & $0^{\mathrm{e}}$ & NA & Yes \\
\hline 2,6-DNT & 0.02 & $0^{\mathrm{e}}$ & $\mathrm{NA}$ & Yes \\
\hline Nitrobenzene & 0.01 & $0^{\mathrm{e}}$ & $\mathrm{NA}$ & Yes \\
\hline
\end{tabular}

a $\mathrm{NA}=$ not available $; \mathrm{ND}=$ not detected.

b Maximum concentration of site-related contaminants from data collected since 1987.

c Background concentrations are those reported for Femme Osage Creek (MK-Ferguson Company and Jacobs Engineering Group 1997).

d See Table 6.2 for source of screening values.

e Background concentrations of anthropogenic nitroaromatic compounds considered to be zero. 
TABLE 2.4 Final List of Contaminants of Ecological Concern for the $\mathrm{QROU}^{\mathrm{a}}$

\begin{tabular}{|c|c|c|}
\hline Contaminant & Surface Water & Sediment \\
\hline \multicolumn{3}{|l|}{ Metals } \\
\hline Aluminum & + & + \\
\hline Antimony & - & + \\
\hline Arsenic & - & + \\
\hline Barium & + & + \\
\hline Cadmium & - & + \\
\hline Calcium & + & + \\
\hline Chromium & + & - \\
\hline Iron & + & + \\
\hline Lead & + & + \\
\hline Magnesium & - & + \\
\hline Manganese & + & + \\
\hline Mercury & - & + \\
\hline Molybdenum & - & + \\
\hline Nickel & - & + \\
\hline Potassium & - & + \\
\hline Selenium & + & + \\
\hline Sodium & - & + \\
\hline Uranium, total & + & + \\
\hline Vanadium & + & + \\
\hline Zinc & - & + \\
\hline \multicolumn{3}{|l|}{ Inorganic anions } \\
\hline Chloride & + & + \\
\hline Fluoride & - & + \\
\hline Nitrate & - & - \\
\hline Sulfate & + & + \\
\hline \multicolumn{3}{|c|}{ Nitroaromatic compounds } \\
\hline $2,4 \mathrm{DNT}$ & - & $+1-$ \\
\hline 2,6-DNT & - & $+1-$ \\
\hline Nitrobenzene & - & $+1-$ \\
\hline
\end{tabular}

a The designation $+/$ - indicates that the contaminant has been retained as a COEC because no background or screening values are available; a minus $(-)$ sign indicates that the contaminant is not a COEC; and a plus $(+)$ sign indicates that the contaminant is a COEC. 


\section{EXPOSURE ASSESSMENT}

The Weldon Spring quarry is within the Weldon Spring Conservation Area - which, along with the August A. Busch Memorial Conservation Area to the north and the Howell Island Conservation Area to the east - is managed by the Missouri Department of Conservation for recreational use. Bulk waste disposed of at the quarry was removed during cleanup activities conducted under remediation of the Weldon Spring site quarry bulk waste operable unit. The quarry is fenced, and access by the general public is restricted. These controls will be kept in place by DOE until remedial activities have been completed and final quarry restoration and ownership have been determined.

Currently, Femme Osage Slough is accessible to the general public for fishing and other recreational activities. Future plans for this area include more intensive recreational use, with the possible development of wetlands. Contamination has been indicated in the alluvial groundwater of the quarry area north of Femme Osage Slough. Groundwater in the immediate area of the quarry north of the slough is not currently used for residential, agricultural, or other purposes. Contamination from the QROU has not affected the St. Charles County well field south of the slough.

\subsection{IDENTIFICATION OF EXPOSURE PATHWAYS}

Potential human and biotic exposure pathways were identified on the basis of the following factors:

- Locations of contaminated source areas, types of contaminants found at those areas, and potential mechanisms of contaminant release from those areas;

- Likely fate and transport of the contaminants within or between environmental media;

- Estimated concentrations of contaminants at points of potential human contact (i.e., exposure points) and the associated probable routes of human exposure;

- Completeness of each exposure pathway - that is, the presence of a contaminant source, a mechanism of contaminant release, and environmental transport medium; a point of human contact with the contaminated source or medium; and a route of human and/or biota exposure at that point. 
All of the above factors were considered in developing the conceptual site exposure model presented in Figure 3.1. Potential human receptors were identified for each area (i.e., quarry proper and Femme Osage Slough) under current and future land use. The human receptors and exposure pathways evaluated for each area are summarized in Table 3.1. ${ }^{1}$ The contaminant intake parameters and exposure factors used to calculate intakes are listed in Table 3.2.

\subsubsection{Quarry Proper}

Potential exposure of a member of the general public to current conditions at the quarry proper is unlikely because DOE actively monitors the quarry to restrict unauthorized access. Under future conditions, it is expected that land use in the area outside of the quarry proper would remain recreational, in which case the most likely future quarry receptor would be a recreational visitor. The most likely exposure routes for the recreational visitor would be external irradiation, incidental ingestion of and dermal contact with soil, and ingestion of surface water from the quarry pond. Although exposure to surface water is identified as a potential pathway, it is likely not a concern because restoration is expected to include engineering to prevent refilling of the quarry pond with water. Ingestion of surface water was retained as an exposure pathway because plans for restoration have not been finalized. The potential for inhalation of contaminated airborne particulates is expected to be very low because soil areas would be vegetated, and any remaining loose material would be in cracks and crevices on the quarry walls and floors. However, inhalation of air particulates was retained as a pathway for assessment.

In the unlikely event that a person would wander into the quarry under current conditions, the potential exposure routes would be similar to those for the future recreational visitor, but the overall risk would be much less because exposure frequency and duration would likely be less.

\subsubsection{Femme Osage Slough}

The most likely receptor at the Femme Osage Slough area under both current and future conditions is a recreational visitor. Potential risk under current and future land use would be similar because risk projections would be based on similar pathways of exposure and contaminant concentrations. The routes of exposure by which a recreational visitor at the slough could be exposed include ingestion of surface water and sediment and ingestion of fish. Dermal contact with surface water and sediment was also evaluated but is considered to be very unlikely because of the physical features of the slough. Similarly, inhalation of air particulates is considered to be unlikely because the presence of surface water in the slough would likely prevent the release of contaminant particles

1 All tables in this chapter have been placed at the end of the text (after Section 3.4.3). 


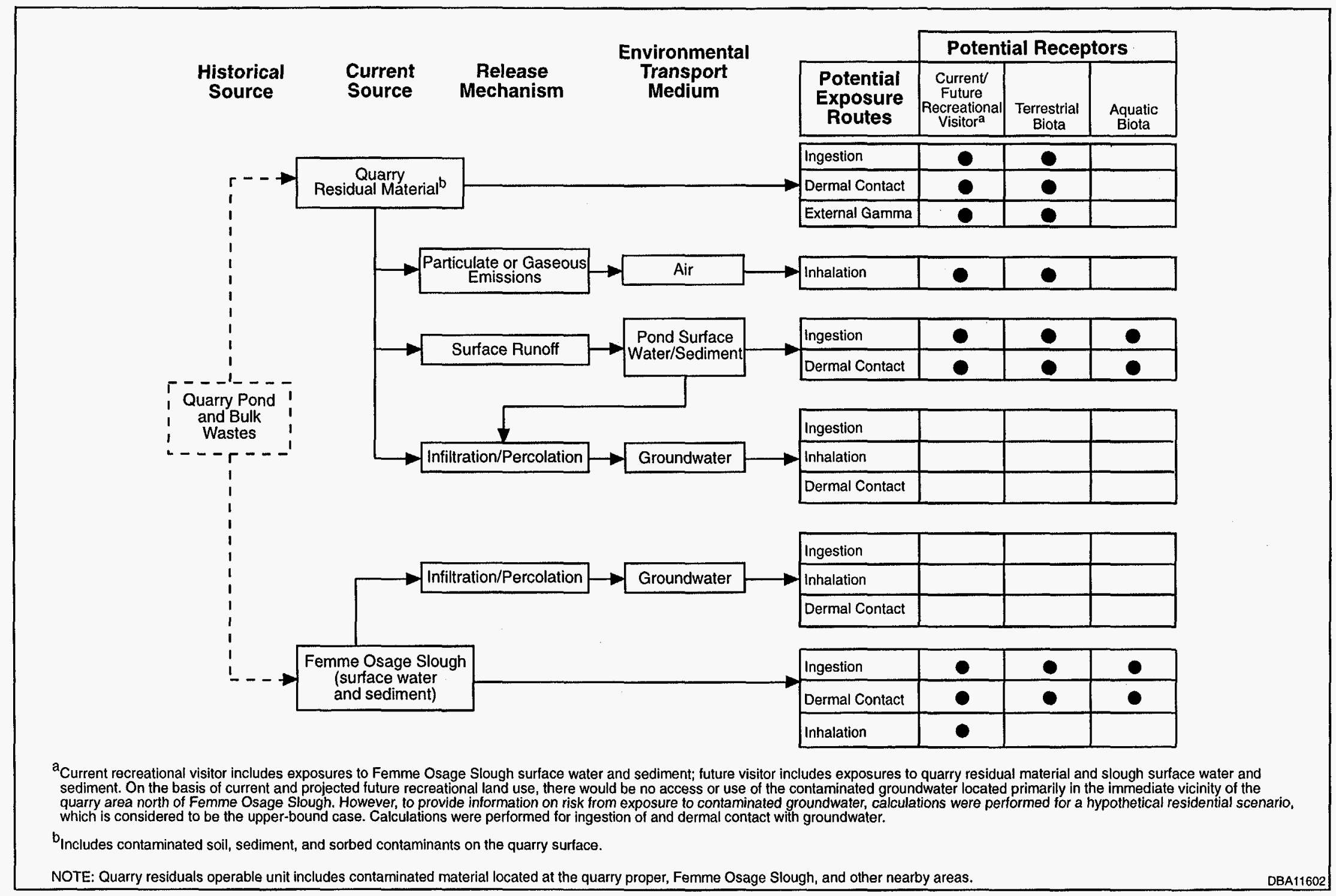

\section{FIGURE 3.1 Conceptual Site Exposure Model}


to the air; however, this pathway was evaluated in this analysis. External gamma irradiation is not a pathway of concern because concentrations of uranium are low, and the surface water attenuates any gamma radiation from the sediment.

\subsubsection{Groundwater at the Quarry}

Groundwater contamination occurs primarily in the immediate vicinity of the quarry area north of Femme Osage Slough. Because future land use is projected to be the same as current land use (recreational), no access or use of the contaminated groundwater would be expected. Even if land use were to change in the area, groundwater would be difficult to obtain from the shallow aquifer because of the aquifer's hydrogeologic properties (e.g., low transmissivities and low yields) (see Chapter 7 of the RI [MK-Ferguson Company and Jacobs Engineering Group 1997]). In addition, evaluation of fate and transport indicates that contamination in groundwater will not affect the St. Charles County well field (i.e., current constituent concentrations at the well field will not increase). The reasons for this conclusion include high sorption of uranium on the fine-grained alluvium north of the slough and high dilution in the thick layer of coarse-grained alluvium south of the slough. The data also indicate potential for the existence of a natural redox front that causes precipitation of uranium compounds.

Although contact with groundwater by a current or future receptor is an incomplete pathway, risk calculations were performed for a hypothetical residential scenario for informational purposes. For this scenario, the pathways evaluated included ingestion of groundwater and dermal contact while showering. Inhalation via release of contaminants to indoor air was not included because contaminants present in groundwater (primarily uranium and nitroaromatic compounds) do not appreciably volatilize from groundwater. Similar calculations for recreational use of the groundwater would result in hazard indices or risks of approximately one-hundredth of those estimated for the hypothetical future resident.

\subsection{ESTIMATION OF EXPOSURE POINT CONCENTRATIONS}

A medium-specific concentration of a contaminant at the location of exposure (i.e., exposure point concentration [EPC]) must be estimated to calculate the potential risk that might be associated with a contaminated source or medium. For these risk assessment calculations, contaminant-specific EPCs were developed for each contaminated medium associated with the quarry area. These media include soil in the quarry proper; sediment, surface water, and fish in Femme Osage Slough; surface water in the quarry pond; and groundwater.

The EPCs for soil in the quarry proper were determined for each COPC on the basis of data collected during the RI. The quarry proper was evaluated as two separate exposure units — soil areas 
and fractures. Data from soil areas were aggregated as one exposure unit to represent the likelihood that a visitor would not preferentially visit one area over another. Data from fractures were combined as a separate exposure unit because the probability of human contact is much less for soil in fractures than for soil areas. Exposures from ingestion, inhalation, and external gamma radiation were evaluated for both soil areas and fractures. Exposures from dermal contact were evaluated only for the soil areas because it is unlikely that a recreational visitor would be in direct contact with the soil in fractures. The EPCs used to calculate intakes for the quarry proper are shown in Tables 3.3 and 3.4. These concentrations were calculated by using the one-tailed $95 \%$ upper confidence limit of the arithmetic average (UCL) or the maximum concentration, whichever was lower (per EPA guidance; see EPA 1989a).

Femme Osage Slough was evaluated as one exposure unit to represent results for an individual who did not selectively visit one particular location at the slough. The EPCs for surface water and sediment, determined for each COPC on the basis of data presented in the RI (MK-Ferguson Company and Jacobs Engineering Group 1997), are presented in Table 3.5. For sediment, UCL concentrations were calculated for each COPC by using data presented in the RI. For surface water, bounding calculations were performed by using the maximum concentration detected for each contaminant. Determination of these maximum concentrations from more recent data was preferable because these data are considered to be more representative of current conditions in the area, reflecting bulk waste removal from the quarry. However, because of consistently low concentrations of chemicals in the slough, sampling for chemicals was discontinued after 1994. Therefore, the maximum concentration for each chemical contaminant was determined from available data through 1994. The maximum concentration of uranium was determined from data collected since 1995. For ingestion of fish caught from the slough, bounding calculations were performed by using the maximum concentration detected in the edible portion of fish for each contaminant; these EPCs used to calculate intakes from ingestion of fish are shown in Table 3.6. A separate evaluation for the Little Femme Osage Creek and Femme Osage Creek is not presented in this BRA. The EPCs are lower at the creeks than at the slough. Hence, the risk calculations performed for the slough should be adequately representative of the potential risk at these creeks as well.

Exposure point calculations for groundwater were determined for each COPC on the basis of data collected since 1995. UCL concentrations were calculated for each COPC and were used to calculate intakes from ingestion and dermal contact. The EPCs and intakes are shown in Table 3.7 for uranium, Table 3.8 for metals, and Tables 3.9 and 3.10 for nitroaromatic compounds.

\subsection{ESTIMATION OF CONTAMINANT INTAKE BY HUMANS}

Estimates of chemical and radioactive contaminant intake by humans are based on contaminant concentrations at the exposure points (Section 3.2) and scenario-specific exposure 
assumptions and intake parameters. The exposure assumptions and intake parameters used to calculate intakes are listed in Table 3.2; these values are consistent with recommendations by the EPA (1995b, 1992a). A recreational visitor was evaluated for the quarry proper and for Femme Osage Slough. It was assumed that the individual would visit the area for 4 hours, 20 times per year, over a period of 30 years. At the quarry proper, intakes were estimated for external irradiation, inhalation of contaminated particulates, and ingestion of and dermal contact with surface water and soil. For a recreational visitor at the slough, intakes were estimated for ingestion of and dermal contact with surface water, ingestion and inhalation of and dermal contact with sediment, and ingestion of fish.

The possibility that the recreational visitor could be a child who potentially could be more sensitive to contamination at the QROU was not evaluated separately. The intakes for the child would be less than those estimated for the recreational visitor because the exposure duration would be shorter. In addition, a soil/sediment ingestion rate of $120 \mathrm{mg} / \mathrm{event}$ was assumed for the recreational visitor to account for potentially higher ingestion rates of a child (i.e., from age 1 to 6 years). The EPA (1991) recommends ingestion rates of $100 \mathrm{mg} / \mathrm{event}$ for adults and $200 \mathrm{mg} / \mathrm{event}$ for children 1 to 6 years of age. Intakes calculated for the other pathways (i.e., inhalation, dermal, and ingestion of surface water and fish) were based on exposure of an adult and would bound exposures of a child because assumed rates for ingestion and inhalation and exposed skin surface area are greater for the adult receptor.

The methodologies used to calculate intakes from each route of exposure are presented in Section 3.3.1 for chemical contaminants and in Section 3.3.2 for radioactive contaminants. Dermal exposures to soil, sediment, and surface water were evaluated for this assessment but should be interpreted qualitatively because of limitations in the methodology for evaluating this pathway (EPA 1992a). For soil, EPA recommends quantifying dermal exposure for a contaminant only if there is some experimental basis for estimating the amount of the contaminant that is absorbed. For contaminants associated with the QROU, dermal absorption fractions are available only for PCBs (Schaum 1991). For the inorganic contaminants, a bounding upper-limit estimate was calculated using the gastrointestinal absorption fraction $\left(f_{1}\right)$ (DOE 1988); a value of 0.2 was assumed for nitroaromatic compounds. For dermal contact with surface water, dermal permeability coefficients were used in the intake equation to estimate the amount of contaminant that could be absorbed per unit area of skin per unit time. Contaminant-specific permeability coefficients were not available for the contaminants associated with the QROU; therefore, the default value of $1 \times 10^{-3}$ was used (Schaum 1991).

\subsubsection{Chemical Intakes}

Exposure to chemical contaminants is expressed in terms of intake. Intake is the amount of contaminant taken into the body per unit body weight per unit time (expressed as milligrams of contaminant per kilogram of body weight per day $[\mathrm{mg} / \mathrm{kg}-\mathrm{d}]$ ). Estimates of intakes were calculated 
for ingestion of water, sediment, and fish; dermal contact; and inhalation of contaminated particulates. The intake of chemical contaminant $\mathrm{i}\left(\mathrm{I}_{\mathrm{i}}\right)$ from ingestion of water was calculated as follows:

$$
\mathrm{I}_{\mathrm{i}}=\mathrm{C}_{\mathrm{wi}} \times \mathrm{R}_{\mathrm{w}} \times \mathrm{EF} \times \mathrm{ED} / \mathrm{BW} \times \mathrm{AT},
$$

where:

$$
\begin{aligned}
& C_{w i}=\text { concentration of contaminant } \mathrm{i} \text { in water }(\mathrm{mg} / \mathrm{L}), \\
& \mathbb{R}_{\mathrm{w}}=\text { water ingestion rate (L/event), } \\
& \mathrm{EF}=\text { exposure frequency (events/yr), } \\
& \mathrm{ED}=\text { exposure duration }(\mathrm{yr}), \\
& \mathrm{BW}=\text { average body weight over the exposure period }(\mathrm{kg}), \text { and } \\
& \text { AT }=\text { averaging time }(\mathrm{d}) .
\end{aligned}
$$

The chemical EPCs and estimated intakes for a recreational visitor from ingestion of surface water at the slough and creeks are presented in Tables 3.5 and 3.6, respectively. The EPCs and estimated intakes for a hypothetical resident from ingestion of groundwater are shown in Table 3.8 for metals and in Tables 3.9 and 3.10 for nitroaromatic compounds.

The intake of chemical contaminant $i\left(\mathrm{I}_{\mathbf{i}}\right)$ from ingestion of soil or sediment was calculated as follows:

$$
\mathrm{I}_{\mathrm{i}}=\mathrm{C}_{\mathrm{si}} \times \mathrm{IR}_{\mathrm{s}} \times \mathrm{CF}_{1} \times \mathrm{EF} \times \mathrm{ED} / \mathrm{BW} \times \mathrm{AT},
$$

where:

$$
\begin{aligned}
& \mathrm{C}_{\mathrm{si}}=\text { concentration of contaminant } \mathrm{i} \text { in soil or sediment }(\mathrm{mg} / \mathrm{kg}), \\
& \mathbb{R}_{\mathrm{s}}=\text { soil (or sediment) ingestion rate }(\mathrm{mg} / \text { event), and } \\
& \mathrm{CF}_{1}=\text { conversion factor }\left(1 \times 10^{-6} \mathrm{~kg} / \mathrm{mg}\right)
\end{aligned}
$$

Tables 3.3 and 3.5 present the chemical EPCs and estimated intakes from ingestion of soil or sediment for a recreational visitor at the quarry proper and slough, respectively. 
Intake of chemical contaminant $\mathbf{i}\left(\mathrm{I}_{\mathbf{i}}\right)$ from ingestion of fish from the slough was calculated as follows:

$$
\mathrm{I}_{\mathrm{i}}=\mathrm{C}_{\mathrm{fi}} \times \mathrm{IR}_{\mathrm{f}} \times \mathrm{CF}_{2} \times \mathrm{EF} \times \mathrm{ED} / \mathrm{BW} \times \mathrm{AT}
$$

where:

$$
\begin{aligned}
& \mathrm{C}_{\mathrm{fi}}=\text { concentration of chemical contaminant } \mathrm{i} \text { in fish tissue }(\mathrm{mg} / \mathrm{kg}), \\
& \mathrm{CF}_{2}=\text { conversion factor }\left(1 \times 10^{-3} \mathrm{~kg} / \mathrm{g}\right) \text {, and } \\
& \mathrm{IR}_{\mathrm{f}}=\text { ingestion rate of fish }(\mathrm{g} / \text { event }) \text {. }
\end{aligned}
$$

Table 3.6 presents the EPCs and estimated intakes for the recreational visitor from ingestion of fish.

The intake of chemical contaminant $i\left(\mathrm{I}_{\mathrm{i}}\right)$ from inhalation of soil was calculated as follows:

$$
\mathrm{I}_{\mathrm{i}}=\mathrm{C}_{\mathrm{ai}} \times \mathrm{IR}_{\mathrm{a}} \times \mathrm{ET} \times \mathrm{EF} \times \mathrm{ED} / \mathrm{BW} \times \mathrm{AT}
$$

where:

$$
\begin{aligned}
& C_{a i}=\text { concentration of contaminant } \mathrm{i} \text { as respirable particulates }\left(\mathrm{mg} / \mathrm{m}^{3}\right) \text {, } \\
& \mathrm{IR}_{\mathrm{a}}=\text { inhalation rate }\left(\mathrm{m}^{3} / \mathrm{h}\right), \text { and } \\
& \mathrm{ET}=\text { exposure time }(\mathrm{h})
\end{aligned}
$$

The chemical EPCs and estimated intakes from inhalation of air particulates are presented in Table 3.3.

The intake of chemical contaminant $\mathrm{i}\left(\mathrm{I}_{\mathrm{i}}\right)$ from dermal contact with contaminated soil and sediment was calculated as follows:

$$
\mathrm{I}_{\mathrm{i}}=\frac{\mathrm{C}_{\mathrm{si}} \times \mathrm{SA} \times \mathrm{AF} \times \mathrm{ABS}_{\mathrm{i}} \times \mathrm{CF}_{1} \times \mathrm{EF} \times \mathrm{ED}}{\mathrm{BW} \times \mathrm{AT}},
$$

where:

$\mathrm{SA}=$ skin surface area $\left(\mathrm{cm}^{2} /\right.$ event $)$, and

$\mathrm{AF}=$ soil-to-skin adherence factor $\left(\mathrm{mg} / \mathrm{cm}^{2}\right)$, and

$\mathrm{ABS}_{\mathrm{i}}=$ fraction of contaminant $\mathrm{i}$ absorbed (unitless) 
Tables 3.3 and 3.5 present the estimated intakes from dermal contact for a recreational visitor at the quarry proper and slough, respectively.

The intake of chemical contaminant $\mathrm{i}\left(\mathrm{I}_{\mathrm{i}}\right)$ from dermal contact with contaminated surface water was calculated as follows:

$$
\mathrm{I}_{\mathrm{i}}=\frac{\mathrm{C}_{\mathrm{Wi}} \times \mathrm{SA} \times \mathrm{PC}_{\mathrm{i}} \times \mathrm{CF}_{3} \times \mathrm{ET} \times \mathrm{EF} \times \mathrm{ED}}{\mathrm{BW} \times \mathrm{AT}},
$$

where:

$$
\begin{aligned}
& \mathrm{PC}_{\mathrm{i}}=\text { dermal permeability coefficient for contaminant } \mathrm{i}(\mathrm{cm} / \mathrm{h}) \text { and } \\
& \mathrm{CF}_{3}=\text { conversion factor }\left(10^{-3} \mathrm{~L} / \mathrm{cm}^{3}\right) \text {. }
\end{aligned}
$$

The estimated intakes from dermal contact with surface water are presented in Table 3.5.

\subsubsection{Radiological Intakes}

Intake values for radioactive contaminants were calculated by methods similar to those used to calculate intake of chemical carcinogens. Radiological intake is the amount of contaminant taken into the body, expressed in $\mathrm{pCi}$. Estimates of intakes were calculated for ingestion of water, soil, and fish; dermal contact; and external irradiation. The intake of radioactive contaminant $i\left(I_{i}\right)$ from ingestion of water was calculated as follows:

$$
\mathrm{I}_{\mathrm{i}}=\mathrm{R}_{\mathrm{wi}} \times \mathrm{IR}_{\mathrm{w}} \times \mathrm{EF} \times \mathrm{ED},
$$

where:

$$
R_{\mathrm{wi}}=\text { concentration of radionuclide } \mathrm{i} \text { in water }(\mathrm{pCi} / \mathrm{L}) \text {. }
$$

The radiological EPCs and estimated intakes for ingestion of surface water for a recreational visitor at the slough and creeks are presented in Tables 3.5 and 3.6, respectively. The EPCs and estimated intakes of uranium for a hypothetical resident are presented in Table 3.7.

Intakes of radioactive contaminant $i\left(\mathrm{I}_{\mathrm{i}}\right)$ from ingestion of soil or sediment were calculated as follows:

$$
\mathrm{I}_{\mathrm{i}}=\mathrm{R}_{\mathrm{si}} \times \mathrm{IR}_{\mathrm{s}} \times \mathrm{CF}_{4} \times \mathrm{EF} \times \mathrm{ED},
$$


where:

$$
\begin{aligned}
& \mathrm{R}_{\mathrm{si}}=\text { concentration of radionuclide } \mathrm{i} \text { in soil or sediment }(\mathrm{pCi} / \mathrm{g}) \text { and } \\
& \mathrm{CF}_{4}=\text { conversion factor }\left(1 \times 10^{-3} \mathrm{~g} / \mathrm{mg}\right)
\end{aligned}
$$

The EPCs and estimated intakes for ingestion of soil or sediment by a recreational visitor at the quarry proper and slough are presented in Tables 3.4 and 3.5, respectively.

Intake of radioactive contaminant $i\left(\mathrm{I}_{\mathrm{i}}\right)$ from ingestion of fish from the slough was calculated as follows:

$$
\mathrm{I}_{\mathrm{i}}=\mathrm{R}_{\mathrm{fi}} \times \mathrm{IR}_{\mathrm{f}} \times \mathrm{EF} \times \mathrm{ED}
$$

where:

$\mathrm{R}_{\mathrm{fi}}=$ concentration of radionuclide $\mathrm{i}$ in fish tissue $(\mathrm{pCi} / \mathrm{g})$.

The estimated intakes from ingestion of fish from the slough are presented in Table 3.6.

The intake of radioactive contaminant $i\left(\mathrm{~L}_{\mathrm{i}}\right)$ from inhalation of soil was calculated as follows:

$$
\mathrm{I}_{\mathrm{i}}=\mathrm{R}_{\mathrm{ai}} \times \mathrm{IR}_{\mathrm{a}} \times \mathrm{ET} \times \mathrm{EF} \times \mathrm{ED},
$$

where:

$\mathrm{R}_{\mathrm{ai}}=$ concentration of contaminant $\mathrm{i}$ as respirable particulates $\left(\mathrm{pCi} / \mathrm{m}^{3}\right)$.

The EPCs and estimated intakes from inhalation of contaminated particulates by a recreational visitor in the quarry proper are presented in Table 3.4 .

The intake of radioactive contaminant $i\left(\mathrm{I}_{\mathrm{i}}\right)$ from external irradiation (in units of $\mathrm{pCi}-\mathrm{yr} / \mathrm{g}$ ) was calculated as follows:

$$
\mathrm{I}_{\mathrm{i}}=\mathrm{R}_{\mathrm{si}} \times \mathrm{ET} \times \mathrm{EF} \times \mathrm{ED} \times 1 / 8760 \mathrm{~h}
$$

Table 3.4 presents the estimated intakes from external irradiation to a recreational visitor at the quarry proper. The estimated radiological dose from external radiation was also calculated using the average of the exposure rate measurements reported for the quarry proper. The radiological dose (in units of mrem) from external gamma irradiation was calculated by multiplying the length of time an 
individual was assumed to be exposed to the radiation field strength and the dose conversion factor of $0.95 \mathrm{mrem} / \mathrm{mR}$.

The intake of radioactive contaminant $\mathrm{i}\left(\mathrm{I}_{\mathrm{i}}\right)$ from dermal contact with soil or sediment was calculated as follows:

$$
I_{i}=R_{S i} \times S A \times A F \times A B S_{i} \times \mathrm{CF}_{4} \times E F \times E D
$$

The estimated intakes from dermal absorption are presented in Table 3.4 for the quarry proper and in Table 3.5 for the slough.

The intake of radioactive contaminant $i\left(\mathrm{I}_{\mathrm{i}}\right)$ from dermal contact with surface water was calculated as follows:

$$
\mathrm{I}_{\mathrm{i}}=\mathrm{R}_{\mathrm{Wi}} \times \mathrm{SA} \times \mathrm{PC}_{\mathrm{i}} \times \mathrm{CF}_{3} \times \mathrm{ET} \times \mathrm{EF} \times \mathrm{ED}
$$

The estimated intake for dermal absorption of uranium by a recreational visitor at the slough is presented in Table 3.5 .

\subsection{ESTIMATION OF CONTAMINANT INTAKE BY BIOTA}

\subsubsection{Ecological Receptors}

Contaminant uptake was modeled for the mallard duck, great blue heron, bald eagle, and white-tailed deer. Because of the nature (small size, intermittent flow, steep topography, and extensive canopy) of Little Femme Osage Creek, use of this stream was not considered to be significant for these receptors, except for the white-tailed deer. The creek is too small to serve as foraging habitat for the bald eagle. Although the mallard and great blue heron may forage in the creek, these species are more likely to use the larger nearby waters, including the slough. In contrast, the white-tailed deer is more likely to drink from the creek; this drainage basin represents suitable habitat for this species. Thus, the uptake modeling considered exposure at only Femme Osage Slough for the mallard, great blue heron, and bald eagle, and exposure at both the slough and Little Femme Osage Creek for the white-tailed deer. 


\subsubsection{Equations for Estimating Intake}

\subsubsection{Chemical Uptake from Ingestion of Drinking Water}

To estimate chemical contaminant uptake for ecological receptors using Femme Osage Slough and Little Femme Osage Creek as drinking water sources, the following equation was used:

where:

$$
\mathrm{ADD}_{\mathrm{w}}=\sum_{\mathrm{i}=1}^{\mathrm{n}}\left(\mathrm{C}_{\mathrm{i}} \times \mathrm{FR}_{\mathrm{i}}\right) \times \mathrm{IR} / \mathrm{BW},
$$

$$
\begin{aligned}
& \mathrm{ADD}_{\mathrm{w}}=\text { applied daily dose (ADD) from drinking water }(\mathrm{mg} / \mathrm{kg}-\mathrm{d}) \text { summed } \\
& \text { over all drinking water sources, } \\
& \mathrm{C}_{\mathrm{i}}=\text { contaminant concentration in drinking water source } \mathrm{i}(\mathrm{mg} / \mathrm{L}) \text {, } \\
& \mathrm{FR}_{\mathrm{i}}=\text { fraction of total water ingestion from contaminated source } \mathrm{i} \text {, calculated } \\
& \text { as area of contaminated surface water body to total area of all surface } \\
& \text { water within the home range of the receptor species (\%, unitless), } \\
& \text { IR = ingestion rate of free water }(\mathrm{L} / \mathrm{d}) \text {, and } \\
& \mathrm{BW} \text { = body weight }(\mathrm{kg}) \text {. }
\end{aligned}
$$

\subsubsection{Chemical Uptake from Incidental Ingestion of Sediment}

Contaminant uptake from incidental ingestion of sediment from Femme Osage Slough was estimated using the following equation:

$$
\mathrm{ADD}_{\text {sed }}=(\mathrm{C} \times \mathrm{FS} \times \mathrm{IR} \times \mathrm{FR}) / \mathrm{BW} \text {, }
$$

where:

$$
\begin{aligned}
\mathrm{ADD}_{\text {sed }}= & \begin{array}{l}
\text { applied daily dose from the incidental ingestion of sediment } \\
(\mathrm{mg} / \mathrm{kg}-\mathrm{d})
\end{array} \\
\mathrm{C}= & \text { contaminant concentration in sediment }(\mathrm{mg} / \mathrm{kg}), \\
\mathrm{FS}= & \text { fraction of sediment in } \operatorname{diet}(\%, \text { unitless }),
\end{aligned}
$$




$$
\begin{aligned}
\mathrm{IR}= & \text { food ingestion rate }(\mathrm{kg} / \mathrm{d}), \\
\mathrm{FR} \mathrm{=} & \text { fraction of total food intake from contaminated area }(\%, \text { unitless), } \\
& \text { calculated in same manner as for water (see Section } 3.4 .2 .1), \text { and } \\
\mathrm{BW}= & \text { body weight }(\mathrm{kg}) .
\end{aligned}
$$

\subsubsection{Chemical Uptake from Ingestion of Food}

Contaminant uptake through food ingestion was estimated with the following equation:

$$
\mathrm{ADD}_{\mathrm{f}}=\sum_{\mathrm{i}=1}^{\mathrm{k}} \mathrm{C}_{\mathrm{k}} \times \mathrm{DF}_{\mathrm{k}} \times \mathrm{SU} \times \mathrm{NIR}
$$

where:

$$
\begin{aligned}
\mathrm{ADD}_{\mathrm{f}}= & \text { applied daily dose from food ingestion }(\mathrm{mg} / \mathrm{kg}-\mathrm{d}), \text { summed over } \\
& \text { all food items; } \\
\mathrm{C}_{\mathrm{k}}= & \text { average contaminant concentration in the food item } \mathrm{k}(\mathrm{mg} / \mathrm{kg}) ; \\
\mathrm{DF}_{\mathrm{k}}= & \text { fraction of total diet represented by food item } \mathrm{k}(\% \text {, unitless); } \\
\mathrm{SU}= & \text { site use factor, which represents the proportion of time the } \\
& \text { receptor occurs in the QROU area (the factor is used to estimate } \\
& \text { the proportion of daily intake originating from the QROU con- } \\
& \text { taminated area): } \\
= & \text { (area of contamination) } \div(\text { home range area); and } \\
= & \text { normalized ingestion rate of food }(\mathrm{kg} / \mathrm{kg}-\mathrm{d}) \\
= & {[\text { non-normalized ingestion rate }(\mathrm{IR})(\mathrm{kg} / \mathrm{d})] } \\
& \div[\text { body weight }(\mathrm{BW})(\mathrm{kg})] .
\end{aligned}
$$

\subsubsection{Radiological Intake}

The potential radiological doses to aquatic biota and terrestrial wildlife from exposure to uranium in surface water and sediment in Femme Osage Slough were examined for comparison with 
applicable dose limits specified in DOE Order 5400.5 (DOE 1990). The dose limit from exposure to radiation or radioactive material discharged in liquid waste to natural waterways for protection of aquatic biota is $1 \mathrm{rad} / \mathrm{d} ; 0.1 \mathrm{rad} / \mathrm{d}$ has been proposed for terrestrial animals.

The daily dose rate to terrestrial wildlife was estimated with the following equation by calculating the rate of energy deposition from uranium in tissue per unit body weight of the receptor:

Dose Rate $=\mathrm{TC} \times \mathrm{E} \times \mathrm{K}$,

where:

$$
\begin{aligned}
\mathrm{TC}= & \text { tissue concentration of the uranium }(\mathrm{pCi} / \mathrm{kg}), \\
\mathrm{E}= & \text { energy per decay }=10 \mathrm{MeV} / \text { decay for uranium (Publication } 38 \text { of the } \\
& \text { International Commission on Radiological Protection }[\text { ICRP 1983]), and } \\
\mathrm{K}= & \text { conversion constant } \\
= & 0.037(\text { decay } / \mathrm{s}-\mathrm{pCi}) \times 10^{-3}(\mathrm{~kg} / \mathrm{g}) \times 86400(\mathrm{~s} / \mathrm{d}) \\
& \times 1.6 \times 10^{-6}(\mathrm{erg} / \mathrm{MeV}) \times 0.01(\mathrm{rad}-\mathrm{g} / \mathrm{erg}) \\
= & 5.121 \times 10^{-8}(\mathrm{rad}-\mathrm{kg}) /(\mathrm{d}-\mathrm{MeV}-\mathrm{pCi}) .
\end{aligned}
$$

The tissue concentration (TC) was calculated with the following expression:

$$
\mathrm{TC}=\mathrm{C} \times \mathrm{f} \times \mathrm{ET} \times \mathrm{IR} / \mathrm{BW},
$$

where:

$\mathrm{C}=$ uranium concentration in food $(\mathrm{pCi} / \mathrm{g})$, surface water $(\mathrm{pCi} / \mathrm{L})$, or sediment (pCi/g),

$\mathrm{f}=$ absorption fraction (unitless),

ET = exposure time (d), calculated as the receptor's life expectancy multiplied by the site use factor,

$\mathbb{R}=$ ingestion rate of food $(\mathrm{g} / \mathrm{d})$, water $(\mathrm{L} / \mathrm{d})$, or sediment $(\mathrm{g} / \mathrm{d})$, and

BW $=$ body weight of the receptor $(\mathrm{kg})$. 
The above methodology was also used to estimate the dose rate to fish from ingestion of sediment. The dose rate to fish from exposure to surface water in the slough was determined with the following equation:

$$
\text { Dose Rate }=\mathrm{C} \times \mathrm{BF} \times \mathrm{E} \times \mathrm{K} \text {, }
$$

where:

$$
\begin{aligned}
\mathrm{C} & =\text { uranium concentration in surface water }(\mathrm{pCi} / \mathrm{L}) \\
\mathrm{BF} & =\text { bioaccumulation factor }(10 \mathrm{~L} / \mathrm{kg} \text { for uranium [Yu et al. 1993]), } \\
\mathrm{E} & =\text { energy per decay }=10 \mathrm{MeV} / \text { decay for uranium (ICRP 1983), and } \\
\mathrm{K} & =\text { conversion constant (see above). }
\end{aligned}
$$

\subsubsection{Exposure Factors}

Species-specific information on ingestion rate, body weight, life expectancy, diet composition, and home range was obtained from the EPA Wildlife Exposure Factors Handbook (EPA 1993), available scientific literature, and site-specific data (such as Bethel et al. 1993). Species-specific values for ingestion rates were directly available only for the white-tailed deer (Schwartz and Schwartz 1981). The following allometric equation (EPA 1993) was used to estimate the food ingestion rates for the mallard duck, great blue heron, and bald eagle:

$$
\mathrm{IR}=0.0582(\mathrm{BW})^{0.651}
$$

where:

$$
\begin{aligned}
\mathrm{IR} & =\text { ingestion rate }(\mathrm{kg} / \mathrm{d}), \text { and } \\
\mathrm{BW} & =\text { weight of the receptor }(\mathrm{kg})
\end{aligned}
$$

Exposure factors used for this risk assessment are presented in Table 3.11. 


\subsubsection{Model Assumptions}

Because only limited species-specific data were available, the following conservative assumptions were made in modeling contaminant uptake:

- The ingestion rate of each receptor would be constant over that receptor's entire home range.

- Biouptake would not significantly affect the environmental concentration of the contaminant.

- Assimilation of contaminants would be complete within each trophic level ( $100 \%$ of ingested contaminant assimilated); excretion of contaminants was ignored.

- Plant tissue contaminant concentrations would be equal to the contaminant concentrations in sediment.

- For estimation of radiological uptake, the absorbed fraction was assumed to be 0.1 .

- For terrestrial wildlife, the exposure time was estimated as the receptor's life expectancy multiplied by the ratio of the area of the slough to the home range.

- For estimation of the radiological dose, contaminants were assumed to be distributed homogeneously within the tissues of the receptor, and all energy liberated by each decay within the receptor was assumed to be totally absorbed.

\subsubsection{Estimation of Contaminant Doses}

Chemical contaminant uptake through ingestion of water, food, and sediment was estimated as an applied daily dose (ADD) for the mallard (Table 3.12) and the great blue heron (Table 3.13). Chemical contaminant doses from ingestion of water and food were estimated for the bald eagle (Table 3.14). The estimated chemical contaminant doses for the white-tailed deer from the ingestion of water from the slough and Little Femme Osage Creek are presented in Table 3.15.

Radiological daily dose estimates for the mallard, great blue heron, bald eagle, and white-tailed deer from ingestion of food, surface water, and/or sediment from the slough are presented in Table 3.16. The daily dose rate for fish inhabiting the slough was estimated to be $2.0 \times 10^{-2} \mathrm{rad} / \mathrm{d}$. 
TABLE 3.1 Human Receptors and Exposure Pathways for the QROU ${ }^{\mathrm{a}}$

\begin{tabular}{|c|c|c|c|c|c|}
\hline \multirow[b]{2}{*}{ Location/Receptor } & \multirow{2}{*}{$\begin{array}{c}\text { External } \\
\text { Gamma } \\
\text { Radiation } \\
\end{array}$} & \multicolumn{4}{|c|}{ Ingestion } \\
\hline & & $\begin{array}{c}\text { Surface } \\
\text { Water }\end{array}$ & $\begin{array}{c}\text { Sediment/ } \\
\text { Soil }\end{array}$ & Fish & Groundwater $^{\mathrm{b}}$ \\
\hline \multicolumn{6}{|l|}{ Quarry proper } \\
\hline Future recreational visitor & $\mathrm{X}$ & $\mathrm{X}$ & $\mathrm{X}$ & NA & IP \\
\hline \multicolumn{6}{|l|}{ Femme Osage Slough } \\
\hline Current recreational visitor & NA & $\mathrm{X}$ & $\mathrm{X}$ & $\mathrm{X}$ & IP \\
\hline Future recreational visitor & NA & $\mathrm{X}$ & $\mathrm{X}$ & $\mathrm{X}$ & IP \\
\hline & & \multicolumn{2}{|c|}{ Dermal } & & Inhalation \\
\hline Location/Receptor & & $\begin{array}{c}\text { Surface } \\
\text { Water }\end{array}$ & $\begin{array}{c}\text { Sediment/ } \\
\text { Soil }\end{array}$ & & $\begin{array}{c}\text { Sediment/ } \\
\text { Soil }\end{array}$ \\
\hline \multicolumn{6}{|l|}{ Quarry proper } \\
\hline Future recreational visitor & & $\mathrm{X}$ & $\mathrm{x}$ & & $\mathrm{X}$ \\
\hline \multicolumn{6}{|l|}{ Femme Osage Slough } \\
\hline Current recreational visitor & & $\mathrm{X}$ & $\mathrm{x}$ & & $\mathrm{X}$ \\
\hline Future recreational visitor & & $\mathrm{X}$ & $\mathrm{x}$ & & $\mathrm{X}$ \\
\hline
\end{tabular}

a An $\mathrm{X}$ indicates that the exposure pathway was assessed for this receptor; $\mathrm{NA}=$ not applicable; $\mathrm{IP}=$ incomplete pathway.

b On the basis of current and projected future land use, exposure to contaminated groundwater is an incomplete pathway. However, to provide information on potential risk, exposure to contaminated groundwater via ingestion and dermal contact was evaluated for a hypothetical future resident. 
TABLE 3.2 Exposure Scenario Assumptions and Intake Parameters for the Current and Future Recreational Visitor

\begin{tabular}{lcc}
\hline & & \\
& & $\begin{array}{c}\text { Value for } \\
\text { Recreational } \\
\text { Visitor }\end{array}$ \\
\hline & Unit & \\
Exposure time & & \\
Exposure frequency & h/event & $4(1)^{\mathrm{b}}$ \\
Exposure duration & events/yr & 20 \\
Body weight & $\mathrm{yr}$ & 30 \\
Sediment/soil ingestion rate & $\mathrm{kg}$ & 70 \\
Surface water ingestion rate & $\mathrm{mg} / \mathrm{event}$ & $120^{\mathrm{c}}$ \\
Inhalation rate & $\mathrm{mL} / \mathrm{event}$ & 200 \\
Particulate emission factor & $\mathrm{m}^{3} / \mathrm{h}$ & 2.1 \\
Fish ingestion rate & $\mathrm{m}^{3} / \mathrm{kg}$ & $4.63 \times 10^{9}$ \\
Surface area (arms, hands, lower legs) & $\mathrm{g} / \mathrm{event}$ & 55 \\
Surface area (hands) & $\mathrm{cm}^{2}$ & $4,200^{\mathrm{d}}$ \\
Adherence factor of soil to skin & $\mathrm{cm}^{2}$ & $820^{\mathrm{e}}$ \\
Permeability coefficient & $\mathrm{mg} / \mathrm{cm}^{2}$-event & $2 \times 10^{-1}$ \\
Absorption fraction & $\mathrm{cm}^{2} / \mathrm{h}$ & $1 \times 10^{-3}$ \\
Aluminum & $\mathrm{unitless}$ & \\
Antimony & & 0.01 \\
Arsenic & & 0.01 \\
Barium & & 0.5 \\
Beryllium & & 0.1 \\
Cadmium & & 0.005 \\
Copper & & 0.05 \\
Chromium & & 0.5 \\
Manganese & & 0.1 \\
Molybdenum & & 0.1 \\
Nickel & & 0.05 \\
Radium & & 0.05 \\
Selenium & & 0.2 \\
Silver & & 0.05 \\
Thallium & & 0.05 \\
Thorium & & 1.0 \\
Uranium & & 0.0002 \\
Vanadium & & 0.002 \\
Zinc & & 0.01 \\
PCBs & & 0.5 \\
Nitroaromatic compounds & & 0.1 \\
\hline & & 0.2 \\
\hline
\end{tabular}

a For the hypothetical residential calculations, a groundwater ingestion rate of $2 \mathrm{~L} / \mathrm{d}$ for 30 years was assumed for the ingestion pathway, and a surface area of $20,000 \mathrm{~cm}^{2}$ was assumed for dermal absorption from showering $10 \mathrm{~min} / \mathrm{d}$ over 30 years.

b Assumed to be wading for 1 hour in the slough.

c Includes 6 years for an ingestion rate of $200 \mathrm{mg}$ for a child, and 24 years for ingestion rate of $100 \mathrm{mg}$ per event for an adult.

d Assumed surface area for wading in the slough.

e Assumed surface area for contact with soil. 
TABLE 3.3 Exposure Point Concentrations and Estimated Chemical Contaminant Intakes for a Recreational Visitor at the Quarry Proper ${ }^{\text {a }}$

\begin{tabular}{|c|c|c|c|c|c|c|c|c|c|c|c|}
\hline \multirow[b]{4}{*}{ Contaminant } & \multicolumn{6}{|c|}{ Soil } & \multicolumn{5}{|c|}{ Fractures } \\
\hline & \multicolumn{3}{|c|}{ Concentration ( $\mathrm{mg} / \mathrm{kg}$ ) } & \multirow{2}{*}{\multicolumn{3}{|c|}{ Intake (mg/kg-d) }} & \multicolumn{3}{|c|}{ Concentration $(\mathrm{mg} / \mathrm{kg})$} & & \\
\hline & \multirow[b]{2}{*}{ Mean } & \multirow[b]{2}{*}{$\begin{array}{l}\text { Standard } \\
\text { Deviation }\end{array}$} & \multirow[b]{2}{*}{$\mathrm{EPC}^{\mathrm{b}}$} & & & & \multirow[b]{2}{*}{ Mean } & \multirow[b]{2}{*}{$\begin{array}{l}\text { Standard } \\
\text { Deviation }\end{array}$} & \multirow[b]{2}{*}{$\mathrm{EPC}^{\mathbf{b}}$} & \multicolumn{2}{|c|}{ Intake $(\mathrm{mg} / \mathrm{kg} \cdot \mathrm{d})$} \\
\hline & & & & Ingestion & Dermal & Inhalation & & & & Ingestion & Inhalation \\
\hline \multicolumn{12}{|l|}{ Metals } \\
\hline Aluminum & 9,700 & 3,600 & 11,000 & $9.9 \times 10^{-4}$ & $1.4 \times 10^{-5}$ & $1.5 \times 10^{-11}$ & 17,000 & 9,300 & 24,000 & $2.3 \times 10^{-3}$ & $3.5 \times 10^{-11}$ \\
\hline Selenium & 2.4 & 4.3 & 3.5 & $3.3 \times 10^{-7}$ & $2.3 \times 10^{-8}$ & $5.0 \times 10^{-15}$ & 10 & 14 & 22 & $2.0 \times 10^{-6}$ & $3.1 \times 10^{-14}$ \\
\hline Silver & 0.98 & 2.4 & 1.6 & $1.5 \times 10^{-7}$ & $1.0 \times 10^{-8}$ & $2.2 \times 10^{-15}$ & 4.0 & 5.6 & 8.7 & $8.2 \times 10^{-7}$ & $1.2 \times 10^{-14}$ \\
\hline Uranium & 14 & 22 & 17 & $1.6 \times 10^{-6}$ & $4.4 \times 10^{-4}$ & $2.4 \times 10^{-14}$ & 51 & 87 & 72 & $6.6 \times 10^{-6}$ & $1.0 \times 10^{-13}$ \\
\hline Zinc & 91 & 140 & 130 & $1.2 \times 10^{-5}$ & $8.3 \times 10^{-6}$ & $1.8 \times 10^{-13}$ & 91 & 24 & 110 & $1.0 \times 10^{-5}$ & $1.6 \times 10^{-13}$ \\
\hline \multicolumn{12}{|c|}{ Organic compounds } \\
\hline $1,3,5-\mathrm{TNB}$ & 0.20 & 0.60 & 0.35 & $3.3 \times 10^{-8}$ & $9.0 \times 10^{-9}$ & $5.0 \times 10^{-13}$ & 0.26 & 0.36 & 1.3 & $1.2 \times 10^{-7}$ & $1.8 \times 10^{-12}$ \\
\hline 1,3-DNB & 0.042 & 0.052 & 0.0020 & $2.2 \times 10^{-10}$ & $5.1 \times 10^{-11}$ & $3.4 \times 10^{-15}$ & $-c$ & - & - & - & - \\
\hline $2,4,6-\mathrm{TNT}$ & 0.13 & 0.48 & 0.24 & $\begin{array}{c}2.3 \times 10^{-8} \\
\left(9.8 \times 10^{-9}\right)\end{array}$ & $\begin{array}{c}6.2 \times 10^{-9} \\
\left(2.6 \times 10^{-4}\right)\end{array}$ & $3.4 \times 10^{-13}$ & 0.21 & 0.32 & 0.35 & $\begin{array}{c}3.3 \times 10^{-8} \\
\left(1.4 \times 10^{-8}\right)\end{array}$ & $5.0 \times 10^{-1.3}$ \\
\hline 2,4-DNT & 0.056 & 0.11 & 0.082 & $\begin{array}{c}7.7 \times 10^{-9} \\
\left(3.3 \times 10^{-9}\right)\end{array}$ & $\begin{array}{c}2.1 \times 10^{-9} \\
\left(9.0 \times 10^{-10}\right)\end{array}$ & $1.2 \times 10^{-13}$ & 0.16 & 0.29 & 0.29 & $\begin{array}{c}2.7 \times 10^{-8} \\
\left(9.7 \times 10^{-9}\right)\end{array}$ & $4.1 \times 10^{-13}$ \\
\hline 2,6-DNT & 0.043 & 0.053 & 0.056 & $\begin{array}{c}1.2 \times 10^{-9} \\
\left(2.3 \times 10^{-9}\right)\end{array}$ & $\begin{array}{c}1.4 \times 10^{-9} \\
\left(6.2 \times 10^{-10}\right)\end{array}$ & $1.8 \times 10^{-14}$ & 0.10 & 0.073 & 0.13 & $\begin{array}{c}7.4 \times 10^{-10} \\
\left(3.2 \times 10^{-10}\right)\end{array}$ & $1.1 \times 10^{-14}$ \\
\hline Nitrobenzene & - & - & - & - & - & - & 0.10 & 0.077 & 0.10 & $8.7 \times 10^{-11}$ & $1.3 \times 10^{-15}$ \\
\hline PCBs & 0.46 & 0.93 & 1.1 & $\begin{array}{c}1.0 \times 10^{-7} \\
\left(4.4 \times 10^{-8}\right)\end{array}$ & $\begin{array}{c}1.4 \times 10^{-8} \\
\left(6.0 \times 10^{-9}\right)\end{array}$ & $\begin{array}{c}1.6 \times 10^{-12} \\
\left(6.9 \times 10^{-13}\right)\end{array}$ & 0.27 & 0.20 & 0.61 & $\begin{array}{c}5.8 \times 10^{-8} \\
\left(2.4 \times 10^{-8}\right)\end{array}$ & $\begin{array}{r}8.6 \times 10^{-13} \\
\left(3.7 \times 10^{-13}\right)\end{array}$ \\
\hline PAHs & 0.052 & 0.11 & 0.088 & $\begin{array}{c}8.3 \times 10^{-9} \\
\left(3.5 \times 10^{-9}\right)\end{array}$ & $\begin{array}{c}1.2 \times 10^{-9} \\
\left(6.0 \times 10^{-10}\right)\end{array}$ & $1.2 \times 10^{-13}$ & - & - & - & - & - \\
\hline
\end{tabular}

a Values in parentheses represent carcinogenic intake for the parameter; values not in parentheses represent noncarcinogenic intake for the parameter. Dermal intakes were calculated for soils only (see Section 3.2 for rationale)

b Exposure point concentration (EPC) $=95 \%$ upper confidence limit (UCL) of the arithmetic average based on all data collected from the quarry proper.

c A hyphen (-) indicates the parameter was not detected. 
TABLE 3.4 Exposure Point Concentrations and Estimated Radiological Contaminant Intakes for a Recreational Visitor at the Quarry Proper ${ }^{\mathrm{a}}$

\begin{tabular}{|c|c|c|c|c|c|c|c|c|}
\hline \multirow[b]{2}{*}{$\begin{array}{c}\text { Exposure } \\
\text { Unit }\end{array}$} & \multirow[b]{2}{*}{ Radionuclide } & \multicolumn{3}{|c|}{ Concentration $(\mathrm{pCi} / \mathrm{g})$} & \multicolumn{4}{|c|}{ Intake } \\
\hline & & Mean & $\begin{array}{l}\text { Standard } \\
\text { Deviation }\end{array}$ & $\mathrm{EPC}^{\mathrm{b}}$ & $\begin{array}{l}\text { External } \\
(\mathrm{pCi}-\mathrm{yr} / \mathrm{g})\end{array}$ & $\begin{array}{l}\text { Ingestion } \\
\text { (pCi) }\end{array}$ & $\begin{array}{c}\text { Inhalation } \\
\text { (pCi) }\end{array}$ & $\begin{array}{c}\text { Dermal }^{\mathrm{d}} \\
(\mathrm{pCi})\end{array}$ \\
\hline \multirow[t]{5}{*}{ Soil } & Radium-226 & 2.4 & 6.9 & 3.2 & 0.87 & $2.3 \times 10^{2}$ & $3.4 \times 10^{-3}$ & 62 \\
\hline & Radium-228 & 2.3 & 10 & 3.4 & 0.94 & $2.5 \times 10^{2}$ & $3.7 \times 10^{-3}$ & 66 \\
\hline & Thorium-230 & 30 & 190 & 59 & 16 & $4.3 \times 10^{3}$ & $6.5 \times 10^{-2}$ & 1.2 \\
\hline & Thorium-232 & 1.5 & 3.0 & 2.1 & 0.57 & $1.5 \times 10^{2}$ & $2.3 \times 10^{-3}$ & $4.1 \times 10^{-2}$ \\
\hline & Uranium-238 & 4.8 & 7.5 & 5.7 & 1.6 & $4.1 \times 10^{2}$ & $6.2 \times 10^{-3}$ & 1.1 \\
\hline \multirow[t]{5}{*}{ Fractures } & Radium-226 & 4.5 & 7.8 & 6.3 & 1.7 & $4.5 \times 10^{2}$ & $6.8 \times 10^{-3}$ & $\mathrm{NA}$ \\
\hline & Radium-228 & 4.6 & 9.7 & 6.8 & 1.9 & $4.9 \times 10^{2}$ & $7.5 \times 10^{-3}$ & NA \\
\hline & Thorium-230 & 58 & 120 & 88 & 24 & $6.3 \times 10^{3}$ & $9.5 \times 10^{-2}$ & NA \\
\hline & Thorium-232 & 5.7 & 12 & 9.5 & 2.6 & $6.8 \times 10^{2}$ & $1.0 \times 10^{-2}$ & NA \\
\hline & Uranium-238 & 17 & 29 & 24 & 6.5 & $1.7 \times 10^{3}$ & $2.6 \times 10^{-2}$ & NA \\
\hline
\end{tabular}

a For the quarry pond, uranium was identified as the only COPC. Ingestion of surface water was evaluated using the maximum concentration of $540 \mathrm{pCi} / \mathrm{L}$. The estimated combined intake from ingestion and dermal contact was $6.6 \times 10^{4} \mathrm{pCi}$.

b Exposure point concentration $(\mathrm{EPC})=95 \%$ upper confidence limit (UCL) of the arithmetic average based on all data collected from the quarry proper.

c The radiological dose from external radiation (in units of mrem) was calculated using the average of exposure rate measurements $(17 \mu \mathrm{R} / \mathrm{h})$ in the quarry. The estimated dose was $39 \mathrm{mrem}$.

d Dermal intakes were calculated for soils only (see Section 3.2 for rationale). 
TABLE 3.5 Exposure Point Concentrations and Estimated Contaminant Intakes for a Recreational Visitor from Exposure to Surface Water and Sediment at Femme Osage Slough

\begin{tabular}{|c|c|c|c|c|c|c|c|c|c|}
\hline \multirow[b]{3}{*}{ Contaminant } & \multirow{3}{*}{$\begin{array}{c}\mathrm{EPC}^{\mathrm{i}} \\
(\mathrm{pCi} / \mathrm{L}) \\
\end{array}$} & \multicolumn{2}{|c|}{ Surface Water } & \multicolumn{6}{|c|}{ Sediment } \\
\hline & & \multicolumn{2}{|c|}{ Intake $^{h}(\mathrm{pCi})$} & \multicolumn{3}{|c|}{ Concentration (pCi/g) } & \multicolumn{3}{|c|}{ Intake $^{\mathrm{b}}(\mathrm{pCi})$} \\
\hline & & Ingestion & Dermal & Mean & StDev ${ }^{\mathrm{c}}$ & $\mathrm{UCL}^{\mathrm{d}}$ & Ingestion & Dermal & Inhalation \\
\hline \multicolumn{10}{|l|}{ Radionuclides } \\
\hline Uranium, total & 53 & $6.4 \times 10^{3}$ & $1.3 \times 10^{2}$ & $3.2^{\mathrm{c}}$ & 1.2 & 4.5 & $3.2 \times 10^{2}$ & $8.9 \times 10^{-1}$ & $4.9 \times 10^{-3}$ \\
\hline & \multirow{3}{*}{$\begin{array}{c}\text { Exposure Point } \\
\text { Concentration } \\
(\mathrm{mg} / \mathrm{L})\end{array}$} & \multicolumn{2}{|c|}{ Surface Water } & \multicolumn{6}{|c|}{ Sediment } \\
\hline & & \multicolumn{2}{|c|}{ Intake $^{b}(\mathrm{mg} / \mathrm{kg}-\mathrm{d})$} & \multicolumn{3}{|c|}{ Concentration (mg/kg) } & \multicolumn{3}{|c|}{ Intake $^{\mathrm{h}}(\mathrm{mg} / \mathrm{kg}-\mathrm{d})$} \\
\hline Contaminant & & Ingestion & Dermal & Mean & StDev $^{\mathrm{c}}$ & $\mathrm{UCL}^{\mathrm{d}}$ & Ingestion & Dermal & Inhalation \\
\hline \multicolumn{10}{|l|}{ Chemicals } \\
\hline \multicolumn{10}{|l|}{ Metals } \\
\hline Aluminum & 7.0 & $1.1 \times 10^{-3}$ & $2.3 \times 10^{-5}$ & 12,000 & 5,100 & 15,000 & $1.4 \times 10^{-3}$ & $1.9 \times 10^{-5}$ & $2.1 \times 10^{-8}$ \\
\hline Antimony & $-{ }^{f}$ & - & - & 12 & 8.1 & 16 & $1.5 \times 10^{-6}$ & $2.1 \times 10^{-8}$ & $2.3 \times 10^{-11}$ \\
\hline Arsenic & 0.0087 & $\begin{array}{c}1.4 \times 10^{-6} \\
\left(5.8 \times 10^{-7}\right)\end{array}$ & $\begin{array}{c}2.9 \times 10^{-8} \\
\left(1.2 \times 10^{-8}\right)\end{array}$ & - & - & - & - & - & - \\
\hline Beryllium & - & - & - & 1.2 & 0.30 & 1.4 & $\begin{array}{r}1.3 \times 10^{-7} \\
\left(5.8 \times 10^{-8}\right)\end{array}$ & $\begin{array}{c}9.0 \times 10^{-10} \\
\left(3.9 \times 10^{-10}\right)\end{array}$ & $\begin{array}{c}1.9 \times 10^{-12} \\
\left(8.3 \times 10^{-13}\right)\end{array}$ \\
\hline Cadmium & - & - & - & 1.1 & 1.0 & 1.3 & $1.3 \times 10^{-7}$ & $8.3 \times 10^{.4}$ & $\begin{array}{c}1.9 \times 10^{-12} \\
\left(8.2 \times 10^{-13}\right)\end{array}$ \\
\hline Chromium & - & - & - & 16 & 11 & 19 & $1.8 \times 10^{-6}$ & $2.4 \times 10^{-7}$ & $\begin{array}{c}2.7 \times 10^{-11} \\
\left(1.1 \times 10^{-11}\right)\end{array}$ \\
\hline Copper & 0.011 & $1.7 \times 10^{-6}$ & $3.6 \times 10^{-8}$ & 21 & 5.3 & 24 & $2.3 \times 10^{-6}$ & $1.5 \times 10^{-6}$ & $3.4 \times 10^{-11}$ \\
\hline Manganese & - & - & - & 740 & 180 & 840 & $7.9 \times 10^{-5}$ & $1.5 \times 10^{-5}$ & $1.2 \times 10^{-9}$ \\
\hline Mercury & - & - & - & 0.07 & 0.14 & 0.10 & $9.6 \times 10^{-9}$ & $2.6 \times 10^{-10}$ & $1.4 \times 10^{-13}$ \\
\hline Molybdenum & - & - & - & 1.5 & 0.91 & 2.0 & $1.9 \times 10^{-7}$ & $1.3 \times 10^{-8}$ & $2.8 \times 10^{-12}$ \\
\hline Nickel & 0.014 & $2.1 \times 10^{-6}$ & $4.5 \times 10^{-8}$ & 21 & 3.7 & 23 & $2.2 \times 10^{-6}$ & $1.5 \times 10^{-7}$ & $3.3 \times 10^{-11}$ \\
\hline Selenium & - & - & - & 2.6 & 5.6 & 3.9 & $3.6 \times 10^{-7}$ & $2.5 \times 10^{-8}$ & $5.5 \times 10^{-12}$ \\
\hline Strontium & 0.26 & $4.0 \times 10^{-5}$ & $8.4 \times 10^{-7}$ & 50 & 14 & 58 & $5.4 \times 10^{-6}$ & $7.5 \times 10^{-8}$ & $8.2 \times 10^{-11}$ \\
\hline
\end{tabular}


TABLE 3.5 (Cont.)

\begin{tabular}{|c|c|c|c|c|c|c|c|c|c|}
\hline \multirow[b]{3}{*}{ Contaminant } & \multirow{3}{*}{$\begin{array}{c}\mathrm{EPC}^{\mathrm{a}} \\
(\mathrm{mg} / \mathrm{L})\end{array}$} & \multicolumn{2}{|c|}{ Surface Water } & \multicolumn{6}{|c|}{ Sediment } \\
\hline & & \multicolumn{2}{|c|}{ Intake $^{\mathrm{h}}(\mathrm{mg} / \mathrm{kg} \cdot \mathrm{d})$} & \multicolumn{3}{|c|}{ Concentration (mg/kg) } & \multicolumn{3}{|c|}{ Intake $^{b}(\mathrm{mg} / \mathrm{kg}-\mathrm{d})$} \\
\hline & & Ingestion & Dermal & Mean & StDev ${ }^{c}$ & $\mathrm{UCL}^{\mathrm{d}}$ & Ingestion & Dermal & Inhalation \\
\hline \multicolumn{10}{|l|}{ Chemicals (Cont.) } \\
\hline \multicolumn{10}{|l|}{ Metals (cont.) } \\
\hline Uranium & 0.078 & $1.2 \times 10^{-5}$ & $2.6 \times 10^{-7}$ & 9.6 & 3.6 & 13 & $1.2 \times 10^{-6}$ & $3.3 \times 10^{-9}$ & $1.8 \times 10^{-11}$ \\
\hline Vanadium & - & - & - & 31 & 8.5 & 36 & $3.4 \times 10^{-6}$ & $4.6 \times 10^{-8}$ & $5.1 \times 10^{-11}$ \\
\hline Zinc & 0.085 & $1.3 \times 10^{-5}$ & $2.8 \times 10^{-7}$ & 68 & 37 & 77 & $7.2 \times 10^{-6}$ & $4.9 \times 10^{-6}$ & $1.1 \times 10^{-10}$ \\
\hline \multicolumn{10}{|c|}{ Nitroaromatic compounds } \\
\hline $1,3,5-\mathrm{TNB}$ & 0.000040 & $6.3 \times 10^{-9}$ & $1.3 \times 10^{-10}$ & 0.012 & 0.032 & 0.025 & $2.4 \times 10^{-9}$ & $6.4 \times 10^{-10}$ & $3.6 \times 10^{-10}$ \\
\hline 1,3-DNB & - & - & - & 0.0044 & 0.0051 & 0.0065 & $6.1 \times 10^{-10}$ & $1.7 \times 10^{-10}$ & $9.2 \times 10^{-11}$ \\
\hline $2,4,6-\mathrm{TNT}$ & 0.000067 & $\begin{array}{c}1.0 \times 10^{-8} \\
\left(4.5 \times 10^{-9}\right)\end{array}$ & $\begin{array}{c}2.2 \times 10^{-10} \\
\left(9.4 \times 10^{-11}\right)\end{array}$ & 0.12 & 0.32 & 0.25 & $\begin{array}{r}9.4 \times 10^{-10} \\
\left(4.0 \times 10^{-10}\right)\end{array}$ & $\begin{array}{c}6.4 \times 10^{-9} \\
\left(2.7 \times 10^{-9}\right)\end{array}$ & $\begin{array}{r}3.6 \times 10^{-10} \\
\left(1.5 \times 10^{-10}\right)\end{array}$ \\
\hline 2,4-DNT & 0.000037 & $\begin{array}{c}5.8 \times 10^{-9} \\
\left(2.5 \times 10^{-9}\right)\end{array}$ & $\begin{array}{c}1.2 \times 10^{-10} \\
\left(5.2 \times 10^{-11}\right)\end{array}$ & 0.0044 & 0.0051 & 0.0065 & $\begin{array}{c}6.1 \times 10^{-10} \\
\left(2.6 \times 10^{-10}\right)\end{array}$ & $\begin{array}{c}1.7 \times 10^{-10} \\
\left(7.2 \times 10^{-11}\right)\end{array}$ & $\begin{array}{r}9.2 \times 10^{-11} \\
\left(3.9 \times 10^{-12}\right)\end{array}$ \\
\hline 2.6-DNT & 0.000026 & $\begin{array}{c}4.1 \times 10^{-9} \\
\left(1.7 \times 10^{-9}\right)\end{array}$ & $\begin{array}{c}8.6 \times 10^{-11} \\
\left(3.7 \times 10^{-11}\right)\end{array}$ & 0.12 & 0.32 & 0.25 & $\begin{array}{c}1.9 \times 10^{-9} \\
\left(8.1 \times 10^{-10}\right)\end{array}$ & $\begin{array}{c}6.4 \times 10^{-9} \\
\left(2.7 \times 10^{-9}\right)\end{array}$ & $\begin{array}{r}3.6 \times 10^{-10} \\
\left(1.5 \times 10^{-10}\right)\end{array}$ \\
\hline Nitrobenzene & - & - & - & 0.12 & 0.32 & 0.25 & $9.4 \times 10^{-10}$ & $6.4 \times 10^{-9}$ & $3.6 \times 10^{-11}$ \\
\hline
\end{tabular}

a Exposure point concentration (EPC) is the maximum concentration reported for the parameter. The uranium value is maximum concentration reported in samples collected since 1995 .

b Values in parentheses represent carcinogenic intake for the parameter; values not in parentheses represent noncarcinogenic intake for the parameter.

c StDev $=$ standard deviation.

d Intakes were calculated using the UCL as the exposure point concentration. UCL $=95 \%$ upper confidence limit of the arithmetic average; the UCLs are based on all data collected from the slough.

c Uranium-238.

if A hyphen (-) indicates the parameter is not a COPC for that medium. 
TABLE 3.6 Exposure Point Concentrations and Estimated Contaminant Intakes for Ingestion of Fish from Femme Osage Slough

\begin{tabular}{lcc}
\hline Contaminant & $\begin{array}{c}\mathrm{EPC}^{\mathrm{a}} \\
(\mathrm{pCi} / \mathrm{g})\end{array}$ & $\begin{array}{c}\text { Intake } \\
(\mathrm{pCi})\end{array}$ \\
\hline $\begin{array}{l}\text { Radionuclides } \\
\text { Uranium, total }\end{array}$ & 0.0057 & 190 \\
\hline & & \\
$\quad$ Contaminant & $\begin{array}{c}\mathrm{EPC} \\
(\mathrm{mg} / \mathrm{kg})\end{array}$ & $\begin{array}{c}\text { Intake } \\
(\mathrm{mg} / \mathrm{kg}-\mathrm{d})\end{array}$ \\
\hline Chemicals & & \\
Metals & & \\
$\quad$ Arsenic & 0.085 & $3.7 \times 10^{-6}$ \\
$\quad$ Lead & & $\left(1.6 \times 10^{-6}\right)^{\mathrm{b}}$ \\
$\quad$ Mercury & 0.83 & $3.6 \times 10^{-5}$ \\
$\quad$ Uranium & 0.14 & $6.0 \times 10^{-6}$ \\
\hline
\end{tabular}

a Exposure point concentration $(E P C)=$ maximum detected concentration in the edible portion of fish.

b Estimated daily intake averaged over a lifetime of 70 years. 
TABLE 3.7 Estimated Intakes of Uranium for a Hypothetical Future Resident

\begin{tabular}{|c|c|c|c|c|c|c|c|}
\hline \multirow[b]{3}{*}{ Well ID } & \multicolumn{3}{|c|}{ Uranium } & \multirow[b]{3}{*}{ Well ID } & \multicolumn{3}{|c|}{ Uranium } \\
\hline & \multirow[b]{2}{*}{$\begin{array}{c}\mathrm{EPC}^{\mathrm{a}} \\
(\mathrm{pCi} / \mathrm{L})\end{array}$} & \multicolumn{2}{|c|}{ Intake $(\mathrm{pCi})$} & & \multirow[b]{2}{*}{$\begin{array}{c}\mathrm{EPC}^{\mathrm{a}} \\
(\mathrm{pCi} / \mathrm{L})\end{array}$} & \multicolumn{2}{|c|}{ Intake (pCi) } \\
\hline & & Ingestion & Dermal & & & Ingestion & Dermal \\
\hline North of Slough & & & & South of Sloug & & & \\
\hline$M W-1002$ & 3.6 & $7.6 \times 10^{4}$ & $1.3 \times 10^{2}$ & $M W-1010$ & 0.44 & $9.3 \times 10^{3}$ & $1.5 \times 10^{1}$ \\
\hline MW-1004 & 3,500 & $7.4 \times 10^{7}$ & $1.3 \times 10^{5}$ & MW-1011 & 5.6 & $1.2 \times 10^{5}$ & $2.0 \times 10^{2}$ \\
\hline MW-1005 & 2,200 & $4.6 \times 10^{7}$ & $7.7 \times 10^{4}$ & MW-1017 & 1.5 & $3.2 \times 10^{4}$ & $5.3 \times 10^{1}$ \\
\hline MW-1006 & 3,100 & $6.5 \times 10^{7}$ & $1.1 \times 10^{5}$ & MW-1018 & 1.8 & $3.8 \times 10^{4}$ & $6.3 \times 10^{1}$ \\
\hline MW-1007 & 61 & $1.3 \times 10^{6}$ & $2.1 \times 10^{3}$ & MW-1019 & 5.1 & $1.1 \times 10^{5}$ & $1.8 \times 10^{2}$ \\
\hline MW-1008 & 3,500 & $7.3 \times 10^{7}$ & $1.2 \times 10^{5}$ & MW-1020 & 4.5 & $9.4 \times 10^{4}$ & $1.6 \times 10^{2}$ \\
\hline MW-1009 & 15 & $3.2 \times 10^{5}$ & $5.3 \times 10^{2}$ & MW-1021 & 0.90 & $1.9 \times 10^{4}$ & $3.2 \times 10^{1}$ \\
\hline MW-1013 & 930 & $2.0 \times 10^{7}$ & $3.3 \times 10^{4}$ & MW-1022 & 0.90 & $1.9 \times 10^{4}$ & $3.2 \times 10^{1}$ \\
\hline MW-1014 & 1,100 & $2.4 \times 10^{7}$ & $3.7 \times 10^{4}$ & MW-1023 & 1.8 & $3.8 \times 10^{4}$ & $6.3 \times 10^{1}$ \\
\hline MW-1015 & 330 & $7.0 \times 10^{6}$ & $1.2 \times 10^{4}$ & MW-1033 & 3.7 & $7.9 \times 10^{4}$ & $1.3 \times 10^{2}$ \\
\hline MW-1016 & 200 & $4.3 \times 10^{6}$ & $7.0 \times 10^{3}$ & MW-1044 & 0.31 & $6.5 \times 10^{3}$ & $1.1 \times 10^{1}$ \\
\hline MW-1026 & 0.10 & $2.2 \times 10^{3}$ & 3.5 & RMW-1 & 1.5 & $3.2 \times 10^{4}$ & $5.3 \times 10^{1}$ \\
\hline MW-1027 & 430 & $9.0 \times 10^{6}$ & $1.5 \times 10^{4}$ & RMW-2 & 6.8 & $1.4 \times 10^{5}$ & $2.4 \times 10^{2}$ \\
\hline$M W-1028$ & 3.2 & $6.5 \times 10^{4}$ & $1.1 \times 10^{2}$ & RMW-3 & 1.1 & $2.3 \times 10^{4}$ & $3.9 \times 10^{1}$ \\
\hline MW-1029 & 2.2 & $4.5 \times 10^{4}$ & $7.7 \times 10^{1}$ & RMW-4 & 2.5 & $5.4 \times 10^{4}$ & $8.8 \times 10^{1}$ \\
\hline MW-1030 & 63 & $1.3 \times 10^{6}$ & $2.2 \times 10^{3}$ & & & & \\
\hline MW-1031 & 170 & $3.6 \times 10^{6}$ & $6.0 \times 10^{3}$ & & & & \\
\hline MW-1032 & 1,000 & $2.2 \times 10^{7}$ & $3.5 \times 10^{4}$ & & & & \\
\hline MW-1035 & 0.56 & $1.2 \times 10^{4}$ & $2.0 \times 10^{1}$ & & & & \\
\hline MW-1036 & 7.8 & $1.6 \times 10^{5}$ & $2.7 \times 10^{2}$ & & & & \\
\hline MW-1037 & 2.1 & $4.3 \times 10^{4}$ & $7.4 \times 10^{1}$ & & & & \\
\hline MW-1038 & 3.9 & $8.2 \times 10^{4}$ & $1.4 \times 10^{2}$ & & & & \\
\hline MW-1039 & 0.62 & $1.3 \times 10^{4}$ & $2.2 \times 10^{1}$ & & & & \\
\hline MW-1040 & 6.6 & $1.4 \times 10^{5}$ & $2.3 \times 10^{2}$ & & & & \\
\hline MW-1041 & 4.5 & $9.5 \times 10^{4}$ & $1.6 \times 10^{2}$ & & & & \\
\hline MW-1045 & 5.8 & $1.2 \times 10^{5}$ & $2.0 \times 10^{2}$ & & & & \\
\hline MW-1046 & 28 & $5.9 \times 10^{5}$ & $9.8 \times 10^{3}$ & & & & \\
\hline MW-1047 & 3.0 & $6.3 \times 10^{4}$ & $1.1 \times 10^{2}$ & & & & \\
\hline MW-1048 & 200 & $4.3 \times 10^{6}$ & $7.0 \times 10^{3}$ & & & & \\
\hline MW-1049 & 0.50 & $1.1 \times 10^{4}$ & $1.8 \times 10^{1}$ & & & & \\
\hline
\end{tabular}

a Exposure point concentration (EPC) $=$ upper confidence limit (UCL) of the arithmetic average or the maximum value reported for uranium for each well from the data collected since 1995. 
TABLE 3.8 Estimated Noncarcinogenic Intakes of Metal COPCs for a Hypothetical Future Resident

\begin{tabular}{|c|c|c|c|c|c|c|c|c|c|c|c|c|}
\hline \multirow[b]{3}{*}{ Well ID } & \multicolumn{3}{|c|}{ Barium } & \multicolumn{3}{|c|}{ Cadmium } & \multicolumn{3}{|c|}{ Chromium } & \multicolumn{3}{|c|}{ Copper } \\
\hline & \multirow[b]{2}{*}{$\begin{array}{c}\mathrm{EPC}^{\mathrm{a}} \\
(\mu \mathrm{L} / \mathrm{L})\end{array}$} & \multicolumn{2}{|c|}{ Intake (mg/kg-d) } & \multirow[b]{2}{*}{$\begin{array}{c}\mathrm{EPC}^{\mathrm{a}} \\
(\mu \mathrm{g} / \mathrm{L})\end{array}$} & \multicolumn{2}{|c|}{ Intake (mg/kg-d) } & \multirow[b]{2}{*}{$\begin{array}{c}\mathrm{EPC}^{\mathrm{a}} \\
(\mu \mathrm{g} / \mathrm{L})\end{array}$} & \multicolumn{2}{|c|}{ Intake (mg/kg-d) } & \multirow[b]{2}{*}{$\begin{array}{l}\mathrm{EPC}^{\mathrm{a}} \\
(\mu \mathrm{g} / \mathrm{L})\end{array}$} & \multicolumn{2}{|c|}{ Intake (mg/kg-d) } \\
\hline & & Ingestion & Dermal & & Ingestion & Dermal & & Ingestion & Dermal & & Ingestion & Dermal \\
\hline \multicolumn{13}{|c|}{ North of Slough } \\
\hline MW-1002 & 120 & $3.2 \times 10^{-3}$ & $5.1 \times 10^{-6}$ & $\mathrm{NC}^{\mathrm{b}}$ & $-^{b}$ & - & 4.0 & $1.1 \times 10^{-4}$ & $1.8 \times 10^{-7}$ & $\mathrm{NC}$ & - & - \\
\hline$M W-1004$ & 79 & $2.2 \times 10^{-3}$ & $3.5 \times 10^{-6}$ & NC & - & - & NC & - & - & 10 & $2.8 \times 10^{-4}$ & $4.5 \times 10^{-7}$ \\
\hline MW-1005 & $\mathrm{NS}^{\mathrm{b}}$ & - & - & NS & - & - & NS & - & - & NS & $\begin{array}{c}2.0 \times 10 \\
-\end{array}$ & $\begin{array}{l}4.0 \times 10 \\
-\end{array}$ \\
\hline MW-1006 & 76 & $2.1 \times 10^{-3}$ & $3.3 \times 10^{-6}$ & 3.1 & $8.4 \times 10^{-5}$ & $1.3 \times 10^{-7}$ & 2.8 & $7.8 \times 10^{-5}$ & $1.2 \times 10^{-7}$ & 25 & $6.9 \times 10^{-4}$ & $1.1 \times 10^{-6}$ \\
\hline MW- 1007 & 330 & $9.1 \times 10^{-3}$ & $1.5 \times 10^{-5}$ & NC & - & - & NC & - & - & 25 & $6.9 \times 10^{-4}$ & $1.1 \times 10^{-6}$ \\
\hline MW- 1008 & 81 & $2.2 \times 10^{-3}$ & $3.6 \times 10^{-6}$ & $\mathrm{NC}$ & - & - & $\mathrm{NC}$ & - & - & 33 & $8.9 \times 10^{-4}$ & $1.4 \times 10^{-6}$ \\
\hline MW- 1009 & 470 & $1.3 \times 10^{-2}$ & $2.1 \times 10^{-5}$ & NC & - & - & $\mathrm{NC}$ & - & - & 16 & $4.4 \times 10^{-4}$ & $7.0 \times 10^{-7}$ \\
\hline$M W-1013$ & 200 & $5.3 \times 10^{-3}$ & $8.5 \times 10^{-6}$ & $\mathrm{NC}$ & - & - & $\mathrm{NC}$ & - & - & $\mathrm{NC}$ & - & - \\
\hline MW-1014 & 140 & $3.7 \times 10^{-3}$ & $5.9 \times 10^{-6}$ & NC & - & - & $\mathrm{NC}$ & - & - & 4.9 & $1.3 \times 10^{-4}$ & $2.1 \times 10^{-7}$ \\
\hline MW-1015 & $\begin{array}{l}140 \\
270\end{array}$ & $7.3 \times 10^{-3}$ & $1.2 \times 10^{-5}$ & $\mathrm{NC}$ & - & - & $\mathrm{NC}$ & - & - & $\begin{array}{l}4.9 \\
17\end{array}$ & $\begin{array}{l}1.3 \times 10^{-4} \\
4.5 \times 10^{-1}\end{array}$ & $7.2 \times 10^{-7}$ \\
\hline MW-1016 & 170 & $4.6 \times 10^{-3}$ & $7.4 \times 10^{-6}$ & NC & - & - & 6.4 & $1.8 \times 10^{-4}$ & $2.8 \times 10^{-7}$ & 18 & $4.8 \times 10^{-4}$ & $7.7 \times 10^{-7}$ \\
\hline MW- 1026 & 400 & $1.1 \times 10^{-2}$ & $1.7 \times 10^{-5}$ & $\mathrm{NC}$ & - & - & NC & - & - & 18 & $4.9 \times 10^{-4}$ & $7.8 \times 10^{-7}$ \\
\hline MW-1027 & 120 & $3.3 \times 10^{-3}$ & $5.3 \times 10^{-6}$ & $\mathrm{NC}$ & - & - & 5.3 & $1.5 \times 10^{-4}$ & $2.3 \times 10^{-7}$ & 18 & $4.8 \times 10^{-4}$ & $7.7 \times 10^{-7}$ \\
\hline MW-1028 & 350 & $9.7 \times 10^{-3}$ & $1.6 \times 10^{-5}$ & $\mathrm{NC}$ & - & - & $\mathrm{NC}$ & - & - & $\mathrm{NC}$ & - & - \\
\hline MW- 1029 & 110 & $3.1 \times 10^{-3}$ & $4.9 \times 10^{-5}$ & $\mathrm{NC}$ & - & - & 7.4 & $2.0 \times 10^{-4}$ & $3.2 \times 10^{-7}$ & 27 & $7.5 \times 10^{-4}$ & $1.2 \times 10^{-6}$ \\
\hline MW- 1030 & 180 & $4.9 \times 10^{-3}$ & $7.9 \times 10^{-6}$ & 3.5 & $9.7 \times 10^{-5}$ & $1.6 \times 10^{-7}$ & 92 & $2.5 \times 10^{-3}$ & $4.6 \times 10^{-6}$ & 24 & $6.6 \times 10^{-4}$ & $1.1 \times 10^{-6}$ \\
\hline$M W-1031$ & 110 & $2.9 \times 10^{-3}$ & $4.6 \times 10^{-6}$ & $\mathrm{NC}$ & - & - & $\mathrm{NC}$ & - & - & NC & - & - \\
\hline$M W-1032$ & 96 & $2.6 \times 10^{-3}$ & $4.2 \times 10^{-6}$ & NC & - & - & NC & - & - & 6.9 & $1.9 \times 10^{-4}$ & $3.0 \times 10^{-7}$ \\
\hline MW-1035 & 300 & $8.3 \times 10^{-3}$ & $1.3 \times 10^{-5}$ & 0.56 & $1.5 \times 10^{-5}$ & $2.5 \times 10^{-8}$ & 11 & $2.9 \times 10^{-4}$ & $4.7 \times 10^{-7}$ & $\mathrm{NC}$ & - & - \\
\hline MW-1036 & 250 & $6.7 \times 10^{-3}$ & $1.1 \times 10^{-5}$ & 0.26 & $7.1 \times 10^{-6}$ & $1.1 \times 10^{-8}$ & 9.3 & $2.5 \times 10^{-4}$ & $4.1 \times 10^{-7}$ & 5.9 & $1.6 \times 10^{-4}$ & $2.6 \times 10^{-7}$ \\
\hline MW-1037 & 410 & $1.1 \times 10^{-2}$ & $1.8 \times 10^{-5}$ & 0.34 & $9.3 \times 10^{-6}$ & $1.5 \times 10^{-8}$ & 19 & $5.3 \times 10^{-4}$ & $8.5 \times 10^{-7}$ & 11 & $3.0 \times 10^{-4}$ & $4.8 \times 10^{-7}$ \\
\hline MW-1038 & 380 & $1.0 \times 10^{-2}$ & $1.6 \times 10^{-5}$ & $\mathrm{NC}$ & - & - & 9.6 & $2.6 \times 10^{-4}$ & $4.2 \times 10^{-7}$ & 14 & $3.8 \times 10^{-4}$ & $6.1 \times 10^{-7}$ \\
\hline MW- 1039 & 530 & $1.5 \times 10^{-2}$ & $2.3 \times 10^{-5}$ & $\mathrm{NC}$ & - & - & 5,4 & $1.5 \times 10^{-4}$ & $2.4 \times 10^{-7}$ & 8.6 & $2.4 \times 10^{-4}$ & $3.8 \times 10^{-7}$ \\
\hline MW- 1040 & 380 & $1.0 \times 10^{-2}$ & $1.7 \times 10^{-5}$ & 2.1 & $5.9 \times 10^{-5}$ & $9.4 \times 10^{-8}$ & 18 & $4.9 \times 10^{-4}$ & $7.9 \times 10^{-7}$ & 24 & $6.5 \times 10^{-4}$ & $1.0 \times 10^{-6}$ \\
\hline$M W-1041$ & 430 & $1.2 \times 10^{-2}$ & $1.9 \times 10^{-5}$ & 2.7 & $7.3 \times 10^{-5}$ & $1.2 \times 10^{-7}$ & 9.5 & $2.6 \times 10^{-4}$ & $4.2 \times 10^{-7}$ & NC & - & 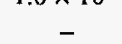 \\
\hline MW-1045 & 320 & $8.8 \times 10^{-3}$ & $1.4 \times 10^{-5}$ & $\mathrm{NC}$ & - & $\begin{array}{c}1,2 \times 10 \\
-\end{array}$ & 8.7 & $2.4 \times 10^{-4}$ & $3.8 \times 10^{-7}$ & 36 & $9.9 \times 10^{-4}$ & $1.6 \times 10^{-6}$ \\
\hline$M W-1046$ & 220 & $6.1 \times 10^{-3}$ & $9.8 \times 10^{-6}$ & $\mathrm{NC}$ & - & - & 11 & $3.1 \times 10^{-4}$ & $4.9 \times 10^{-7}$ & 37 & $1.0 \times 10^{-3}$ & $1.6 \times 10^{-6}$ \\
\hline MW-1047 & 600 & $1.7 \times 10^{-2}$ & $2.6 \times 10^{-5}$ & $\mathrm{NC}$ & - & - & 14 & $3.8 \times 10^{-4}$ & $6.0 \times 10^{-7}$ & 35 & $9.5 \times 10^{-4}$ & $1.5 \times 10^{-6}$ \\
\hline$M W-1048$ & 460 & $1.3 \times 10^{-2}$ & $2.0 \times 10^{-5}$ & $\mathrm{NC}$ & - & - & 11 & $3.0 \times 10^{-4}$ & $4.7 \times 10^{-7}$ & 120 & $3.2 \times 10^{-4}$ & $5.1 \times 10^{-6}$ \\
\hline MW-1049 & 1,200 & $3.4 \times 10^{-2}$ & $5.4 \times 10^{-5}$ & $\mathrm{NC}$ & - & - & 8.4 & $2.3 \times 10^{-4}$ & $3.7 \times 10^{-7}$ & 22 & $5.9 \times 10^{-4}$ & $9.5 \times 10^{-7}$ \\
\hline
\end{tabular}


TABLE 3.8 (Cont.)

\begin{tabular}{|c|c|c|c|c|c|c|c|c|c|c|c|c|}
\hline \multirow[b]{3}{*}{ Well ID } & \multicolumn{3}{|c|}{ Manganese } & \multicolumn{3}{|c|}{ Mercury } & \multicolumn{3}{|c|}{ Nickel } & \multicolumn{3}{|c|}{ Thallium } \\
\hline & \multirow[b]{2}{*}{$\begin{array}{l}E P C^{a} \\
(\mu \mathrm{g} / \mathrm{L})\end{array}$} & \multicolumn{2}{|c|}{ Intake (mg/kg-d) } & \multirow[b]{2}{*}{$\begin{array}{c}\mathrm{EPC}^{\mathrm{a}} \\
(\mu \mathrm{g} / \mathrm{L})\end{array}$} & \multicolumn{2}{|c|}{ Intake (mg/kg-d) } & \multirow[b]{2}{*}{$\begin{array}{c}\mathrm{EPC}^{\mathrm{a}} \\
(\mu \mathrm{g} / \mathrm{L})\end{array}$} & \multicolumn{2}{|c|}{ Intake (mg/kg-d) } & \multirow[b]{2}{*}{$\begin{array}{c}\mathrm{EPC}^{\mathrm{a}} \\
(\mu \mathrm{g} / \mathrm{L})\end{array}$} & \multicolumn{2}{|c|}{ Intake (mg/kg-d) } \\
\hline & & Ingestion & Dermal & & Ingestion & Dermal & & Ingestion & Dermal & & Ingestion & Dermal \\
\hline \multicolumn{13}{|c|}{ North of Slough (cont.) } \\
\hline MW-1002 & 330 & $9.2 \times 10^{-3}$ & $1.5 \times 10^{-5}$ & $\mathrm{NC}$ & - & - & 18 & $4.9 \times 10^{-4}$ & $7.8 \times 10^{-7}$ & $\mathrm{NC}$ & - & - \\
\hline MW-1004 & 340 & $9.3 \times 10^{-3}$ & $1.5 \times 10^{-5}$ & $\mathrm{NC}$ & - & - & 28 & $6.6 \times 10^{-4}$ & $1.1 \times 10^{-6}$ & 3.9 & $1.1 \times 10^{-4}$ & $1.7 \times 10^{-7}$ \\
\hline$M W-1005$ & NS & - & - & $\mathrm{NC}$ & - & - & NS & - & - & NS & - & - \\
\hline MW-1006 & 2,200 & $6.1 \times 10^{-2}$ & $9.7 \times 10^{-5}$ & $\mathrm{NC}$ & - & - & $\mathrm{NC}$ & - & - & 5.4 & $1.5 \times 10^{-4}$ & $2.4 \times 10^{-7}$ \\
\hline MW-1007 & 3,900 & $1.1 \times 10^{-1}$ & $1.7 \times 10^{-4}$ & $\mathrm{NC}$ & - & - & $\mathrm{NC}$ & - & - & 8.3 & $2.3 \times 10^{-4}$ & $3.6 \times 10^{-7}$ \\
\hline$M W-1008$ & 3,600 & $9.7 \times 10^{-2}$ & $1.6 \times 10^{-4}$ & $\mathrm{NC}$ & - & - & NC & - & - & $\mathrm{NC}$ & - & - \\
\hline MW- 1009 & 5,000 & $1.4 \times 10^{-1}$ & $2.2 \times 10^{-4}$ & $\mathrm{NC}$ & - & - & $\mathrm{NC}$ & - & - & 6.9 & $1.9 \times 10^{-4}$ & $3.0 \times 10^{-7}$ \\
\hline$M W-1013$ & 620 & $1.7 \times 10^{-2}$ & $2.7 \times 10^{-5}$ & $\mathrm{NC}$ & - & - & $\mathrm{NC}$ & - & - & NC & - & - \\
\hline$M W-1014$ & 170 & $4.7 \times 10^{-3}$ & $7.5 \times 10^{-6}$ & $\mathrm{NC}$ & - & - & $\mathrm{NC}$ & - & - & $\mathrm{NC}$ & _- & _- \\
\hline $\mathrm{MW}-1015$ & 98 & $2.7 \times 10^{-3}$ & $4.3 \times 10^{-6}$ & $\mathrm{NC}$ & - & - & $\mathrm{NC}$ & - & - & 3.3 & $9.0 \times 10^{-5}$ & $1.4 \times 10^{-7}$ \\
\hline$M W-1016$ & 220 & $6.0 \times 10^{-3}$ & $9.6 \times 10^{-6}$ & NC & - & - & $\mathrm{NC}$ & - & - & $\mathrm{NC}$ & - & - \\
\hline MW- 1026 & 2,000 & $5.3 \times 10^{-2}$ & $8.5 \times 10^{-5}$ & $\mathrm{NC}$ & - & - & 15 & $4.1 \times 10^{-4}$ & $6.6 \times 10^{-7}$ & $\mathrm{NC}$ & - & - \\
\hline$M W-1027$ & 55 & $1.5 \times 10^{-3}$ & $2.4 \times 10^{-6}$ & 0.16 & $4.4 \times 10^{-6}$ & $7.0 \times 10^{-9}$ & NC & - & - & $\mathrm{NC}$ & - & - \\
\hline MW-1028 & 810 & $2.2 \times 10^{-2}$ & $3.6 \times 10^{-5}$ & NC & - & - & NC & - & - & 5.5 & $1.5 \times 10^{-4}$ & $2.4 \times 10^{-7}$ \\
\hline$M W-1029$ & 95 & $2.6 \times 10^{-3}$ & $4.2 \times 10^{-6}$ & $\mathrm{NC}$ & - & - & 13 & $3.6 \times 10^{-4}$ & $5.7 \times 10^{-7}$ & 2.7 & $7.4 \times 10^{-5}$ & $1.2 \times 10^{-7}$ \\
\hline MW-1030 & 1,200 & $3.3 \times 10^{-2}$ & $5.2 \times 10^{-5}$ & $\mathrm{NC}$ & - & - & 61 & $1.7 \times 10^{-3}$ & $2.7 \times 10^{-6}$ & 4.7 & $1.3 \times 10^{-4}$ & $2.1 \times 10^{-7}$ \\
\hline$M W-103 i$ & 16 & $4.4 \times 10^{-4}$ & $7.0 \times 10^{-7}$ & $\mathrm{NC}$ & - & - & $\mathrm{NC}$ & - & - & 4.9 & $1.3 \times 10^{-4}$ & $2.1 \times 10^{-7}$ \\
\hline$M W-1032$ & 120 & $3.1 \times 10^{-3}$ & $5.0 \times 10^{-6}$ & $\mathrm{NC}$ & - & - & 18 & $4.9 \times 10^{-4}$ & $7.8 \times 10^{-7}$ & $\mathrm{NC}$ & - & - \\
\hline MW-1035 & 730 & $2.0 \times 10^{-2}$ & $3.2 \times 10^{-5}$ & 0.36 & $1.0 \times 10^{-5}$ & $1.6 \times 10^{-8}$ & $\mathrm{NC}$ & - & - & $\mathrm{NC}$ & - & - \\
\hline MW- 1036 & 640 & $1.8 \times 10^{-2}$ & $2.8 \times 10^{-5}$ & $\mathrm{NC}$ & - & - & 4.2 & $1.2 \times 10^{-4}$ & $1.8 \times 10^{-7}$ & NC & - & - \\
\hline$M W-1037$ & 1,700 & $4.7 \times 10^{-2}$ & $7.5 \times 10^{-5}$ & NC & - & - & $\mathrm{NC}$ & - & - & $\mathrm{NC}$ & - & - \\
\hline MW- 1038 & 410 & $1.1 \times 10^{-2}$ & $1.8 \times 10^{-5}$ & $\mathrm{NC}$ & - & - & $\mathrm{NC}$ & - & - & $\mathrm{NC}$ & - & - \\
\hline MW-1039 & 2,600 & $7.1 \times 10^{-2}$ & $1.1 \times 10^{-4}$ & $\mathrm{NC}$ & - & - & $\mathrm{NC}$ & - & - & $\mathrm{NC}$ & - & - \\
\hline$M W-1040$ & 1,300 & $3.5 \times 10^{-2}$ & $5.6 \times 10^{-5}$ & NC & - & - & 21 & $5.8 \times 10^{-4}$ & $9.2 \times 10^{-7}$ & 4.5 & $1.2 \times 10^{-4}$ & $2.0 \times 10^{-7}$ \\
\hline$M W-104 I$ & 1,100 & $2.9 \times 10^{-2}$ & $4.6 \times 10^{-5}$ & NC & - & - & 7.3 & $2.0 \times 10^{-4}$ & $3.2 \times 10^{-7}$ & $\mathrm{NC}$ & - & - \\
\hline$M W-1045$ & 1,300 & $3.5 \times 10^{-2}$ & $5.5 \times 10^{-5}$ & $\mathrm{NC}$ & - & - & 38 & $1.0 \times 10^{-3}$ & $1.6 \times 10^{-6}$ & $\mathrm{NC}$ & - & - \\
\hline MW-1046 & 190 & $5.3 \times 10^{-3}$ & $8.5 \times 10^{-6}$ & NC & - & - & 19 & $5.3 \times 10^{-4}$ & $8.4 \times 10^{-7}$ & $\mathrm{NC}$ & - & - \\
\hline MW-1047 & 470 & $1.3 \times 10^{-2}$ & $2.0 \times 10^{-5}$ & $\mathrm{NC}$ & - & - & 15 & $4.0 \times 10^{-4}$ & $6.4 \times 10^{-7}$ & $\mathrm{NC}$ & - & - \\
\hline MW-I048 & 570 & $1.6 \times 10^{-2}$ & $2.5 \times 10^{-5}$ & $\mathrm{NC}$ & - & - & $\mathrm{NC}$ & - & - & NC & - & - \\
\hline MW-1049 & 980 & $2.7 \times 10^{-2}$ & $4.3 \times 10^{-5}$ & NC & - & - & 13 & $3.6 \times 10^{-4}$ & $5.7 \times 10^{-7}$ & $\mathrm{NC}$ & - & - \\
\hline
\end{tabular}


TABLE 3.8 (Cont.)

\begin{tabular}{|c|c|c|c|c|c|c|c|c|c|}
\hline \multirow[b]{3}{*}{ Well ID } & \multicolumn{3}{|c|}{ Uranium } & \multicolumn{3}{|c|}{ Vanadium } & \multicolumn{3}{|c|}{ Zinc } \\
\hline & \multirow[b]{2}{*}{$\begin{array}{l}\mathrm{EPC}^{\mathrm{a}} \\
(\mu \mathrm{g} / \mathrm{L})\end{array}$} & \multicolumn{2}{|c|}{ Intake $(m g / k g-d)$} & \multirow[b]{2}{*}{$\begin{array}{l}\mathrm{EPC}^{\mathrm{a}} \\
(\mu \mathrm{g} / \mathrm{L})\end{array}$} & \multicolumn{2}{|c|}{ Intake (mg/kg-d) } & \multirow[b]{2}{*}{$\begin{array}{l}\mathrm{EPC}^{\mathrm{a}} \\
(\mu \mathrm{g} / \mathrm{L})\end{array}$} & \multicolumn{2}{|c|}{ Intake $(\mathrm{mg} / \mathrm{kg}-\mathrm{d})$} \\
\hline & & Ingestion & Dermal & & Ingestion & Dermal & & Ingestion & Dermal \\
\hline \multicolumn{10}{|c|}{ North of Slough (cont.) } \\
\hline$M W-1002$ & 5.4 & $1.5 \times 10^{-4}$ & $2.4 \times 10^{-7}$ & $\mathrm{NC}$ & - & - & 8.4 & $2.3 \times 10^{-4}$ & $3.7 \times 10^{-7}$ \\
\hline MW-1004 & 5,300 & $1.4 \times 10^{-1}$ & $2.3 \times 10^{-4}$ & $\mathrm{NC}$ & - & - & 14 & $3.8 \times 10^{-4}$ & $6.0 \times 10^{-7}$ \\
\hline MW-1005 & 3,300 & $9.0 \times 10^{-2}$ & $1.4 \times 10^{-4}$ & NS & - & - & NS & - & - \\
\hline MW-1006 & 4,600 & $1.3 \times 10^{-1}$ & $2.0 \times 10^{-4}$ & 25 & $6.8 \times 10^{-4}$ & $1.1 \times 10^{-6}$ & 21 & $5.8 \times 10^{-4}$ & $9.3 \times 10^{-7}$ \\
\hline MW-1007 & 91 & $2.5 \times 10^{-3}$ & $4.0 \times 10^{-6}$ & 28 & $7.6 \times 10^{-4}$ & $1.2 \times 10^{-6}$ & 23 & $6.4 \times 10^{-4}$ & $1.0 \times 10^{-6}$ \\
\hline$M W-1008$ & 5,200 & $1.4 \times 10^{-1}$ & $2.3 \times 10^{-4}$ & 34 & $9.2 \times 10^{-4}$ & $1.5 \times 10^{-6}$ & 30 & $8.3 \times 10^{-4}$ & $1.3 \times 10^{-6}$ \\
\hline MW-1009 & 23 & $6.2 \times 10^{-4}$ & $9.9 \times 10^{-7}$ & 18 & $5.0 \times 10^{-4}$ & $8.1 \times 10^{-7}$ & 22 & $6.0 \times 10^{-4}$ & $9.6 \times 10^{-7}$ \\
\hline$M W-1013$ & 1,400 & $3.7 \times 10^{-2}$ & $6.0 \times 10^{-5}$ & $\mathrm{NC}$ & - & - & 15 & $4.1 \times 10^{-4}$ & $6.5 \times 10^{-7}$ \\
\hline$M W-1014$ & 1,700 & $4.6 \times 10^{-2}$ & $7.4 \times 10^{-5}$ & $\mathrm{NC}$ & - & - & 9.8 & $2.7 \times 10^{-4}$ & $4.3 \times 10^{-7}$ \\
\hline MW-1015 & 500 & $1.4 \times 10^{-2}$ & $2.2 \times 10^{-5}$ & 14 & $3.7 \times 10^{-4}$ & $5.9 \times 10^{-7}$ & 67 & $1.8 \times 10^{-3}$ & $2.9 \times 10^{-6}$ \\
\hline MW-1016 & 310 & $8.4 \times 10^{-3}$ & $1.3 \times 10^{-5}$ & 16 & $4.4 \times 10^{-4}$ & $7.0 \times 10^{-7}$ & 69 & $1.9 \times 10^{-3}$ & $3.0 \times 10^{-6}$ \\
\hline$M W-1026$ & 0.15 & $4.1 \times 10^{-6}$ & $6.6 \times 10^{-9}$ & 14 & $3.7 \times 10^{-4}$ & $6.0 \times 10^{-7}$ & 12 & $3.4 \times 10^{-4}$ & $5.4 \times 10^{-7}$ \\
\hline$M W-1027$ & 640 & $1.8 \times 10^{-2}$ & $2.8 \times 10^{-5}$ & 15 & $4.0 \times 10^{-4}$ & $6.4 \times 10^{-7}$ & 72 & $2.0 \times 10^{-3}$ & $3.2 \times 10^{-6}$ \\
\hline$M W-1028$ & 4.6 & $1.3 \times 10^{-4}$ & $2.0 \times 10^{-7}$ & NC & - & - & 10 & $2.7 \times 10^{-4}$ & $4.4 \times 10^{-7}$ \\
\hline$M W-1029$ & 3.2 & $8.8 \times 10^{-5}$ & $1.4 \times 10^{-7}$ & 12 & $3.4 \times 10^{-4}$ & $5.4 \times 10^{-7}$ & 24 & $6.6 \times 10^{-4}$ & $1.1 \times 10^{-6}$ \\
\hline$M W-1030$ & 95 & $2.6 \times 10^{-3}$ & $4.2 \times 10^{-6}$ & 17 & $4.5 \times 10^{-4}$ & $7.2 \times 10^{-7}$ & 120 & $3.2 \times 10^{-3}$ & $5.2 \times 10^{-6}$ \\
\hline MW-1031 & 260 & $7.0 \times 10^{-3}$ & $1.1 \times 10^{-5}$ & $\mathrm{NC}$ & - & - & 6.7 & $1.8 \times 10^{-4}$ & $2.9 \times 10^{-7}$ \\
\hline$M W-1032$ & 1,600 & $4.3 \times 10^{-2}$ & $6.9 \times 10^{-5}$ & $\mathrm{NC}$ & - & - & 24 & $6.6 \times 10^{-4}$ & $1.1 \times 10^{-6}$ \\
\hline MW-1035 & 0.83 & $2.3 \times 10^{-5}$ & $3.6 \times 10^{-8}$ & 2.7 & $7.4 \times 10^{-5}$ & $1.2 \times 10^{-7}$ & 9.2 & $2.5 \times 10^{-4}$ & $4.0 \times 10^{-7}$ \\
\hline MW-1036 & 12 & $3.2 \times 10^{-4}$ & $5.2 \times 10^{-7}$ & 3.6 & $9.9 \times 10^{-5}$ & $1.6 \times 10^{-7}$ & 15 & $4.2 \times 10^{-4}$ & $6.7 \times 10^{-7}$ \\
\hline$M W-1037$ & 3.1 & $8.5 \times 10^{-5}$ & $1.4 \times 10^{-7}$ & 7.0 & $1.9 \times 10^{-4}$ & $3.1 \times 10^{-7}$ & 36 & $9.9 \times 10^{-4}$ & $1.6 \times 10^{-6}$ \\
\hline$M W-1038$ & 5.8 & $1.6 \times 10^{-4}$ & $2.5 \times 10^{-7}$ & 8.4 & $2.3 \times 10^{-4}$ & $3.7 \times 10^{-7}$ & 42 & $1.1 \times 10^{-3}$ & $1.8 \times 10^{-6}$ \\
\hline MW-1039 & 0.92 & $2.5 \times 10^{-5}$ & $4.0 \times 10^{-8}$ & 3.0 & $8.2 \times 10^{-5}$ & $1.3 \times 10^{-7}$ & 38 & $1.0 \times 10^{-3}$ & $1.7 \times 10^{-6}$ \\
\hline $\mathrm{MW}-1040$ & 10 & $2.7 \times 10^{-4}$ & $4.4 \times 10^{-7}$ & 32 & $8.8 \times 10^{-4}$ & $1.4 \times 10^{-6}$ & 85 & $2.3 \times 10^{-3}$ & $3.7 \times 10^{-6}$ \\
\hline MW-1041 & 6.7 & $1.8 \times 10^{-4}$ & $2.9 \times 10^{-7}$ & $\mathrm{NC}$ & - & - & 18 & $4.9 \times 10^{-4}$ & $7.9 \times 10^{-7}$ \\
\hline MW-1045 & 8.7 & $2.4 \times 10^{-4}$ & $3.8 \times 10^{-7}$ & 40 & $1.1 \times 10^{-3}$ & $1.8 \times 10^{-6}$ & 54 & $1.5 \times 10^{-3}$ & $2.4 \times 10^{-6}$ \\
\hline$M W-1046$ & 42 & $1.2 \times 10^{-3}$ & $1.8 \times 10^{-6}$ & 19 & $5.1 \times 10^{-4}$ & $8.1 \times 10^{-7}$ & 60 & $1.6 \times 10^{-3}$ & $2.6 \times 10^{-6}$ \\
\hline MW-1047 & 5.3 & $1.2 \times 10^{-4}$ & $2.0 \times 10^{-7}$ & 19 & $5.1 \times 10^{-4}$ & $8.2 \times 10^{-7}$ & 97 & $2.7 \times 10^{-3}$ & $4.2 \times 10^{-6}$ \\
\hline$M W-1048$ & 300 & $8.2 \times 10^{-3}$ & $1.3 \times 10^{-5}$ & 67 & $1.8 \times 10^{-3}$ & $2.9 \times 10^{-6}$ & 160 & $4.5 \times 10^{-3}$ & $7.2 \times 10^{-6}$ \\
\hline$M W-1049$ & 0.74 & $2.0 \times 10^{-5}$ & $3.2 \times 10^{-8}$ & 13 & $3.7 \times 10^{-4}$ & $5.9 \times 10^{-7}$ & 46 & $1.3 \times 10^{-3}$ & $2.0 \times 10^{-6}$ \\
\hline
\end{tabular}


TABLE 3.8 (Cont.)

\begin{tabular}{|c|c|c|c|c|c|c|c|c|c|c|c|c|}
\hline \multirow[b]{3}{*}{ Well ID } & \multicolumn{3}{|c|}{ Barium } & \multicolumn{3}{|c|}{ Cadmium } & \multicolumn{3}{|c|}{ Chromium } & \multicolumn{3}{|c|}{ Copper } \\
\hline & \multirow[b]{2}{*}{$\begin{array}{c}\mathrm{EPC}^{\mathrm{a}} \\
(\mu \mathrm{g} / \mathrm{L})\end{array}$} & \multicolumn{2}{|c|}{ Intake (mg/kg-d) } & \multirow[b]{2}{*}{$\begin{array}{c}\mathrm{EPC}^{\mathrm{a}} \\
(\mu \mathrm{g} / \mathrm{L})\end{array}$} & \multicolumn{2}{|c|}{ Intake $(\mathrm{mg} / \mathrm{kg}-\mathrm{d})$} & \multirow[b]{2}{*}{$\begin{array}{c}\mathrm{EPC}^{\mathrm{t}} \\
(\mu \mathrm{g} / \mathrm{L})\end{array}$} & \multicolumn{2}{|c|}{ Intake $(\mathrm{mg} / \mathrm{kg}-\mathrm{d})$} & \multirow[b]{2}{*}{$\begin{array}{c}\mathrm{EPC}^{\mathrm{a}} \\
(\mu \mathrm{g} / \mathrm{L})\end{array}$} & \multicolumn{2}{|c|}{ Intake $(\mathrm{mg} / \mathrm{kg}-\mathrm{d})$} \\
\hline & & Ingestion & Dermal & & Ingestion & Dermal & & Ingestion & Dermal & & Ingestion & Dermal \\
\hline \multicolumn{13}{|c|}{ South of Slough } \\
\hline MW-1010 & 340 & $9.4 \times 10^{-3}$ & $1.5 \times 10^{-5}$ & $\mathrm{NC}$ & - & - & $\mathrm{NC}$ & - & - & 14 & $3.8 \times 10^{-4}$ & $6.0 \times 10^{-7}$ \\
\hline MW-1011 & 100 & $2.8 \times 10^{-3}$ & $4.4 \times 10^{-6}$ & $\mathrm{NC}$ & - & - & $\mathrm{NC}$ & - & - & 39 & $1.1 \times 10^{-3}$ & $1.7 \times 10^{-6}$ \\
\hline MW-1017 & 890 & $2.4 \times 10^{-2}$ & $3.9 \times 10^{-5}$ & NC & - & - & 8.8 & $2.4 \times 10^{-4}$ & $3.8 \times 10^{-7}$ & 13 & $3.7 \times 10^{-4}$ & $5.9 \times 10^{-7}$ \\
\hline MW-1018 & 530 & $1.4 \times 10^{-2}$ & $2.3 \times 10^{-5}$ & NC & - & - & 6.4 & $1.8 \times 10^{-4}$ & $2.8 \times 10^{-7}$ & 8.4 & $2.3 \times 10^{-4}$ & $3.7 \times 10^{-7}$ \\
\hline MW-1019 & 670 & $1.8 \times 10^{-2}$ & $2.9 \times 10^{-5}$ & $\mathrm{NC}$ & - & - & 6.7 & $1.8 \times 10^{-4}$ & $2.9 \times 10^{-7}$ & 9.2 & $2.5 \times 10^{-4}$ & $4.0 \times 10^{-7}$ \\
\hline MW- 1020 & 350 & $9.7 \times 10^{-3}$ & $1.6 \times 10^{-5}$ & $\mathrm{NC}$ & - & - & $\mathrm{NC}$ & - & - & 14 & $3.9 \times 10^{-4}$ & $6.3 \times 10^{-7}$ \\
\hline MW-1021 & 700 & $1.9 \times 10^{-2}$ & $3.1 \times 10^{-5}$ & NC & - & - & 3.8 & $1.0 \times 10^{-4}$ & $1.7 \times 10^{-7}$ & 8.9 & $2.4 \times 10^{-4}$ & $3.9 \times 10^{-7}$ \\
\hline$M W-1022$ & 490 & $1.3 \times 10^{-2}$ & $2.1 \times 10^{-5}$ & $\mathrm{NC}$ & _ & - & $\mathrm{NC}$ & - & - & 5.4 & $1.5 \times 10^{-4}$ & $2.4 \times 10^{-7}$ \\
\hline $\mathrm{MW}-1023$ & 600 & $1.6 \times 10^{-2}$ & $2.6 \times 10^{-5}$ & $\mathrm{NC}$ & - & - & 18 & $4.9 \times 10^{-4}$ & $7.8 \times 10^{-7}$ & 28 & $7.6 \times 10^{-4}$ & $1.2 \times 10^{-6}$ \\
\hline$M W-1033$ & 760 & $2.1 \times 10^{-2}$ & $3.3 \times 10^{-5}$ & $\mathrm{NC}$ & - & $\ldots$ & 5.1 & $1.4 \times 10^{-4}$ & $2.2 \times 10^{-7}$ & 4.3 & $1.2 \times 10^{-4}$ & $1.9 \times 10^{-7}$ \\
\hline MW-1044 & 620 & $1.7 \times 10^{-2}$ & $2.7 \times 10^{-5}$ & $\mathrm{NC}$ & - & - & 11 & $3.0 \times 10^{-4}$ & $4.8 \times 10^{-7}$ & 34 & $9.4 \times 10^{-4}$ & $1.5 \times 10^{-6}$ \\
\hline RMW-1 & 620 & $1.7 \times 10^{-2}$ & $2.7 \times 10^{-5}$ & $\mathrm{NC}$ & - & - & 9.9 & $2.7 \times 10^{-4}$ & $4.3 \times 10^{-7}$ & 2.6 & $7.1 \times 10^{-5}$ & $1.1 \times 10^{-7}$ \\
\hline RMW-2 & 390 & $1.1 \times 10^{-2}$ & $1.7 \times 10^{-5}$ & $\mathrm{NC}$ & - & - & 8.1 & $2.2 \times 10^{-4}$ & $3.6 \times 10^{-7}$ & $\mathrm{NC}$ & - & - \\
\hline RMW-3 & 450 & $1.2 \times 10^{-2}$ & $2.0 \times 10^{-5}$ & NC & - & - & $\mathrm{NC}$ & - & - & $\mathrm{NC}$ & - & - \\
\hline RMW-4 & 260 & $7.0 \times 10^{-3}$ & $1.1 \times 10^{-5}$ & $\mathrm{NC}$ & - & - & NC & - & - & $\mathrm{NC}$ & - & - \\
\hline
\end{tabular}


TABLE 3.8 (Cont.)

\begin{tabular}{|c|c|c|c|c|c|c|c|c|c|c|c|c|}
\hline \multirow[b]{3}{*}{ Well ID } & \multicolumn{3}{|c|}{ Manganese } & \multicolumn{3}{|c|}{ Mercury } & \multicolumn{3}{|c|}{ Nickel } & \multicolumn{3}{|c|}{ Thallium } \\
\hline & \multirow[b]{2}{*}{$\begin{array}{c}\mathrm{EPC}^{\mathrm{a}} \\
(\mu \mathrm{g} / \mathrm{L})\end{array}$} & \multicolumn{2}{|c|}{ Intake (mg/kg-d) } & \multirow[b]{2}{*}{$\begin{array}{c}E P C^{\mathrm{a}} \\
(\mu \mathrm{g} / \mathrm{L})\end{array}$} & \multicolumn{2}{|c|}{ Intake (mg/kg-d) } & \multirow{2}{*}{$\begin{array}{c}\mathrm{EPC}^{\mathrm{al}} \\
(\mu \mathrm{g} / \mathrm{L})\end{array}$} & \multicolumn{2}{|c|}{ Intake (mg/kg-d) } & \multirow[b]{2}{*}{$\begin{array}{c}\mathrm{EPC}^{\mathrm{a}} \\
(\mu \mathrm{g} / \mathrm{L})\end{array}$} & \multicolumn{2}{|c|}{ Intake (mg/kg-d) } \\
\hline & & Ingestion & Dermal & & Ingestion & Dermal & & Ingestion & Dermal & & Ingestion & Dermal \\
\hline \multicolumn{13}{|c|}{ South of Slough (cont.) } \\
\hline$M W-1010$ & 1,000 & $2.8 \times 10^{-2}$ & $4.6 \times 10^{-5}$ & $\mathrm{NC}$ & - & - & $\mathrm{NC}$ & - & - & $\mathrm{NC}$ & - & - \\
\hline$M W-1011$ & 24 & $6.7 \times 10^{-4}$ & $1.1 \times 10^{-6}$ & $\mathrm{NC}$ & - & - & NC & - & - & $\mathrm{NC}$ & - & - \\
\hline$M W-1017$ & 390 & $1.1 \times 10^{-2}$ & $1.7 \times 10^{-5}$ & $\mathrm{NC}$ & - & - & 14 & $3.9 \times 10^{-4}$ & $6.3 \times 10^{-7}$ & 4.5 & $1.2 \times 10^{-4}$ & $2.0 \times 10^{-7}$ \\
\hline MW-1018 & 790 & $2.2 \times 10^{-2}$ & $3.5 \times 10^{-5}$ & $\mathrm{NC}$ & - & - & 21 & $5.8 \times 10^{-4}$ & $9.3 \times 10^{-7}$ & 4.9 & $1.3 \times 10^{-4}$ & $2.1 \times 10^{-7}$ \\
\hline MW-1019 & 1,900 & $5.2 \times 10^{-2}$ & $8.3 \times 10^{-5}$ & $\mathrm{NC}$ & - & - & $\mathrm{NC}$ & - & - & $\mathrm{NC}$ & - & - \\
\hline MW-1020 & 2,400 & $6.5 \times 10^{-2}$ & $1.0 \times 10^{-4}$ & $\mathrm{NC}$ & - & - & 11 & $3.0 \times 10^{-4}$ & $4.8 \times 10^{-7}$ & 3.5 & $9.6 \times 10^{-5}$ & $1.5 \times 10^{-7}$ \\
\hline$M W-1021$ & 510 & $1.4 \times 10^{-2}$ & $2.2 \times 10^{-5}$ & $\mathrm{NC}$ & - & - & 12 & $3.3 \times 10^{-4}$ & $5.3 \times 10^{-7}$ & 3.1 & $8.5 \times 10^{-5}$ & $1.4 \times 10^{-7}$ \\
\hline MW-1022 & 580 & $1.6 \times 10^{-2}$ & $2.5 \times 10^{-5}$ & $\mathrm{NC}$ & - & - & 14 & $3.8 \times 10^{-4}$ & $6.1 \times 10^{-7}$ & $\mathrm{NC}$ & - & - \\
\hline$M W-1023$ & 760 & $2.1 \times 10^{-2}$ & $3.3 \times 10^{-5}$ & NC & - & - & 27 & $7.5 \times 10^{-4}$ & $1.2 \times 10^{-6}$ & 4.1 & $1.1 \times 10^{-4}$ & $1.8 \times 10^{-7}$ \\
\hline MW-1033 & 1,300 & $3.5 \times 10^{-2}$ & $5.5 \times 10^{-5}$ & $\mathrm{NC}$ & - & - & 13 & $3.5 \times 10^{-4}$ & $5.6 \times 10^{-7}$ & $\mathrm{NC}$ & - & - \\
\hline$M W-1044$ & 920 & $2.5 \times 10^{-2}$ & $4.0 \times 10^{-5}$ & NC & - & - & 9.8 & $2.7 \times 10^{-4}$ & $4.3 \times 10^{-7}$ & NC & - & - \\
\hline RMW-I & 2,900 & $8.0 \times 10^{-2}$ & $1.3 \times 10^{-4}$ & $\mathrm{NC}$ & - & - & 8.8 & $2.4 \times 10^{-4}$ & $3.9 \times 10^{-7}$ & $\mathrm{NC}$ & - & - \\
\hline RMW-2 & 860 & $2.3 \times 10^{-2}$ & $3.7 \times 10^{-5}$ & $\mathrm{NC}$ & - & - & NC & - & - & $\mathrm{NC}$ & - & - \\
\hline RMW-3 & NS & - & - & NS & - & - & NS & - & - & NS & - & - \\
\hline RMW-4 & NS & - & - & NS & - & - & NS & - & - & NS & - & - \\
\hline
\end{tabular}


TABLE 3.8 (Cont.)

\begin{tabular}{|c|c|c|c|c|c|c|c|c|c|}
\hline \multirow[b]{3}{*}{ Well ID } & \multicolumn{3}{|c|}{ Uranium } & \multicolumn{3}{|c|}{ Vanadium } & \multicolumn{3}{|c|}{ Zinc } \\
\hline & \multirow[b]{2}{*}{$\begin{array}{c}\mathrm{EPC}^{\mathrm{a}} \\
(\mu \mathrm{g} / \mathrm{L})\end{array}$} & \multicolumn{2}{|c|}{ Intake (mg/kg-d) } & \multirow[b]{2}{*}{$\begin{array}{c}\mathrm{EPC}^{\mathrm{at}} \\
(\mu \mathrm{L} / \mathrm{L})\end{array}$} & \multicolumn{2}{|c|}{ Intake (mg/kg-d) } & \multirow[b]{2}{*}{$\begin{array}{c}\mathrm{EPC}^{\mathrm{a}} \\
(\mu \mathrm{g} / \mathrm{L})\end{array}$} & \multicolumn{2}{|c|}{ Intake (mg/kg-d) } \\
\hline & & Ingestion & Dermal & & Ingestion & Dermal & & Ingestion & Dermal \\
\hline \multicolumn{10}{|c|}{ South of Slough (cont.) } \\
\hline$M W-1010$ & 0.66 & $1.8 \times 10^{-5}$ & $2.9 \times 10^{-8}$ & 7.6 & $2.1 \times 10^{-4}$ & $3.3 \times 10^{-7}$ & 8.2 & $2.2 \times 10^{-4}$ & $3.6 \times 10^{-7}$ \\
\hline$M W-1011$ & 8.3 & $2.3 \times 10^{-4}$ & $3.6 \times 10^{-7}$ & 12 & $3.3 \times 10^{-4}$ & $5.2 \times 10^{-7}$ & $\mathrm{NC}$ & - & - \\
\hline$M W-1017$ & 2.2 & $6.0 \times 10^{-5}$ & $9.6 \times 10^{-8}$ & 13 & $3.7 \times 10^{-4}$ & $5.9 \times 10^{-7}$ & 67 & $1.8 \times 10^{-3}$ & $2.9 \times 10^{-6}$ \\
\hline MW-1018 & 2.7 & $7.4 \times 10^{-5}$ & $1.2 \times 10^{-7}$ & 9.8 & $2.7 \times 10^{-4}$ & $4.3 \times 10^{-7}$ & 47 & $1.3 \times 10^{-3}$ & $2.1 \times 10^{-6}$ \\
\hline MW-1019 & 7.6 & $2.1 \times 10^{-4}$ & $3.3 \times 10^{-7}$ & 9.1 & $2.5 \times 10^{-4}$ & $4.0 \times 10^{-7}$ & 43 & $1.2 \times 10^{-3}$ & $1.9 \times 10^{-6}$ \\
\hline $\mathrm{MW}-1020$ & 6.7 & $1.8 \times 10^{-4}$ & $2.9 \times 10^{-7}$ & 14 & $3.7 \times 10^{-4}$ & $5.9 \times 10^{-7}$ & 11 & $3.1 \times 10^{-4}$ & $5.0 \times 10^{-7}$ \\
\hline$M W-1021$ & 1.3 & $3.6 \times 10^{-5}$ & $5.7 \times 10^{-8}$ & 7.9 & $2.2 \times 10^{-4}$ & $3.5 \times 10^{-7}$ & 37 & $1.0 \times 10^{-3}$ & $1.6 \times 10^{-6}$ \\
\hline$M W-1022$ & 1.3 & $3.6 \times 10^{-5}$ & $5.7 \times 10^{-8}$ & 3.7 & $1.0 \times 10^{-4}$ & $1.6 \times 10^{-7}$ & 31 & $8.5 \times 10^{-4}$ & $1.4 \times 10^{-6}$ \\
\hline$M W-1023$ & 2.7 & $7.4 \times 10^{-5}$ & $1.2 \times 10^{-7}$ & 31 & $8.6 \times 10^{-4}$ & $1.4 \times 10^{-6}$ & 110 & $3.0 \times 10^{-3}$ & $4.9 \times 10^{-6}$ \\
\hline$M W-1033$ & 5.6 & $1.5 \times 10^{-4}$ & $2.4 \times 10^{-7}$ & $\mathrm{NC}$ & - & - & 14 & $3.8 \times 10^{-4}$ & $6.0 \times 10^{-7}$ \\
\hline$M W-1044$ & 0.46 & $1.3 \times 10^{-5}$ & $2.0 \times 10^{-8}$ & 24 & $6.7 \times 10^{-4}$ & $1.1 \times 10^{-6}$ & 63 & $1.7 \times 10^{-3}$ & $2.8 \times 10^{-6}$ \\
\hline RMW-1 & 2.3 & $6.3 \times 10^{-5}$ & $1.0 \times 10^{-7}$ & $\mathrm{NC}$ & - & - & 36 & $9.8 \times 10^{-4}$ & $1.6 \times 10^{-6}$ \\
\hline RMW-2 & 10 & $2.8 \times 10^{-4}$ & $4.5 \times 10^{-7}$ & $\mathrm{NC}$ & - & - & 33 & $9.2 \times 10^{-4}$ & $1.5 \times 10^{-6}$ \\
\hline RMW-3 & 1.6 & $4.4 \times 10^{-5}$ & $7.0 \times 10^{-8}$ & NS & - & - & NS & - & - \\
\hline RMW-4 & 3.8 & $1.0 \times 10^{-4}$ & $1.7 \times 10^{-7}$ & NS & - & - & NS & - & - \\
\hline
\end{tabular}

a Exposure point concentration $(E P C)=$ upper confidence limit (UCL) or the maximum value reported for each well from the data collecied since 1995 .

b $\mathrm{NC}=$ not calculated because parameter not detected in this well; NS = sample not analyzed for this parameter

c A hyphen (-) indicates that parameter was not detected. 
TABLE 3.9 Estimated Noncarcinogenic Intakes of Nitroaromatic Compound COPCs for a Hypothetical Future Resident ${ }^{\mathrm{a}}$

\begin{tabular}{|c|c|c|c|c|c|c|c|c|c|}
\hline \multirow[b]{3}{*}{ Well ID } & \multicolumn{3}{|c|}{ 1,3,5-TNB } & \multicolumn{3}{|c|}{ 1,3-DNB } & \multicolumn{3}{|c|}{$2,4,6-\mathrm{TNT}$} \\
\hline & \multirow[b]{2}{*}{$\begin{array}{c}\text { EPC }^{h} \\
(\mu \mathrm{g} / \mathrm{L})\end{array}$} & \multicolumn{2}{|c|}{ Intake $(\mathrm{mg} / \mathrm{kg}-\mathrm{d})$} & \multirow[b]{2}{*}{$\begin{array}{l}\mathrm{EPC}^{\mathrm{h}} \\
(\mu \mathrm{g} / \mathrm{L})\end{array}$} & \multicolumn{2}{|c|}{ Intake (mg/kg-d) } & \multirow[b]{2}{*}{$\begin{array}{l}\mathrm{EPC}^{\mathrm{b}} \\
(\mu \mathrm{g} / \mathrm{L})\end{array}$} & \multicolumn{2}{|c|}{ Intake $(\mathrm{mg} / \mathrm{kg}-\mathrm{d})$} \\
\hline & & Ingestion & Dermal & & Ingestion & Dermal & & Ingestion & Dermal \\
\hline MW-1002 & 160 & $4.4 \times 10^{-3}$ & $7.0 \times 10^{-6}$ & 0.42 & $1.2 \times 10^{-5}$ & $1.8 \times 10^{-8}$ & 34 & $9.3 \times 10^{-4}$ & $1.5 \times 10^{-6}$ \\
\hline MW-1004 & 1.1 & $3.0 \times 10^{-5}$ & $4.9 \times 10^{-8}$ & 0.60 & $1.7 \times 10^{-5}$ & $2.6 \times 10^{-8}$ & 9.9 & $2.7 \times 10^{-4}$ & $4.3 \times 10^{-7}$ \\
\hline MW-1005 & $\mathrm{NC}^{\mathfrak{c}}$ & $-{ }^{d}$ & - & $\mathrm{NC}$ & - & - & $\mathrm{NC}$ & - & - \\
\hline MW-1006 & 120 & $3.4 \times 10^{-3}$ & $5.4 \times 10^{-6}$ & 0.14 & $3.8 \times 10^{-6}$ & $6.1 \times 10^{-9}$ & 12 & $3.2 \times 10^{-4}$ & $5.1 \times 10^{-7}$ \\
\hline MW- 1007 & 0.27 & $7.4 \times 10^{-6}$ & $1.2 \times 10^{-8}$ & $\mathrm{NC}$ & - & - & 0.078 & $2.1 \times 10^{-6}$ & $3.4 \times 10^{-4}$ \\
\hline MW-1008 & 0.12 & $3.2 \times 10^{-6}$ & $5.0 \times 10^{-9}$ & $\mathrm{NC}$ & - & - & 0.19 & $5.3 \times 10^{-6}$ & $8.5 \times 10^{-9}$ \\
\hline MW-1009 & $\mathrm{NC}$ & - & - & $\mathrm{NC}$ & - & - & $\mathrm{NC}$ & - & - \\
\hline MW-1013 & $\mathrm{NC}$ & - & - & $\mathrm{NC}$ & - & - & $\mathrm{NC}$ & - & - \\
\hline MW-1014 & $\mathrm{NC}$ & - & - & $\mathrm{NC}$ & - & - & $\mathrm{NC}$ & - & - \\
\hline MW-1015 & 7.4 & $2.0 \times 10^{-4}$ & $3.3 \times 10^{-7}$ & 0.16 & $4.3 \times 10^{-6}$ & $6.9 \times 10^{-9}$ & 2.9 & $7.9 \times 10^{-5}$ & $1.3 \times 10^{-7}$ \\
\hline MW-1016 & 0.50 & $1.4 \times 10^{-5}$ & $2.2 \times 10^{-8}$ & $\mathrm{NC}$ & - & - & 0.30 & $8.3 \times 10^{-6}$ & $1.3 \times 10^{-8}$ \\
\hline MW-1026 & $\mathrm{NC}$ & - & - & $\mathrm{NC}$ & - & - & $\mathrm{NC}$ & - & - \\
\hline MW-1027 & 0.051 & $1.4 \times 10^{-6}$ & $2.2 \times 10^{-9}$ & $\mathrm{NC}$ & - & - & 1.1 & $3.1 \times 10^{-5}$ & $4.9 \times 10^{-8}$ \\
\hline MW-1028 & $\mathrm{NC}$ & - & - & $\mathrm{NC}$ & - & - & $\mathrm{NC}$ & - & - \\
\hline MW-1029 & NC & - & - & $\mathrm{NC}$ & - & - & $\mathrm{NC}$ & - & - \\
\hline$M W-1030$ & $\mathrm{NC}$ & - & - & $\mathrm{NC}$ & - & - & 0.022 & $6.0 \times 10^{-7}$ & $9.5 \times 10^{-10}$ \\
\hline$M W-1031$ & $\mathrm{NC}$ & - & - & $\mathrm{NC}$ & - & - & $\mathrm{NC}$ & - & - \\
\hline$M W-1032$ & 0.13 & $3.5 \times 10^{-6}$ & $5.5 \times 10^{-9}$ & $\mathrm{NC}$ & - & - & 0.43 & $1.2 \times 10^{-5}$ & $1.9 \times 10^{-8}$ \\
\hline MW-1035 & $\mathrm{NC}$ & - & - & $\mathrm{NC}$ & - & - & $\mathrm{NC}$ & - & - \\
\hline MW-1036 & $\mathrm{NC}$ & - & - & $\mathrm{NC}$ & - & - & $\mathrm{NC}$ & - & - \\
\hline MW-1037 & $\mathrm{NC}$ & - & - & $\mathrm{NC}$ & - & - & $\mathrm{NC}$ & - & - \\
\hline$M W-1038$ & NC & - & - & NC & - & - & $\mathrm{NC}$ & - & - \\
\hline$M W-1039$ & $\mathrm{NC}$ & - & - & $\mathrm{NC}$ & - & - & $\mathrm{NC}$ & - & - \\
\hline MW- 1040 & $\mathrm{NC}$ & - & - & $\mathrm{NC}$ & - & - & $\mathrm{NC}$ & - & - \\
\hline MW-1041 & $\mathrm{NC}$ & - & - & $\mathrm{NC}$ & - & - & $\mathrm{NC}$ & - & - \\
\hline$M W-1045$ & $\mathrm{NC}$ & - & - & NC & - & - & $\mathrm{NC}$ & - & - \\
\hline MW-1046 & $\mathrm{NC}$ & - & - & $\mathrm{NC}$ & - & - & $\mathrm{NC}$ & - & - \\
\hline MW-1047 & $\mathrm{NC}$ & - & - & NC & - & - & $\mathrm{NC}$ & - & - \\
\hline MW-1048 & $\mathrm{NC}$ & - & - & NC & - & - & NC & - & - \\
\hline MW-1049 & $\mathrm{NC}$ & - & - & $\mathrm{NC}$ & - & - & $\mathrm{NC}$ & - & - \\
\hline
\end{tabular}


TABLE 3.9 (Cont.)

\begin{tabular}{|c|c|c|c|c|c|c|}
\hline \multirow[b]{3}{*}{ Well ID } & \multicolumn{3}{|c|}{ 2,4-DNT } & \multicolumn{3}{|c|}{ 2,6-DNT } \\
\hline & \multirow[b]{2}{*}{$\begin{array}{r}\mathrm{EPC}^{\mathrm{b}} \\
(\mu \mathrm{g} / \mathrm{L}) \\
\end{array}$} & \multicolumn{2}{|c|}{ Intake (mg/kg-d) } & \multirow[b]{2}{*}{$\begin{array}{c}\mathrm{EPC}^{\mathrm{h}} \\
(\mu \mathrm{g} / \mathrm{L}) \\
\end{array}$} & \multicolumn{2}{|c|}{ Intake $(\mathrm{mg} / \mathrm{kg}-\mathrm{d})$} \\
\hline & & Ingestion & Dermal & & Ingestion & Dermal \\
\hline MW-1002 & 0.13 & $3.6 \times 10^{-6}$ & $5.8 \times 10^{-4}$ & 12 & $3.3 \times 10^{-4}$ & $5.2 \times 10^{-7}$ \\
\hline MW-1004 & 0.71 & $1.9 \times 10^{-5}$ & $3.1 \times 10^{-8}$ & 0.94 & $2.6 \times 10^{-5}$ & $4.1 \times 10^{-8}$ \\
\hline MW-1005 & $\mathrm{NC}$ & - & - & $\mathrm{NC}$ & - & - \\
\hline MW-1006 & 0.45 & $1.2 \times 10^{-5}$ & $2.0 \times 10^{-8}$ & 2.3 & $6.4 \times 10^{-5}$ & $1.0 \times 10^{-7}$ \\
\hline MW-1007 & $\mathrm{NC}$ & - & - & 0.024 & $6.5 \times 10^{-7}$ & $1.0 \times 10^{-9}$ \\
\hline MW-1008 & $\mathrm{NC}$ & - & - & 0.043 & $1.2 \times 10^{-6}$ & $1.9 \times 10^{-9}$ \\
\hline MW-1009 & $\mathrm{NC}$ & - & - & $\mathrm{NC}$ & - & - \\
\hline MW-1013 & 0.037 & $1.0 \times 10^{-6}$ & $1.6 \times 10^{-9}$ & 0.013 & $3.6 \times 10^{-7}$ & $5.7 \times 10^{-10}$ \\
\hline MW-1014 & $\mathrm{NC}$ & - & - & $\mathrm{NC}$ & - & - \\
\hline MW-1015 & 0.029 & $8.0 \times 10^{-7}$ & $1.3 \times 10^{-9}$ & 0.21 & $5.8 \times 10^{-6}$ & $9.2 \times 10^{-9}$ \\
\hline MW-1016 & $\mathrm{NC}$ & - & - & 0.047 & $1.3 \times 10^{-6}$ & $2.1 \times 10^{-9}$ \\
\hline MW-1026 & $\mathrm{NC}$ & - & - & NC & - & - \\
\hline$M W-1027$ & 4.3 & $1.2 \times 10^{-4}$ & $1.9 \times 10^{-7}$ & 2.2 & $6.0 \times 10^{-5}$ & $9.6 \times 10^{-8}$ \\
\hline MW-1028 & $\mathrm{NC}$ & - & - & NC & - & - \\
\hline MW-1029 & NC & - & - & 0.011 & $3.1 \times 10^{-7}$ & $5.0 \times 10^{-10}$ \\
\hline MW-1030 & 0.026 & $7.1 \times 10^{-7}$ & $1.1 \times 10^{-9}$ & 0.032 & $8.7 \times 10^{-7}$ & $1.4 \times 10^{-9}$ \\
\hline MW-1031 & $\mathrm{NC}$ & - & - & $\mathrm{NC}$ & - & - \\
\hline MW-1032 & 0.27 & $7.4 \times 10^{-6}$ & $1.2 \times 10^{-8}$ & 0.069 & $1.9 \times 10^{-6}$ & $3.0 \times 10^{-9}$ \\
\hline MW-1035 & $\mathrm{NC}$ & - & - & $\mathrm{NC}$ & - & - \\
\hline MW-1036 & $\mathrm{NC}$ & - & - & $N C$ & - & - \\
\hline$M W-1037$ & 0.018 & $4.8 \times 10^{-7}$ & $7.7 \times 10^{-10}$ & $\mathrm{NC}$ & - & - \\
\hline MW-1038 & NC & - & - & $\mathrm{NC}$ & - & - \\
\hline MW-1039 & $\mathrm{NC}$ & - & - & $\mathrm{NC}$ & - & - \\
\hline MW-1040 & NC & - & - & $\mathrm{NC}$ & - & - \\
\hline MW-104I & $\mathrm{NC}$ & - & - & $\mathrm{NC}$ & - & - \\
\hline MW-1045 & $\mathrm{NC}$ & - & - & $\mathrm{NC}$ & - & - \\
\hline MW-1046 & $\mathrm{NC}$ & - & - & $\mathrm{NC}$ & - & - \\
\hline MW-1047 & $\mathrm{NC}$ & - & - & $\mathrm{NC}$ & - & - \\
\hline MW-1048 & $\mathrm{NC}$ & - & - & $\mathrm{NC}$ & - & - \\
\hline MW-1049 & $\mathrm{NC}$ & - & - & $\mathrm{NC}$ & - & - \\
\hline
\end{tabular}

a Nitroaromatic compounds were not detected in wells located south of the slough.

${ }^{b}$ Exposure point concentration $(E P C)=$ upper confidence limit $(U C L)$ or the maximum value reported for each well from the data collected since 1995.

c $\mathrm{NC}=$ not calculated because parameter not detected in this well.

i A hyphen (-) indicates that parameter was not detecied. 
TABLE 3.10 Estimated Carcinogenic Intakes of Nitroaromatic Compound COPCs for a Hypothetical Future Resident ${ }^{\mathrm{a}}$

\begin{tabular}{|c|c|c|c|c|c|c|c|c|c|}
\hline \multirow[b]{3}{*}{ Well ID } & \multicolumn{3}{|c|}{$2,4,6-\mathrm{TNT}$} & \multicolumn{3}{|c|}{ 2,4-DNT } & \multicolumn{3}{|c|}{ 2,6-DNT } \\
\hline & \multirow[b]{2}{*}{$\begin{array}{c}\mathrm{EPC}^{\mathrm{b}} \\
(\mu \mathrm{g} / \mathrm{L})\end{array}$} & \multicolumn{2}{|c|}{ Intake (mg/kg-d) } & \multirow[b]{2}{*}{$\begin{array}{c}\mathrm{EPC}^{\mathrm{b}} \\
(\mu \mathrm{g} / \mathrm{L})\end{array}$} & \multicolumn{2}{|c|}{ Intake $(\mathrm{mg} / \mathrm{kg}-\mathrm{d})$} & \multirow[b]{2}{*}{$\begin{array}{c}\mathrm{EPC}^{\mathrm{b}} \\
(\mu \mathrm{g} / \mathrm{L})\end{array}$} & \multicolumn{2}{|c|}{ Intake (mg/kg-d) } \\
\hline & & Ingestion & Dermal & & Ingestion & Dermal & & Ingestion & Dermal \\
\hline \multicolumn{10}{|c|}{ North of Slough } \\
\hline MW-1002 & 34 & $4.0 \times 10^{-4}$ & $6.4 \times 10^{-7}$ & 0.13 & $1.6 \times 10^{-6}$ & $2.5 \times 10^{-9}$ & 12 & $1.4 \times 10^{-4}$ & $2.2 \times 10^{-7}$ \\
\hline MW-1004 & 9.9 & $1.2 \times 10^{-4}$ & $1.9 \times 10^{-7}$ & 0.71 & $8.3 \times 10^{-6}$ & $1.3 \times 10^{-8}$ & 0.94 & $1.1 \times 10^{-5}$ & $1.8 \times 10^{-8}$ \\
\hline MW-1005 & $\mathrm{NC}^{\mathrm{c}}$ & $-d$ & - & $\mathrm{NC}$ & - & - & $\mathrm{NC}$ & - & - \\
\hline MW-1006 & 12 & $1.4 \times 10^{-4}$ & $2.2 \times 10^{-7}$ & 0.45 & $5.3 \times 10^{-6}$ & $8.5 \times 10^{-9}$ & 2.3 & $2.7 \times 10^{-5}$ & $4.4 \times 10^{-8}$ \\
\hline MW-1007 & 0.078 & $9.2 \times 10^{-7}$ & $1.5 \times 10^{-9}$ & $\mathrm{NC}$ & - & - & 0.024 & $2.8 \times 10^{-7}$ & $4.5 \times 10^{-10}$ \\
\hline MW- 1008 & 0.19 & $2.3 \times 10^{-6}$ & $3.6 \times 10^{-9}$ & $\mathrm{NC}$ & - & - & 0.043 & $5.0 \times 10^{-7}$ & $8.1 \times 10^{-10}$ \\
\hline MW-1009 & $\mathrm{NC}$ & - & - & $\mathrm{NC}$ & - & - & $\mathrm{NC}$ & - & - \\
\hline MW-1013 & $\mathrm{NC}$ & - & - & 0.037 & $4.3 \times 10^{-7}$ & $6.9 \times 10^{-10}$ & 0.013 & $1.5 \times 10^{-7}$ & $2.5 \times 10^{-10}$ \\
\hline MW-1014 & $\mathrm{NC}$ & - & - & NC & - & - & $\mathrm{NC}$ & - & - \\
\hline MW-1015 & 2.9 & $3.4 \times 10^{-5}$ & $5.4 \times 10^{-7}$ & 0.029 & $3.4 \times 10^{-7}$ & $5.5 \times 10^{-10}$ & 0.21 & $2.5 \times 10^{-6}$ & $3.9 \times 10^{-9}$ \\
\hline MW-1016 & 0.30 & $3.6 \times 10^{-6}$ & $5.7 \times 10^{-9}$ & $\mathrm{NC}$ & - & - & 0.047 & $5.5 \times 10^{-7}$ & $8.9 \times 10^{-10}$ \\
\hline MW-1026 & $\mathrm{NC}$ & - & - & $\mathrm{NC}$ & - & - & $\mathrm{NC}$ & - & - \\
\hline MW-1027 & 1.1 & $1.3 \times 10^{-5}$ & $2.1 \times 10^{-8}$ & 4.3 & $5.0 \times 10^{-5}$ & $8.0 \times 10^{-8}$ & 2.2 & $2.6 \times 10^{-5}$ & $4.1 \times 10^{-8}$ \\
\hline$M W-1028$ & $\mathrm{NC}$ & - & - & $\mathrm{NC}$ & - & - & $\mathrm{NC}$ & - & - \\
\hline MW-1029 & NC & - & - & NC & - & - & 0.011 & $1.3 \times 10^{-7}$ & $2.1 \times 10^{-10}$ \\
\hline $\mathrm{MW}-1030$ & 0.022 & $2.6 \times 10^{-7}$ & $4.1 \times 10^{-9}$ & 0.026 & $3.0 \times 10^{-7}$ & $4.9 \times 10^{-10}$ & 0.032 & $3.7 \times 10^{-7}$ & $6.0 \times 10^{-10}$ \\
\hline$M W-1031$ & $\mathrm{NC}$ & - & - & NC & - & - & NC & - & - \\
\hline$M W \cdot 1032$ & 0.43 & $5.0 \times 10^{-6}$ & $8.1 \times 10^{-9}$ & 0.27 & $3.2 \times 10^{-6}$ & $5.1 \times 10^{-9}$ & 0.069 & $8.1 \times 10^{-7}$ & $1.3 \times 10^{-9}$ \\
\hline MW-1035 & $\mathrm{NC}$ & - & - & $\mathrm{NC}$ & - & - & $\mathrm{NC}$ & - & - \\
\hline MW-1036 & $\mathrm{NC}$ & - & - & $\mathrm{NC}$ & - & - & $\mathrm{NC}$ & - & - \\
\hline MW-1037 & $\mathrm{NC}$ & - & - & 0.018 & $2.1 \times 10^{-7}$ & $3.3 \times 10^{-10}$ & $\mathrm{NC}$ & - & - \\
\hline MW-1038 & $\mathrm{NC}$ & - & - & $\mathrm{NC}$ & - & - & $\mathrm{NC}$ & - & - \\
\hline$M W-1039$ & $\mathrm{NC}$ & - & - & $\mathrm{NC}$ & - & - & $\mathrm{NC}$ & - & - \\
\hline MW-1040 & $\mathrm{NC}$ & - & - & $\mathrm{NC}$ & - & - & $\mathrm{NC}$ & - & - \\
\hline MW-104I & $\mathrm{NC}$ & - & - & $\mathrm{NC}$ & - & - & $\mathrm{NC}$ & - & - \\
\hline MW-1045 & $\mathrm{NC}$ & - & - & $\mathrm{NC}$ & - & - & $\mathrm{NC}$ & - & - \\
\hline MW-1046 & $\mathrm{NC}$ & - & - & NC & - & - & $\mathrm{NC}$ & - & - \\
\hline MW-1047 & $\mathrm{NC}$ & - & - & $\mathrm{NC}$ & - & - & $\mathrm{NC}$ & - & - \\
\hline$M W-1048$ & NC & - & - & NC & - & - & $\mathrm{NC}$ & - & - \\
\hline MW-1049 & $\mathrm{NC}$ & - & - & NC & - & - & $\mathrm{NC}$ & - & - \\
\hline
\end{tabular}

a Nitroaromatic compounds were not detected south of the slough.

b Exposure point concentration $(\mathrm{EPC})=$ upper confidence limit $(\mathrm{UCL})$ or the maximum value reported for each well from the data collected since 1995 .

- $\mathrm{NC}=$ not calculated because parameter not detected in this well.

A A hyphen (-) indicates that parameter was not detected. 
TABLE 3.11 Species-Specific Exposure Factors for Ecological Receptors Using the QROU

\begin{tabular}{|c|c|c|c|c|}
\hline \multirow[b]{2}{*}{ Parameter } & \multicolumn{4}{|c|}{ Species-Specific Exposure Factor ${ }^{\mathrm{a}}$} \\
\hline & Mallard Duck & Great Blue Heron & Bald Eagle & White-Tailed Deer ${ }^{\mathrm{b}}$ \\
\hline Mean body weight $(\mathrm{kg})$ & 1.10 & 2.23 & 4.50 & 90.0 \\
\hline Life expectancy ${ }^{c}(y r)$ & 15 & 15 & 20 & 20 \\
\hline Home range (ha) & 289 & 8,100 & 3,494 & 160.0 \\
\hline Food ingestion rate $(\mathrm{kg} / \mathrm{d})$ & $0.0619^{d}$ & $0.401^{\mathrm{d}}$ & $0.540^{\mathrm{d}}$ & 0.86 \\
\hline Diet fraction & $\begin{array}{l}64 \% \text { invertebrates } \\
34 \% \text { vegetation } \\
2 \% \text { sediment }\end{array}$ & $\begin{array}{l}85 \% \text { fish } \\
10 \% \text { amphibians } \\
5 \% \text { sediment }\end{array}$ & $\begin{array}{l}50 \% \text { waterfowl } \\
27 \% \text { fish } \\
23 \% \text { carrion }\end{array}$ & $100 \%$ vegetation \\
\hline Water ingestion rate (g/g-d) & 0.055 & 0.045 & 0.036 & 0.06 \\
\hline
\end{tabular}

a All values from EPA Wildlife Exposure Factors Handbook (EPA 1993), unless otherwise noted.

b Exposure factors from Schwartz and Schwartz (1981).

c From Terres (1980).

d Derived using allometric equations in EPA (1993). 
TABLE 3.12 Estimated Contaminant Doses for the Mallard Duck Foraging at Femme Osage Slough

\begin{tabular}{|c|c|c|c|c|}
\hline \multirow[b]{2}{*}{ Contaminant } & \multicolumn{4}{|c|}{ Applied Daily Dose $^{\mathrm{a}}(\mathrm{mg} / \mathrm{kg}-\mathrm{d})$} \\
\hline & $\begin{array}{c}\text { Water } \\
\text { Ingestion }\end{array}$ & $\begin{array}{l}\text { Sediment } \\
\text { Ingestion }\end{array}$ & $\begin{array}{c}\text { Food } \\
\text { Ingestion }\end{array}$ & Total \\
\hline \multicolumn{5}{|l|}{ Metals } \\
\hline Aluminum & 0.0012 & 0.0668 & 3.2760 & 3.3460 \\
\hline Arsenic & $<0.0001$ & 0.0001 & 0.0040 & 0.0041 \\
\hline Barium & 0.0001 & 0.0012 & 0.0580 & 0.0593 \\
\hline Calcium & 0.0107 & 0.1138 & 5.5750 & 5.6990 \\
\hline Cadmium & $<0.0001$ & $<0.0001$ & 0.0007 & 0.0008 \\
\hline Chloride & 0.0037 & 0.0001 & 0.0065 & 0.0103 \\
\hline Chromium & $<0.0001$ & 0.0002 & 0.0083 & 0.0085 \\
\hline Copper & $<0.0001$ & 0.0001 & 0.0049 & 0.0050 \\
\hline Iron & 0.0013 & 0.0942 & 4.6158 & 4.7113 \\
\hline Lead & $<0.0001$ & 0.0002 & 0.0079 & 0.0081 \\
\hline Magnesium & 0.0024 & 0.0179 & 0.8770 & 0.8973 \\
\hline Manganese & 0.0002 & 0.0036 & 0.1787 & 0.1825 \\
\hline Mercury & $<0.0001$ & $<0.0001$ & 0.0002 & 0.0003 \\
\hline Molybdenum & $\mathrm{ND}^{\mathrm{a}}$ & $<0.0001$ & 0.0007 & 0.0007 \\
\hline Nickel & $<0.0001$ & $<0.0001$ & 0.0045 & 0.0045 \\
\hline Potassium & 0.0010 & 0.0115 & 0.5658 & 0.5783 \\
\hline Selenium & $<0.0001$ & $<0.0001$ & 0.0045 & 0.0045 \\
\hline Sodium & 0.0023 & 0.0008 & 0.0405 & 0.0436 \\
\hline Thallium & $<0.0001$ & $<0.0001$ & 0.0004 & 0.0004 \\
\hline Uranium, total & 0.0010 & $<0.0001$ & 0.0029 & 0.0039 \\
\hline Vanadium & $<0.0001$ & 0.0001 & 0.0072 & 0.0073 \\
\hline Zinc & $<0.0001$ & 0.0006 & 0.0298 & 0.0304 \\
\hline \multicolumn{5}{|l|}{ Inorganic anion } \\
\hline Nitrate & 0.0016 & ND & ND & 0.0016 \\
\hline \multicolumn{5}{|c|}{ Nitroaromatic compounds } \\
\hline $1,3,5-\mathrm{TNB}$ & ND & $<0.0001$ & $<0.0001$ & $<0.0001$ \\
\hline $2,4,6-\mathrm{TNT}$ & ND & $<0.0001$ & $<0.0001$ & $<0.0001$ \\
\hline 2,4-DNT & ND & $<0.0001$ & $<0.0001$ & $<0.0001$ \\
\hline 2,6-DNT & ND & $<0.0001$ & $<0.0001$ & $<0.0001$ \\
\hline 1,3-DNB & ND & $<0.0001$ & $<0.0001$ & $<0.0001$ \\
\hline Nitrobenzene & ND & $<0.0001$ & $<0.0001$ & $<0.0001$ \\
\hline
\end{tabular}

a $\mathrm{ND}=$ not detected 
TABLE 3.13 Estimated Contaminant Doses for the Great Blue Heron Foraging at Femme Osage Slough

\begin{tabular}{|c|c|c|c|c|}
\hline \multirow[b]{2}{*}{ Contaminant } & \multicolumn{4}{|c|}{ Applied Daily Dose $^{\mathrm{a}}(\mathrm{mg} / \mathrm{kg}-\mathrm{d})$} \\
\hline & $\begin{array}{c}\text { Water } \\
\text { Ingestion }\end{array}$ & $\begin{array}{l}\text { Sediment } \\
\text { Ingestion }\end{array}$ & $\begin{array}{c}\text { Food } \\
\text { Ingestion }\end{array}$ & Total \\
\hline \multicolumn{5}{|l|}{ Metals } \\
\hline Aluminum & 0.0003 & 0.1780 & 3.3824 & 3.5607 \\
\hline Arsenic & $<0.0001$ & 0.0002 & 0.0037 & 0.0039 \\
\hline Barium & $<0.0001$ & 0.0031 & 0.0594 & 0.0625 \\
\hline Calcium & 0.0029 & 0.3030 & 5.7570 & 6.0629 \\
\hline Cadmium & $<0.0001$ & $<0.0001$ & 0.0007 & 0.0007 \\
\hline Chloride & 0.0010 & 0.0004 & 0.0067 & 0.0081 \\
\hline Chromium & $<0.0001$ & 0.0004 & 0.0085 & 0.0089 \\
\hline Copper & $<0.0001$ & 0.0003 & 0.0050 & 0.0053 \\
\hline Iron & 0.0003 & 0.2508 & 4.7661 & 5.0172 \\
\hline Lead & $<0.0001$ & 0.0004 & 0.0082 & 0.0086 \\
\hline Magnesium & 0.0007 & 0.0476 & 0.9054 & 0.9537 \\
\hline Manganese & $<0.0001$ & 0.0097 & 0.1845 & 0.1942 \\
\hline Mercury & $<0.0001$ & $<0.0001$ & 0.0002 & 0.0002 \\
\hline Molybdenum & $\mathrm{ND}^{\mathrm{a}}$ & $<0.0001$ & 0.0007 & 0.0007 \\
\hline Nickel & $<0.0001$ & 0.0002 & 0.0047 & 0.0049 \\
\hline Potassium & 0.0003 & 0.0307 & 0.5842 & 0.6152 \\
\hline Selenium & $<0.0001$ & 0.0002 & 0.0046 & 0.0048 \\
\hline Sodium & 0.0007 & 0.0022 & 0.0419 & 0.0448 \\
\hline Thallium & $<0.0001$ & $<0.0001$ & 0.0004 & 0.0004 \\
\hline Uranium, total & 0.0003 & 0.0002 & 0.0031 & 0.0036 \\
\hline Vanadium & $<0.0001$ & 0.0004 & 0.0075 & 0.0079 \\
\hline Zinc & $<0.0001$ & 0.0016 & 0.0307 & 0.0323 \\
\hline \multicolumn{5}{|l|}{ Inorganic anion } \\
\hline Nitrate & 0.0004 & ND & ND & 0.0004 \\
\hline \multicolumn{5}{|c|}{ Nitroaromatic compounds } \\
\hline $1,3,5-\mathrm{TNB}$ & ND & $<0.0001$ & $<0.0001$ & $<0.0001$ \\
\hline $2,4,6-\mathrm{TNT}$ & ND & $<0.0001$ & $<0.0001$ & $<0.0001$ \\
\hline 2,6-DNT & ND & $<0.0001$ & $<0.0001$ & $<0.0001$ \\
\hline 2,4-DNT & ND & $<0.0001$ & $<0.0001$ & $<0.0001$ \\
\hline 1,3-DNB & ND & $<0.0001$ & $<0.0001$ & $<0.0001$ \\
\hline Nitrobenzene & ND & $<0.0001$ & $<0.0001$ & $<0.0001$ \\
\hline
\end{tabular}

a $\mathrm{ND}=$ not detected. 
TABLE 3.14 Estimated Contaminant Doses for the Bald Eagle Foraging at Femme Osage Slough

\begin{tabular}{|c|c|c|c|}
\hline \multirow[b]{2}{*}{ Contaminant } & \multicolumn{3}{|c|}{ Applied Daily Dose ${ }^{\mathrm{a}}(\mathrm{mg} / \mathrm{kg}-\mathrm{d})$} \\
\hline & $\begin{array}{c}\text { Water } \\
\text { Ingestion }\end{array}$ & $\begin{array}{c}\text { Food } \\
\text { Ingestion }\end{array}$ & Total \\
\hline \multicolumn{4}{|l|}{ Metals } \\
\hline Aluminum & 0.0008 & 1.9249 & 1.9302 \\
\hline Arsenic & $<0.0001$ & 0.0021 & 0.0021 \\
\hline Barium & $<0.0001$ & 0.0338 & 0.0338 \\
\hline Calcium & 0.0070 & 3.2767 & 3.2837 \\
\hline Cadmium & $<0.0001$ & 0.0004 & 0.0004 \\
\hline Chloride & 0.0024 & 0.0038 & 0.0062 \\
\hline Chromium & $<0.0001$ & 0.0049 & 0.0049 \\
\hline Copper & $<0.0001$ & 0.0029 & 0.0029 \\
\hline Iron & 0.0008 & 2.7123 & 2.7131 \\
\hline Lead & $<0.0001$ & 0.0047 & 0.0047 \\
\hline Magnesium & 0.0016 & 0.5152 & 0.5168 \\
\hline Manganese & 0.0001 & 0.1050 & 0.1051 \\
\hline Mercury & $<0.0001$ & 0.0001 & 0.0001 \\
\hline Molybdenum & $\mathrm{ND}^{\mathrm{a}}$ & 0.0004 & 0.0004 \\
\hline Nickel & $<0.0001$ & 0.0027 & 0.0027 \\
\hline Potassium & 0.0007 & 0.3325 & 0.3332 \\
\hline Selenium & $<0.0001$ & 0.0026 & 0.0026 \\
\hline Sodium & 0.0018 & 0.0238 & 0.0256 \\
\hline Thallium & $<0.0001$ & 0.0002 & 0.0002 \\
\hline Uranium, total & 0.0006 & 0.0017 & 0.0023 \\
\hline Vanadium & $<0.0001$ & 0.0042 & 0.0042 \\
\hline Zinc & $<0.0001$ & 0.0175 & 0.0175 \\
\hline \multicolumn{4}{|l|}{ Inorganic anion } \\
\hline Nitrate & 0.0011 & ND & 0.0011 \\
\hline \multicolumn{4}{|c|}{ Nitroaromatic compounds } \\
\hline $1,3,5-\mathrm{TNB}$ & ND & $<0.0001$ & $<0.0001$ \\
\hline $2,4,6-\mathrm{TNT}$ & ND & $<0.0001$ & $<0.0001$ \\
\hline 2,6-DNT & ND & $<0.0001$ & $<0.0001$ \\
\hline 2,4-DNT & ND & $<0.0001$ & $<0.0001$ \\
\hline 1,3-DNB & ND & $<0.0001$ & $<0.0001$ \\
\hline Nitrobenzene & ND & $<0.0001$ & $<0.0001$ \\
\hline
\end{tabular}

a $\mathrm{ND}=$ not detected. 
TABLE 3.15 Estimated Contaminant Doses for the White-Tailed Deer Drinking from Femme Osage Slough and Little Femme Osage Creek

\begin{tabular}{|c|c|c|c|}
\hline \multirow[b]{2}{*}{ Contaminant } & \multicolumn{3}{|c|}{ Applied Daily Dose ${ }^{\mathrm{a}}(\mathrm{mg} / \mathrm{kg}-\mathrm{d})$} \\
\hline & $\begin{array}{c}\text { Femme Osage } \\
\text { Slough }\end{array}$ & $\begin{array}{l}\text { Little Femme } \\
\text { Osage Creek }\end{array}$ & Total \\
\hline \multicolumn{4}{|l|}{ Metals } \\
\hline Aluminum & 0.0220 & 0.0008 & 0.0228 \\
\hline Antimony & $\mathrm{ND}^{\mathrm{a}}$ & 0.0001 & 0.0001 \\
\hline Arsenic & $<0.0001$ & $<0.0001$ & $<0.0001$ \\
\hline Barium & 0.001 & 0.0008 & 0.0018 \\
\hline Calcium & 0.2048 & 0.562 & 0.7668 \\
\hline Cadmium & $<0.0001$ & $<0.0001$ & $<0.0001$ \\
\hline Chloride & 0.070 & 0.035 & 0.105 \\
\hline Chromium & $<0.0001$ & 0.0002 & 0.0002 \\
\hline Copper & $<0.0001$ & ND & $<0.0001$ \\
\hline Iron & 0.0250 & 0.0098 & 0.0348 \\
\hline Lead & $<0.0001$ & $<0.0001$ & $<0.0001$ \\
\hline Magnesium & 0.0470 & 0.055 & 0.102 \\
\hline Manganese & 0.0040 & 0.0014 & 0.0054 \\
\hline Mercury & $<0.0001$ & $<0.0001$ & $<0.0001$ \\
\hline Nickel & $<0.0001$ & $<0.0001$ & $<0.0001$ \\
\hline Potassium & 0.019 & 0.012 & 0.031 \\
\hline Selenium & $<0.0001$ & $<0.0001$ & $<0.0001$ \\
\hline Sodium & 0.0520 & 0.0350 & 0.0870 \\
\hline Thallium & $<0.0001$ & $<0.0001$ & $<0.0001$ \\
\hline Uranium, total & 0.0200 & $<0.0001$ & 0.0200 \\
\hline Vanadium & $<0.0001$ & $<0.0001$ & $<0.0001$ \\
\hline Zinc & 0.0003 & 0.0002 & 0.0005 \\
\hline \multicolumn{4}{|l|}{ Inorganic anion } \\
\hline Nitrate & 0.0310 & 0.0281 & 0.0591 \\
\hline Sulfate & 0.9216 & 0.1957 & 1.1173 \\
\hline \multicolumn{4}{|c|}{ Nitroaromatic compounds } \\
\hline $1,3,5-\mathrm{TNB}$ & ND & $<0.0001$ & $<0.0001$ \\
\hline $2,4,6-\mathrm{TNT}$ & ND & $<0.0001$ & $<0.0001$ \\
\hline 2,6-DNT & ND & $<0.0001$ & $<0.0001$ \\
\hline
\end{tabular}


TABLE 3.16 Estimated Radiological Daily Dose Rates to Wildlife Receptors Ingesting Food, Surface Water, and Sediment from Femme Osage Slough

Daily Dose (rad/d)

\begin{tabular}{lccccc}
\multicolumn{1}{c}{ Receptor } & $\begin{array}{c}\text { Slough } \\
\text { Site Use } \\
\text { Factor }^{\mathrm{a}}\end{array}$ & $\begin{array}{c}\text { Surface Water } \\
\text { Ingestion }\end{array}$ & $\begin{array}{c}\text { Sediment } \\
\text { Ingestion }\end{array}$ & $\begin{array}{c}\text { Food } \\
\text { Ingestion }\end{array}$ & Total \\
\hline Mallard & 0.003 & $1.8 \times 10^{-4}$ & $8.8 \times 10^{-6}$ & $1.2 \times 10^{-3}$ & $1.4 \times 10^{-3}$ \\
Great blue heron & 0.001 & $5.0 \times 10^{-5}$ & $2.4 \times 10^{-5}$ & $2.0 \times 10^{-4}$ & $2.7 \times 10^{-4}$ \\
Bald eagle & 0.003 & $1.6 \times 10^{-4}$ & $\mathrm{NE}^{\mathrm{b}}$ & $1.7 \times 10^{-3}$ & $1.8 \times 10^{-3}$ \\
White-tailed deer & 0.05 & $4.5 \times 10^{-3}$ & $\mathrm{NE}$ & $4.1 \times 10^{-6}$ & $4.5 \times 10^{-3}$ \\
\hline
\end{tabular}

a The site use factor is the ratio of the area of the Femme Osage Slough ( 2.3 ha) to the total area of all surface waters present within the home range of the receptor species. The available surface water area was estimated by centering the home range of each receptor on the slough and identifying all surface waters present within a radius of the slough that encompasses the area of the home range.

b $\mathrm{NE}=\mathrm{A}$ dose was not estimated because no sediment ingestion route was identified for the receptor. 


\section{TOXICITY ASSESSMENT}

Toxicity of the radioactive and chemical COPCs identified for the QROU is discussed in Sections 4.1 and 4.2, respectively. Methods for evaluating toxicity to humans are discussed in Section 4.3.

\subsection{RADIATION TOXICITY}

\subsubsection{Human Health}

Only at relatively high doses or at high dose rates over large populations have radiation health effects been confirmed in humans. Health effects are presumed to occur at low doses as well, but can only be estimated statistically. Potential radiological health risks are expressed as the increased incidence of cancer in the exposed population. Radiation exposure pathways can be separated into either external or internal exposure. External exposure occurs when the radioactive material is outside the body. Internal exposure occurs when the radioactive material enters the body by inhalation or ingestion.

Alpha, beta, and gamma radiations are released during the radioactive decay of radionuclides in the uranium-238, thorium-232, and uranium-235 decay series. Each type of radiation differs in its physical properties and its ability to induce damage in biological tissue. Within the body, alpha particles are the most effective of the three types of radiation in damaging cells because their energy is completely absorbed by tissue. Beta particles are primarily an internal hazard; however, in cases of external skin exposure, very energetic beta particles can penetrate to living skin cells, thus representing an external hazard as well. Gamma radiation is primarily an external hazard because it can penetrate tissue and reach internal organs. Alpha and beta particles are the principal concern for internal exposures because their energy is absorbed in cells before the particles leave the body; gamma rays are most likely to leave the body without depositing a large fraction of their energy.

\subsubsection{Ecological Health}

Identifying the effects of radionuclides on organisms in the natural environment is complicated because (1) various sources of ionizing radiation are possible; (2) exposure can be internal, external, or both; (3) each radionuclide has unique physical and chemical properties; (4) ecological receptors have different mobilities and use a variety of habitats; and (5) current concentrations of radionuclides in most areas are too low to detect effects on biota populations and 
communities, even in such areas as weapons testing sites (Whicker and Schultz 1982a-b). Possible effects to ecological receptors from acute or chronic radiological exposure include mortality, physiological and pathological changes, and developmental and reproductive effects (National Council on Radiation Protection and Measurements [NCRP] 1991; International Atomic Energy Agency [IAEA] 1992; Rose 1992).

For acute exposure to ionizing radiation, aquatic invertebrates tend to be more resistant than aquatic vertebrates. The most sensitive periods in the life cycles of aquatic organisms are the early developmental stages, with radiation sensitivity generally decreasing with increasing development (NCRP 1991). The reproductive and early developmental stages of aquatic organisms are also most sensitive to chronic irradiation, and deleterious effects of chronic irradiation have not been observed in natural populations at dose rates of $1 \mathrm{rad} / \mathrm{d}$ or less (NCRP 1991).

Similar sensitivity and effects have been identified for terrestrial wildlife (IAEA 1992). Terrestrial invertebrates are much less sensitive to ionizing radiation than are terrestrial vertebrates, requiring about 100 times the dose needed for vertebrates to induce mortality. Among terrestrial species, lethal acute doses and sensitivity to chronic radiation vary widely among different taxa, with birds, mammals, and a few tree species being among the most sensitive biota. Acute doses of less than $10 \mathrm{rad}$ are considered unlikely to produce persistent, measurable deleterious changes in populations or communities of terrestrial plants or animals (IAEA 1992). Chronic dose rates of less than $0.1 \mathrm{rad} / \mathrm{d}$ for animal populations and less than $1 \mathrm{rad} / \mathrm{d}$ for plant populations do not appear likely to cause observable changes in terrestrial species. As for aquatic biota, the reproductive and early developmental stages of terrestrial biota are most sensitive to irradiation.

\subsection{CHEMICAL TOXICITY}

\subsubsection{Human Health}

The chemical COPCs in the QROU include metals, nitroaromatic compounds, and PCBs. Information on characteristics of COPCs is presented below.

Antimony is typically present in soil as sulfide and oxide compounds. Industrially, antimony is used in many alloys. It has been administered orally to humans and animals as both an emetic and an antiparasitic agent. Toxic effects that have been observed in humans are associated mainly with occupational exposures.

Arsenic compounds are widely used as pesticides. Although inorganic arsenic has been used as a poison for centuries, it is an essential nutrient for several animal species and is believed to be essential for humans. Typical human exposures to arsenic from background sources range from 20 
to $70 \mu \mathrm{g} / \mathrm{d}$, with food being the major source. Noncarcinogenic toxic effects of arsenic ingestion at levels greater than about $20 \mu \mathrm{g} / \mathrm{kg}$-d include skin disorders, severe irritation of the gastrointestinal tract, anemia, nerve degeneration, and toxicity to the liver, kidney, and heart.

In soil, beryllium is generally present in insoluble, immobile forms. Beryllium compounds are poorly absorbed from the digestive tract and through the skin. Occupational exposure to beryllium oxide at levels greater than $2 \mu \mathrm{g} / \mathrm{m}^{3}$ can result in scarring of the lungs, shortness of breath, and reduction in lung volume. Data on developmental and reproductive toxicity are lirnited; however, in one study of pregnant rats administered beryllium chloride, increases in fetal mortality and internal abnormalities in the offspring were reported.

Chromium is present in the environment as chromium, trivalent chromium (III), and hexavalent chromium (VI). Chromium III occurs naturally in the environment and is an essential nutrient, whereas chromium and chromium VI generally result from industrial processes. The principal toxicological hazard of environmental chromium is associated with exposure to chromium VI. Effects observed following exposure to high levels of chromium VI include irritation of the nasal mucosa, perforation of the nasal septum, skin ulcers, and irritation of the gastrointestinal tract.

Lead can result in varied toxicologic effects, depending on the level of exposure. In the absence of an oral reference dose (RfD) for lead, the EPA has developed an uptake/biokinetic model to estimate blood levels of lead on the basis of total lead uptake from exposures via diet, drinking water, air, soil, and paint. The application of this model to potential exposures at the quarry area (i.e., slough surface water) is discussed briefly in Section 5.3.3. At blood levels greater than $40 \mu \mathrm{g} / \mathrm{dL}$, lead can cause miscarriage, sterility in males, anemia, and damage to the central nervous system and kidneys. The fetus and young children are particularly sensitive to lead toxicity. Some experts believe there is no adverse effects threshold for lead in children. Even low-level. lead exposure (e.g., as low as $10 \mu \mathrm{g} / \mathrm{dL}$ ) during early childhood can cause impaired intellectual and neurobehavioral development.

Manganese is an essential dietary nutrient for humans and is present in many foods. Studies of humans and experimental animals suggest that oral exposure to elevated levels of manganese can result in decreased fertility and in effects on the cardiovascular and central nervous systems.

Inorganic and organic forms of mercury have been found to be toxic to humans and experimental animals. In general, the organic forms are more toxic than the inorganic forms. Human studies indicate that the kidney and central nervous system are the main sites affected by mercury; however, the degree to which these systems are affected depends on the chemical form of mercury and the route of exposure. 
Selenium and most of its compounds are not considered to be carcinogenic; in fact, several studies suggest that normal amounts of dietary selenium may protect against cancer. However, selenium sulfide has been shown to be carcinogenic in animals via ingestion.

Experimental studies suggest that thallium induces toxic effects in the reproductive system. Chronic thallium intoxication in humans during pregnancy has also been reported to cause malformations and central nervous system defects in offspring.

Although natural uranium is radioactive, the primary health effect associated with exposure is kidney damage caused by chemical toxicity. About $5 \%$ of the soluble salts of uranium are absorbed via ingestion. Kidney toxicity, which is the main health effect of concern for exposure to soluble uranium, may be reversible, depending on the level of exposure.

The oral toxicity of vanadium increases with increasing valency; pentavalent vanadium is the most toxic. Excess ingestion of vanadium has caused gastrointestinal disturbances, nervous system effects, and abnormalities in renal enzyme systems. Vanadium is absorbed more efficiently by inhalation than ingestion. Estimates of oral absorption of vanadium range from 0.1 to $2 \%$.

In general, zinc deficiencies are of greater health significance than overexposure to zinc. In humans, absorption of zinc from the gastrointestinal tract is controlled by homeostatic mechanisms; approximately 20 to $50 \%$ of ingested zinc is absorbed.

Health hazards associated with nitroaromatic compounds include methemoglobinemia and toxic effects to the liver, kidneys, and nervous system. Studies in humans indicate that nitroaromatic compounds are absorbed following inhalation and ingestion, and that these compounds are capable of penetrating the skin.

\subsubsection{Ecological Health}

The COECs include metals and nitroaromatic compounds. Metals have been reported to cause a variety of lethal and sublethal effects in aquatic and terrestrial biota (see Sample et al. 1996; Suter and Tsao 1996). The toxicity of these contaminants depends on physical and chemical factors in the environment, such as $\mathrm{pH}$ and the presence of complexing agents, as well as on the specific taxon being exposed. In vegetation, reported adverse effects of metal exposure include reduced chlorophyll concentrations, reduced growth and biomass production, and reduced seed production and germination. In aquatic biota, metal exposure has been shown to affect reproduction, ion exchange across gill surfaces, behavior, and survival of all life stages. In terrestrial biota, metal exposure may result in developmental abnormalities; renal and central nervous system damage; altered blood chemistry; altered metabolic processes; and behavioral changes affecting foraging, susceptibility to predators, and reproduction. 
Relatively little information is available regarding the effects of nitroaromatic compounds on natural populations of plants, fish, and wildlife (see Talmadge and Opresko 1996). Laboratory studies have shown exposure to nitroaromatic compounds to elicit a variety of responses in aquatic and terrestrial biota. Effects of exposure on fish and aquatic invertebrates include increased adult mortality, reduced egg production and survival, decreased survival of early life stages, reduced body weights and lengths, and increased physical deformities. Adverse effects on aquatic plants may include depressed growth and cellular deformities. Effects of nitroaromatic compounds on terrestrial wildlife may include reduced body weights, changes in blood chemistry and cellular composition, changes in metabolic pathways and processes, renal and liver malfunction, and organ necroses and lesions. Reported effects to terrestrial vegetation include reduced leaf and root growth, reduced plant height, and leaf and root necroses.

\subsection{METHODS FOR EVALUATING RADIATION AND CHEMICAL TOXICITY TO HUMANS}

\subsubsection{Radiation Toxicity}

The assessment of radiological human health risks in this BRA was limited to cancer induction. This approach is consistent with EPA guidance, which notes that cancer risk is generally the limiting effect for radionuclides and suggests that radiation carcinogenesis be used as the sole basis for assessing radiation-related human health risks (EPA 1989a). The EPA has developed guidance for radiological risk assessment that is consistent with the guidance for assessing chemical carcinogenic risks (EPA 1989a). Carcinogenic risks are calculated for the radionuclides of concern in a manner similar to existing methods for chemical carcinogens by using an age-averaged lifetime excess cancer incidence per unit intake (and per unit external exposure). The EPA has developed cancer incidence factors per unit intake that are synonymous with the slope factors developed for chemical carcinogens. The slope factors utilized in this assessment are presented in Table $4.1 .^{2}$

\subsubsection{Chemical Toxicity}

Toxicity values have been derived by the EPA for most of the chemical contaminants of human health concern. A toxicity value known as the reference dose (RfD) is used to evaluate the noncarcinogenic effects of chemicals. The chronic RfD is defined as "an estimate of a daily exposure level for the human population, including sensitive subpopulations, that is likely to be without an appreciable risk of deleterious effects during a lifetime" (EPA 1989a). To derive an RfD value (expressed in $\mathrm{mg} / \mathrm{kg}-\mathrm{d}$ ), EPA reviews all toxicity studies available for a given substance and a given

2 All tables in this chapter have been placed at the end of the text (after Section 4.3.2). 
route of exposure, determines a no-observed-adverse-effect level (NOAEL) or a lowest-observedadverse-effect level (LOAEL) from the study most relevant to humans (the critical study), and applies uncertainty factors to these values. The RfD can be compared with estimated exposure levels to evaluate the potential for deleterious effects. Currently available RfD values are specific to either the inhalation or ingestion route of exposure because the toxic mechanism and dose required for toxicity to occur can differ for those routes of exposure. Inhalation exposures are assessed with derived reference concentrations ( $\mathrm{RfCs}$ ), which are reported in milligrams per cubic meter $\left(\mathrm{mg} / \mathrm{m}^{3}\right.$ ). An RfC can be converted to the corresponding RfD (in $\mathrm{mg} / \mathrm{kg}$-d) by dividing by $70 \mathrm{~kg}$ (an assumed body weight) and multiplying by $20 \mathrm{~m}^{3} / \mathrm{d}$ (an assumed inhalation rate).

Carcinogenic risks from exposure to known and potential carcinogens were evaluated separately from noncarcinogenic risks because, hypothetically, any exposure to a carcinogen increases the risk of cancer by a finite amount. Therefore, the risk from exposure to a carcinogen at a given level can be derived, but an exposure level at which no carcinogenic effect is likely to occur (as for noncarcinogenic endpoints) cannot be defined. The EPA has defined two toxicity values for evaluating the potential carcinogenic effects of a given substance: the weight-of-evidence classification and the slope factor. For substances that have weight-of-evidence classifications of A (human carcinogen), B1 or B2 (probable human carcinogens), and sometimes $\mathrm{C}$ (possible human carcinogens), the EPA has calculated slope factors on the basis of data from dose-response studies. The slope factor is defined as a "plausible upper-bound estimate of the probability of a response (i.e., cancer) per unit intake of a chemical over a lifetime" (EPA 1989a). Generally, slope factors are derived by extrapolation from experimental high dose ranges to low doses, and they are not valid for the evaluation of high dose levels. Also, carcinogenic risks that have been calculated from slope factors are applicable to exposures that occur over a lifetime. When exposure durations are less than a lifetime, they must be converted to equivalent lifetime values. The RfD values and slope factors of COPCs are summarized in Tables 4.2 and 4.3, respectively. 
TABLE 4.1 Radionuclide Slope Factors for the Ingestion, Inhalation, and External Gamma Irradiation Pathways at the QROU

\begin{tabular}{llll}
\hline \multicolumn{1}{c}{ Radionuclide ${ }^{\mathrm{a}}$} & $\begin{array}{c}\text { Ingestion } \\
\text { (risk/pCi) }\end{array}$ & $\begin{array}{c}\text { Inhalation } \\
\text { (risk/pCi) }\end{array}$ & $\begin{array}{c}\text { External } \\
\text { Gamma Irradiation } \\
\text { (risk/yr per pCi/g soil) }\end{array}$ \\
\hline Lead-210+D & $1.01 \times 10^{-9}$ & $3.86 \times 10^{-9}$ & $1.45 \times 10^{-10}$ \\
Radium-226+D & $2.96 \times 10^{-10}$ & $2.75 \times 10^{-9}$ & $6.74 \times 10^{-6}$ \\
Radium-228+D & $2.48 \times 10^{-10}$ & $9.94 \times 10^{-10}$ & $3.28 \times 10^{-6}$ \\
Thorium-228+D & $2.31 \times 10^{-10}$ & $9.68 \times 10^{-8}$ & $6.20 \times 10^{-6}$ \\
Thorium-230 & $3.75 \times 10^{-11}$ & $1.72 \times 10^{-8}$ & $4.40 \times 10^{-11}$ \\
Thorium-232 & $3.28 \times 10^{-11}$ & $1.93 \times 10^{-8}$ & $1.97 \times 10^{-11}$ \\
Uranium-234 & $4.44 \times 10^{-11}$ & $1.40 \times 10^{-8}$ & $2.14 \times 10^{-11}$ \\
Uranium-235+D & $4.70 \times 10^{-11}$ & $1.30 \times 10^{-8}$ & $2.65 \times 10^{-7}$ \\
Uranium-238+D & $6.20 \times 10^{-11}$ & $1.24 \times 10^{-8}$ & $6.57 \times 10^{-8}$ \\
\hline
\end{tabular}

a Radionuclides marked with a " $+\mathrm{D}$ " indicate that the risks from associated short-lived radioactive decay products (i.e., those with half-lives less than or equal to 6 months) are also included.

Source: EPA (1995a). 


\begin{tabular}{|c|c|c|c|c|c|c|}
\hline Pathway/Parameter & $\begin{array}{l}\text { Chronic RfD } \\
\text { (mg/kg-d) }\end{array}$ & $\begin{array}{l}\text { Level of } \\
\text { Confidence }\end{array}$ & Critical Effect & \multicolumn{2}{|c|}{ RfD } & $\begin{array}{l}\text { Uncertainty } \\
\text { Factor } \\
\text { (UF) }\end{array}$ \\
\hline \multicolumn{7}{|l|}{ Ingestion } \\
\hline \multicolumn{7}{|l|}{ Metals } \\
\hline Arsenic & 0.0003 & Medium & $\begin{array}{l}\text { Hyperpigmentation, keritosis, and } \\
\text { possible vascular complications }\end{array}$ & Oral, human & IRIS & 3 \\
\hline Barium & 0.07 & Medium & Increased blood pressure & Water, human & IRIS & 3 \\
\hline Beryllium & 0.005 & Low & No adverse effects & Oral, rat & IRIS & 100 \\
\hline Cadmium & 0.0005 & High & Significant proteinuria & Water, human & IRIS & 10 \\
\hline Chromium VI & 0.005 & Low & No adverse effects & Water, rat & IRIS & 500 \\
\hline Lithium & 0.02 & Medium & Impaired renal function & Oral & - & 100 \\
\hline Manganese & 0.14 & Medium & Effects on central nervous system & Diet, human & IRIS & 1 \\
\hline $\begin{array}{l}\text { Mercury (as mercuric } \\
\text { chloride) }\end{array}$ & 0.0003 & High & Autoimmune effects & Diet, rat & IRIS & 1,000 \\
\hline Selenium & 0.005 & High & Nail and hair loss & Diet, human & IRIS & 3 \\
\hline Uranium (soluble salts) & 0.003 & Medium & Weight loss, moderate kidney toxicity & Oral, rabbit & IRIS & 1,000 \\
\hline Vanadium & 0.007 & $\mathrm{NA}^{\mathrm{b}}$ & No adverse effects & Water, rat & HEAST & 100 \\
\hline \multicolumn{7}{|l|}{ Organic compounds } \\
\hline $1,3,5-\mathrm{TNB}$ & 0.00005 & Low & Increased splenic weight & Oral, rat & IRIS & 10,000 \\
\hline 1,3-DNB & 0.0001 & Low & Increased splenic weight & Oral, rat & IRIS & 3,000 \\
\hline 2,4,6-TNT & 0.0005 & Medium & Liver effects & Oral, dog & IRIS & 1,000 \\
\hline 2,4-DNT & 0.002 & High & $\begin{array}{l}\text { Neurotoxicity; biliary tract hyperplasia; } \\
\text { Heinz bodies }\end{array}$ & Oral, dog & IRIS & 100 \\
\hline 2,6-DNT & 0.001 & NA & $\begin{array}{l}\text { Neurotoxicity; biliary tract hyperplasia; } \\
\text { Heinz bodies }\end{array}$ & Oral & HEAST & 3,000 \\
\hline
\end{tabular}




\section{TABLE 4.2 (Cont.)}

\begin{tabular}{|c|c|c|c|c|c|c|}
\hline \multirow[b]{2}{*}{ Pathway/Parameter } & \multirow{2}{*}{$\begin{array}{l}\text { Chronic RfD } \\
(\mathrm{mg} / \mathrm{kg}-\mathrm{d})\end{array}$} & \multirow{2}{*}{$\begin{array}{l}\text { Level of } \\
\text { Confidence }\end{array}$} & \multirow[b]{2}{*}{ Critical Effect } & \multicolumn{2}{|c|}{ RfD } & \multirow{2}{*}{$\begin{array}{c}\text { Uncertainty } \\
\text { Factor } \\
\text { (UF) }\end{array}$} \\
\hline & & & & Basis & Source $^{\mathrm{a}}$ & \\
\hline \multicolumn{7}{|l|}{ Ingestion (Cont.) } \\
\hline \multicolumn{7}{|c|}{ Organic compounds (cont.) } \\
\hline Nitrobenzene & 0.0005 & Low & $\begin{array}{l}\text { Hematological, adrenal, renal, and } \\
\text { hepatic lesions }\end{array}$ & $\begin{array}{l}\text { Inhalation; } \\
\text { rat, mouse }\end{array}$ & IRIS & 10,000 \\
\hline Aroclor 1254 & 0.00002 & Medium & Ocular exudate, inflamed glands & Diet, monkey & IRIS & 300 \\
\hline & & & & \multicolumn{2}{|c|}{ RfC } & Uncertainty \\
\hline Pathway/Parameter & $\begin{array}{c}\mathrm{RfC} \\
(\mathrm{mg} / \mathrm{kg}-\mathrm{d})\end{array}$ & $\begin{array}{l}\text { Level of } \\
\text { Confidence }\end{array}$ & Critical Effect & Basis & Source $^{\mathfrak{a}}$ & $\begin{array}{l}\text { Factor } \\
\text { (UF) }\end{array}$ \\
\hline \multirow{2}{*}{\multicolumn{7}{|c|}{$\begin{array}{l}\text { Inhalation } \\
\text { Metals }\end{array}$}} \\
\hline & & & & & & \\
\hline Manganese & 0.00005 & Medium & Neurobehavioral function impairment & $\begin{array}{l}\text { Occupational, } \\
\text { human }\end{array}$ & IRIS & 1000 \\
\hline Mercury & 0.0003 & Medium & Hand tremor; memory disturbance & $\begin{array}{l}\text { Occupational, } \\
\text { inhalation }\end{array}$ & IRIS & 30 \\
\hline
\end{tabular}

a Source: IRIS = Integrated Risk Information System database (EPA Office of Research and Development, accessed February 1997) (EPA 1997); HEAST $=$ Health Effects Assessment Summary Tables (EPA 1995a).

b NA = not available; a risk assessment for this substance is under review by an EPA work group. 
TABLE 4.3 Toxicity Values of COPCs for Ingestion and Inhalation: Potential Carcinogenic Effects

\begin{tabular}{|c|c|c|c|c|c|}
\hline \multirow[b]{2}{*}{ Pathway/Parameter } & \multirow{2}{*}{$\begin{array}{l}\text { Slope Factor } \\
{\left[(\mathrm{mg} / \mathrm{kg}-\mathrm{d})^{-1}\right]}\end{array}$} & \multirow[b]{2}{*}{ Weight of Evidence Classification } & \multirow[b]{2}{*}{ Type of Cancer } & \multicolumn{2}{|c|}{ Slope Factor } \\
\hline & & & & Basis & Source \\
\hline \multicolumn{6}{|l|}{ Ingestion } \\
\hline \multicolumn{6}{|l|}{ Metals } \\
\hline Arsenic & 1.5 & A: human carcinogen & Skin & Water, human & IRIS \\
\hline Beryllium & 4.3 & B2: probable human carcinogen & Total tumors & Water, rat & IRIS \\
\hline \multicolumn{6}{|l|}{ Organic compounds } \\
\hline $2,4,6-\mathrm{TNT}$ & 0.03 & C: possible human carcinogen & $\begin{array}{l}\text { Urinary bladder; transitional cell papilloma; } \\
\text { transitional squamous carcinoma }\end{array}$ & Diet, rat & IRIS \\
\hline 2,4-DNT & 0.68 & B2: probable human carcinogen & $\begin{array}{l}\text { Liver, mammary gland; adenocarcinomas/ } \\
\text { carcinomas }\end{array}$ & Water, rat & IRIS \\
\hline 2,6-DNT & 0.68 & B2: probable human carcinogen & $\begin{array}{l}\text { Liver, mammary gland; adenocarcinomas/ } \\
\text { carcinomas }\end{array}$ & Water, rat & IRIS \\
\hline PCBs & 2.0 & B2: probable human carcinogen & $\begin{array}{l}\text { Liver hepatocellular adenomas, carcinomas, } \\
\text { cholangiomas }\end{array}$ & Diet, rat & IRIS \\
\hline PAHs $^{b}$ & 7.3 & B2: probable human carcinogen & Forestomach; larynx; esophagus & Diet, mouse and rat & IRIS \\
\hline & & & & \multicolumn{2}{|c|}{ Slope Factor } \\
\hline Pathway/Parameter & $\begin{array}{l}\text { Unit Risk } \\
\left(\mu \mathrm{g} / \mathrm{m}^{3}\right)\end{array}$ & Weight of Evidence Classification & Type of Cancer & Basis & Source \\
\hline \multicolumn{6}{|l|}{ Inhalation } \\
\hline \multicolumn{6}{|l|}{ Metals } \\
\hline Arsenic & 0.0043 & A: human carcinogen & Lung & Occupational, human & IRIS \\
\hline Beryllium & 0.0024 & B2: probable human carcinogen & Lung & Occupational, human & IRIS \\
\hline Cadmium & 0.0018 & B1: probable human carcinogen & Lung, trachea; bronchus cancer deaths & Occupational, human & IRIS \\
\hline Chromium VI & 0.012 & A: human carcinogen & Lung & Occupational, human & IRIS \\
\hline
\end{tabular}

a Source: IRIS = Integrated Risk Information System database (EPA Office of Research and Development, accessed February 1997) (EPA 1997).

b Slope factor for benzo[a]pyrene used to quantify risk for all class B2 PAHs (i.e., benz[a]anthracene, benzo[b]fluoranthene, benzo[k]fluoranthene, dibenz[a,h]anthracene, indeno[1,2,3-cd]pyrene, and chrysene). 


\section{HUMAN HEALTH RISK CHARACTERIZATION}

\subsection{RISK CHARACTERIZATION METHODOLOGY}

Potential carcinogenic health risks resulting from exposure to radioactive and chemical contamination present in the quarry area were assessed in terms of the increased probability that an individual would develop cancer over a lifetime. The EPA has indicated that for known or suspected carcinogens, the acceptable exposure levels for members of the general public at sites on the National Priorities List (NPL) are generally concentration levels that represent an excess upperbound lifetime cancer risk to an individual of between $1 \times 10^{-6}$ and $1 \times 10^{-4}$ (EPA 1990). This range is referred to as the "acceptable risk range" in this BRA and is used as a point of reference for discussing the results of the carcinogenic risk assessment for the QROU.

Potential health effects other than cancer from exposure to chemical contaminants were also assessed. The quantitative measures of noncarcinogenic health effects are the hazard quotient and hazard index. The EPA has defined a hazard index of greater than 1 as the level of concern for noncarcinogenic health effects.

\subsubsection{Radiological Risks}

Exposures to ionizing radiation can result in cancer induction, serious genetic effects, and other detrimental health effects. The predominant health concern associated with the radioactive contaminants at the quarry area (which are primarily alpha-emitting radionuclides) is the induction of cancer. The radiological health risks evaluated in this BRA were limited to this concern. This approach is consistent with EPA guidance, which notes that, in general, the risk of cancer is liniting and may be used as the sole basis for assessing the radiation-related human health risks for a site contaminated with radionuclides (EPA 1989a).

For this assessment, slope factors were used to estimate the potential risk from exposure to radionuclides. Intakes were estimated for each exposure pathway (see Chapter 3). Radiological risks were calculated by multiplying the intakes by the appropriate slope factor given in Table 4.1. In addition, a radiological dose was calculated on the basis of measured exposure levels and a dose conversion factor (see Chapter 3 ). The dose was converted to carcinogenic risk by applying a risk factor of $6 \times 10^{-7} / \mathrm{mrem}$. This additional calculation was performed to verify the results of the external gamma risk calculated with the slope factor approach. Justification for this risk factor is provided in the baseline assessment for the chemical plant area (DOE 1992). 


\subsubsection{Chemical Risks and Hazard Quotients}

\subsubsection{Carcinogenic Risks}

The risk to an individual resulting from exposure to chemical carcinogens is expressed as the probability of a cancer occurring over a lifetime. To calculate the excess cancer risk, the daily intake averaged over a lifetime is multiplied by a chemical-specific slope factor. The EPA has derived slope factors for a number of carcinogens, and they represent the incremental lifetime cancer risk per milligram of carcinogen per kilogram of body weight, assuming that the exposure occurs over a lifetime of 70 years. The estimated daily intakes (averaged over a lifetime) resulting from exposure to the chemical carcinogens in residual soil and ponded water at the quarry proper, surface water and sediment at Femme Osage Slough, and groundwater are presented in Chapter 3; available slope factors are listed in Chapter 4.

\subsubsection{Hazard Quotients and Hazard Indices}

A hazard quotient provides a measure of the potential for adverse health effects other than cancer. For an individual contaminant, the daily intake averaged over the exposure period is divided by the reference dose, or RfD, to derive the hazard quotient. The RfD is the average daily dose that can be incurred without an appreciable risk of deleterious health effects during a lifetime. The EPA has derived RfDs for exposure periods of more than 7 years; only chronic RfDs were considered in this assessment.

For an individual contaminant, a hazard quotient of 1 or greater is considered to indicate a potential for adverse health effects. The individual hazard quotients for each contaminant are summed to determine a hazard index.

\subsection{HUMAN HEALTH RISK ESTIMATES}

\subsubsection{Quarry Proper}

The radiological carcinogenic health risks for a recreational visitor from exposure to residual soils at the quarry proper are presented in Table $5.1 .^{3}$ The total risks resulting from external irradiation, ingestion of soil, inhalation of airborne particulates, and dermal contact were estimated to be $1 \times 10^{-5}$ for soils and $3 \times 10^{-5}$ for fractures. The major contributor to the total risk was external

\footnotetext{
3 All tables in this chapter have been placed at the end of the text (after Section 5.3.4).
} 
gamma irradiation from radium-226 and radium-228. For comparison, the risk calculated by using the exposure rate measurement in the quarry proper $(17 \mu \mathrm{R} / \mathrm{h})$ from the pressurized ionization chamber was estimated to be $2 \times 10^{-5}$. This result is consistent with the risks calculated on the basis of soil concentrations.

The chemical carcinogenic risks for the recreational visitor who could be exposed to residual contamination present in the soil and fractures at the quarry proper were estimated to be within the acceptable risk range. The estimated risks are $1 \times 10^{-7}$ and $6 \times 10^{-8}$ for exposure to soil and fractures, respectively (Table 5.2). Systemic toxicity is not indicated, as evidenced by the low estimated hazard indices, 0.004 and 0.008 for soil and fractures, respectively.

\subsubsection{Femme Osage Slough}

The radiological and chemical carcinogenic health risks and hazard quotients estimated for a recreational visitor from exposures to surface water and sediment at Femme Osage Slough are presented in Table 5.3. The carcinogenic health risks and hazard quotients from ingestion of fish caught in the slough are presented in Table 5.4. The total radiological risk from all contaminated media is below EPA's acceptable risk range. For radionuclides, the primary source of risk is from ingestion of uranium in surface water. The radiological health risks for the recreational visitor exposed to contaminated surface water, sediment, and fish at the slough are $3 \times 10^{-7}, 3 \times 10^{-8}$, and $8 \times 10^{-9}$, respectively.

The chemical carcinogenic risks for the recreational visitor at Femme Osage Slough were estimated to be $9 \times 10^{-7}, 2 \times 10^{-7}$, and $3 \times 10^{-6}$ from exposure to surface water, sediment, and fish, respectively. These estimates are below or at the low end of the acceptable risk range. The estimated hazard indices for exposure to surface water, sediment, and fish are all less than 1 (i.e., 0.006 for surface water, 0.007 for sediment, and 0.03 for fish), indicating that noncarcinogenic effects are unlikely.

\subsubsection{Groundwater}

The radiological and chemical carcinogenic health risks for a hypothetical resident from exposure to groundwater are presented in Tables 5.5 and 5.6, respectively. The estimated hazard quotients are presented in Table 5.7 for metals and Table 5.8 for nitroaromatic compounds. Risks and hazard quotients were estimated for ingestion of and dermal contact with groundwater for: each monitoring well. Because there is no current or future receptor to groundwater underlying the quarry area, these estimates are provided for informational purposes only. 
The estimated radiological risk for a hypothetical resident from exposure to groundwater ranged from $1 \times 10^{-7}$ to $4 \times 10^{-3}$. The highest risks were calculated for MW-1004 and MW-1008. Wells with risks greater than $1 \times 10^{-4}$ are located north of the slough in the area directly south and southeast of the quarry. Estimated risks for wells located south of the slough were below $1 \times 10^{-5}$. For comparison, the risk estimated for background levels of uranium is $4 \times 10^{-6}$.

The estimated chemical carcinogenic risks to the hypothetical future resident were at or below a risk of $1 \times 10^{-4}$. The major contributor to risk was 2,6-DNT. Levels of 1,3,5-TNB also contributed to a hazard quotient greater than 1 in three wells located north of the slough. Hazard quotients greater than 1 were estimated for wells north of the slough due to high levels of uranium. A hazard quotient greater than 1 was also indicated for several wells due to low levels of thallium.

\subsubsection{Multiple Exposure Pathways}

A recreational visitor at the quarry area might be exposed to contaminants in several media at multiple locations via multiple pathways (e.g., the same individual could be exposed to residual contaminants at the quarry proper and to contaminated surface water, sediment, and fish at Femme Osage Slough). Potential exposures across multiple locations and pathways can be estimated by adding risk estimates for the reasonable maximum exposures for the individual locations, as presented in Sections 5.2.1 and 5.2.2. From this approach, a recreational visitor exposed to contaminants at the quarry proper and at Femme Osage Slough could incur a total radiological carcinogenic risk of approximately $3 \times 10^{-5}$. The total chemical carcinogenic risk and hazard index for this receptor were estimated to be $4 \times 10^{-6}$ and 0.05 , respectively.

\subsection{UNCERTAINTIES RELATED TO RISK ESTIMATES}

The evaluation of risks to human health presented in this BRA was by necessity based on a number of assumptions. In addition, many uncertainties are inherent in the risk assessment process. The rationale for major assumptions used in this assessment and associated uncertainties are discussed in Sections 5.3.1 through 5.3.4.

\subsubsection{Contaminants of Potential Concern}

The identification of COPCs for the human health evaluation relied on assessing information or data collected from characterization and monitoring activities performed for the QROU. Data used in the RI (MK-Ferguson Company and Jacobs Engineering Group 1997) to establish the nature and extent of contamination in the quarry area were considered to provide an adequate database for identifying COPCs with sufficient certainty. 
The screening process described in Chapter 2 was performed to screen out those constituents considered to be essential nutrients or those detected at very low frequencies and concentrations. A concentration/toxicity screen was not performed, so the number of contaminants carried through the risk assessment was not limited. Uncertainty related to identifying COPCs is considered low (see Section 2.2).

\subsubsection{Exposure Assessment}

The amount and type of data available and the ability to address fate and transport impacts over time affect the determination of representative exposure point concentrations. The quantity of data available has been determined to be sufficient for this risk assessment. Exposure point concentrations used to project current and future risks were based on current concentrations. This approach is considered to be conservative. With removal of the bulk waste (the main source of contamination) having been recently completed, it is expected that the concentrations of the COPCs will decrease with time.

Some uncertainty is associated with the assumptions used to identify exposure scenarios and intake parameters. Site-specific factors, including fate and transport determinations, were used to identify the potential receptors and to select the scenario assumptions, such as extent of exposure (exposure time, frequency, and duration). These assumptions incorporated information on current land use and reasonable projections of future land use that consider the time frame of the assessment. The uncertainty in the selected scenarios (i.e., recreational visitor at the quarry proper and at Femme Osage Slough) is low because federal and state ownership of surrounding land is expected to continue in the foreseeable future. The surrounding wildlife areas are the most heavily used in the state, and future plans include further expansion of the recreational use of the area. Therefore, a recreational visitor scenario was considered appropriate for both current and future conditions.

Exposure to contaminated groundwater was determined to be an incomplete pathway (see Chapter 3). Nevertheless, estimates providing upper-bound information on the potential risk from possible ingestion of and dermal contact with groundwater by a hypothetical resident are presented in Section 5.2.3. Currently, contact with groundwater within the quarry area itself does not exist, and future contact is considered unlikely on the basis of continued recreational land use of the area. Further, the low water yields determined in the area would not be expected to support any sustained use of the shallow groundwater, even for recreational purposes (e.g., a drinking water station). Finally, any future influence from the quarry area would not likely change conditions that now exist at the county well field. To date, concentrations of uranium (the primary COPC) have been observed to decrease significantly south of the slough and are not affecting the well field. This condition can be attributed to high sorption of uranium in the fine-grained alluvium north of the slough, high dilution in the coarse-grained alluvium south of the slough, and a natural redox front that causes precipitation of uranium compounds (see the RI [MK-Ferguson Company and Jacobs Engineering Group 1997] for further discussion). 
The approach used to calculate the dermal pathway tends to be conservative in that critical contaminant-specific factors such as absorption fractions and permeability coefficients are not available. Only dermal absorption of PCBs from soil could be directly quantified because an absorption fraction factor is available for this compound. As a result, bounding upper-limit risks and hazard indices were estimated for sediment and soil on the basis of absorption through the gut. Default values for permeability coefficients were used for surface water calculations. These results are intended to provide a means of comparing the significance of this pathway to that of other exposure pathways evaluated in this assessment.

Considerable information is available for the ingestion pathway with respect to reasonable assumptions for intake parameters (e.g., ingestion rate), so related uncertainty is expected to be low. To estimate the reasonable maximum exposures for the identified receptors, best professional judgment was used in defining the variables that determine the extent of exposure. Intake parameters used in the exposure assessment were derived from data in the literature, including values provided by the EPA (1989c, 1991, 1995b). Because each of these values generally represents the 95th percentile of the distribution for that parameter, combining them results in a value that represents an even higher percentile for the overall exposure. Thus, in some cases, the "reasonable" representative exposure may be somewhat overestimated.

\subsubsection{Toxicity Assessment}

Standard RfDs and slope factors established by the EPA were used to estimate potential noncarcinogenic and carcinogenic health effects from exposure to chemical contaminants at the QROU. Neither RfDs nor slope factors are currently available to evaluate the potential health effects of aluminum, cobalt, lead, molybdenum, silver, and strontium. Potential effects of lead were determined by using the Uptake Biokinetic Model provided by EPA. The results indicate that the levels of lead reported would not contribute to undesirable levels of lead in the blood of young children. Potential toxicity from aluminum, cobalt, molybdenum, silver, and strontium is likely to be low and is not expected to alter the overall risk conclusions presented in this report.

\subsubsection{Risk Characterization}

The radiological and chemical risk assessments have been presented separately because the methodologies for estimating the carcinogenic risks from exposures to radionuclides and chemicals differ considerably. However, the total carcinogenic risk to an individual is that resulting from exposure to both the radiological and chemical risks, assuming that carcinogenic effects are neither antagonistic nor synergistic. 
TABLE 5.1 Estimated Radiological Carcinogenic Risks for a Future Recreational Visitor at the Quarry Proper

\begin{tabular}{|c|c|c|c|c|c|c|}
\hline \multirow[b]{2}{*}{$\begin{array}{c}\text { Exposure } \\
\text { Unit }\end{array}$} & \multirow[b]{2}{*}{ Radionuclide $^{\mathrm{a}}$} & \multicolumn{5}{|c|}{ Radiological Carcinogenic Risk } \\
\hline & & External $^{\mathrm{b}}$ & Ingestion $^{\mathrm{c}}$ & Dermal & Inhalation & Total \\
\hline \multirow[t]{6}{*}{ Soil } & Radium-226 & $6 \times 10^{-6}$ & $7 \times 10^{-8}$ & $3 \times 10^{-8}$ & $1 \times 10^{-11}$ & $6 \times 10^{-6}$ \\
\hline & Radium-228 & $9 \times 10^{-6}$ & $1 \times 10^{-7}$ & $2 \times 10^{-8}$ & $4 \times 10^{-10}$ & $9 \times 10^{-6}$ \\
\hline & Thorium-230 & $7 \times 10^{-10}$ & $2 \times 10^{-7}$ & $4 \times 10^{-11}$ & $1 \times 10^{-9}$ & $2 \times 10^{-7}$ \\
\hline & Thorium-232 & $1 \times 10^{-11}$ & $5 \times 10^{-9}$ & $1 \times 10^{-12}$ & $4 \times 10^{-11}$ & $5 \times 10^{-9}$ \\
\hline & Uranium-238 & $1 \times 10^{-7}$ & $4 \times 10^{-8}$ & $1 \times 10^{-10}$ & $2 \times 10^{-10}$ & $1 \times 10^{-7}$ \\
\hline & Total & $1 \times 10^{-5}$ & $4 \times 10^{-7}$ & $1 \times 10^{-7}$ & $2 \times 10^{-9}$ & $1 \times 10^{-5}$ \\
\hline \multirow[t]{6}{*}{ Fractures } & Radium-226 & $1 \times 10^{-5}$ & $1 \times 10^{-7}$ & $\mathrm{NA}^{\mathrm{d}}$ & $2 \times 10^{-11}$ & $1 \times 10^{-5}$ \\
\hline & Radium-228 & $2 \times 10^{-5}$ & $2 \times 10^{-7}$ & NA & $7 \times 10^{-10}$ & $2 \times 10^{-5}$ \\
\hline & Thorium-230 & $1 \times 10^{-9}$ & $2 \times 10^{-7}$ & NA & $2 \times 10^{-9}$ & $2 \times 10^{-7}$ \\
\hline & Thorium-232 & $5 \times 10^{-11}$ & $2 \times 10^{-8}$ & NA & $2 \times 10^{-10}$ & $2 \times 10^{-8}$ \\
\hline & Uranium-238 & $4 \times 10^{-7}$ & $2 \times 10^{-7}$ & NA & $7 \times 10^{-10}$ & $6 \times 10^{-7}$ \\
\hline & Total & $3 \times 10^{-5}$ & $7 \times 10^{-7}$ & NA & $4 \times 10^{-9}$ & $3 \times 10^{-5}$ \\
\hline
\end{tabular}

a Estimated risks for radium-226 include the contribution from lead-210; risks for radium-228 include the contribution from thorium-228; and risks for uranium-238 include the contribution from uranium-234.

b The estimated risk from external radiation calculated on the basis of exposure rate measurements in the quarry proper is $2 \times 10^{-5}$.

c The risk from ingestion of water from the quarry pond is estimated to be $3 \times 10^{-6}$, primarily from uranium.

d NA = not applicable; the dermal pathway was not considered for quarry fractures. 


\section{TABLE 5.2 Chemical Hazard Index and Carcinogenic Risks for a Future Recreational Visitor at the Quarry Proper}

\begin{tabular}{|c|c|c|c|c|c|c|c|c|c|c|}
\hline \multirow[b]{3}{*}{ Contaminant } & \multicolumn{6}{|c|}{ Soil } & \multicolumn{4}{|c|}{ Fractures $^{\mathrm{a}}$} \\
\hline & \multicolumn{3}{|c|}{ Hazard Quotient } & \multicolumn{3}{|c|}{$\begin{array}{c}\text { Lifetime } \\
\text { Carcinogenic Risk }\end{array}$} & \multicolumn{2}{|c|}{ Hazard Quotient } & \multicolumn{2}{|c|}{$\begin{array}{c}\text { Lifetime } \\
\text { Carcinogenic Risk }\end{array}$} \\
\hline & Ingestion & Dermal & Inhalation & Ingestion & Dermal & Inhalation & Ingestion & Inhalation & Ingestion & Inhalation \\
\hline \multicolumn{11}{|l|}{ Metals } \\
\hline Selenium & $<0.0001$ & $<0.0001$ & $\mathrm{NA}^{\mathrm{b}}$ & NA & NA & NA & 0.0004 & NA & NA & NA \\
\hline Silver & $<0.0001$ & $<0.0001$ & NA & NA & $\mathrm{NA}$ & NA & 0.0002 & NA & NA & NA \\
\hline Uranium & 0.0005 & $<0.0001$ & NA & NA & NA & NA & 0.002 & NA & NA & NA \\
\hline Zinc & $<0.0001$ & $<0.0001$ & NA & NA & NA & NA & $<0.0001$ & NA & NA & NA \\
\hline \multicolumn{11}{|c|}{ Organic compounds } \\
\hline $1,3,5-\mathrm{TNB}$ & 0.0007 & 0.0002 & NA & NA & NA & NA & 0.002 & NA & $\mathrm{NA}$ & NA \\
\hline 1,3-DNB & $<0.0001$ & $<0.0001$ & NA & NA & NA & NA & $--^{b}$ & NA & - & NA \\
\hline $2,4,6-\mathrm{TNT}$ & $<0.0001$ & $<0.0001$ & NA & $3 \times 10^{-10}$ & $5 \times 10^{-14}$ & NA & $<0.0001$ & NA & $4 \times 10^{-10}$ & NA \\
\hline 2,4-DNT & $<0.0001$ & $<0.0001$ & NA & $2 \times 10^{-9}$ & $4 \times 10^{-13}$ & NA & $<0.0001$ & NA & $8 \times 10^{-9}$ & $\mathrm{NA}$ \\
\hline 2,6-DNT & NA & NA & NA & $4 \times 10^{-10}$ & $4 \times 10^{-13}$ & NA & NA & NA & $2 \times 10^{-10}$ & NA \\
\hline Nitrobenzene & - & - & NA & NA & NA & NA & $<0.0001$ & NA & NA & NA \\
\hline PCBs & 0.003 & 0.0007 & $<0.0001$ & $9 \times 10^{-8}$ & $1 \times 10^{-8}$ & $1 \times 10^{-12}$ & 0.003 & $<0.0001$ & $5 \times 10^{-8}$ & $7 \times 10^{-13}$ \\
\hline PAHs & NA & $\mathrm{NA}$ & NA & $3 \times 10^{-8}$ & $6 \times 10^{-10}$ & $3 \times 10^{-13}$ & $\mathrm{NA}$ & NA & NA & $\mathrm{NA}$ \\
\hline Total $^{\mathrm{c}}$ & 0.004 & 0.0009 & $<0.0001$ & $1 \times 10^{-7}$ & $1 \times 10^{-8}$ & $1 \times 10^{-12}$ & 0.008 & $<0.0001$ & $6 \times 10^{-8}$ & $7 \times 10^{-13}$ \\
\hline
\end{tabular}

a Potential for dermal contact with contaminants in the fractures was considered unlikely and therefore not calculated.

b $\mathrm{NA}=$ not applicable; a verified RfD or slope factor is not available for calculation. A hyphen (-) indicates that the contaminant was not detected.

c Sum of hazard quotients equals hazard index. Chemical and radiological carcinogenic risks are not summed because of methodological differences. 
TABLE 5.3 Estimated Hazard Quotients and Carcinogenic Risks for a Recreational Visitor Exposed to Surface Water and Sediments at Femme Osage Slough

\begin{tabular}{|c|c|c|c|c|c|c|c|c|c|c|}
\hline \multirow[b]{3}{*}{ Contaminant } & \multicolumn{4}{|c|}{ Surface Water ${ }^{a}$} & \multicolumn{6}{|c|}{ Sediments ${ }^{a}$} \\
\hline & \multicolumn{2}{|c|}{ Hazard Quotient } & \multicolumn{2}{|c|}{$\begin{array}{c}\text { Lifetime } \\
\text { Carcinogenic Risk } \\
\end{array}$} & \multicolumn{3}{|c|}{ Hazard Quotient } & \multicolumn{3}{|c|}{ Lifetime Carcinogenic Risk } \\
\hline & Ingestion & Dermal & Ingestion & Dermal & Ingestion & Dermal & Inhalation & Ingestion & Dermal & Inhalation \\
\hline \multicolumn{11}{|l|}{ Radionuclides } \\
\hline Uranium, total & NA & NA & $3 \times 10^{-7}$ & $7 \times 10^{-9}$ & NA & NA & NA & $3 \times 10^{-8}$ & $1 \times 10^{-10}$ & $1 \times 10^{-10}$ \\
\hline \multicolumn{11}{|l|}{ Chemicals } \\
\hline \multicolumn{11}{|l|}{ Metals } \\
\hline Antimony & $*$ & * & * & * & 0.004 & 0.001 & NA & NA & NA & NA \\
\hline Arsenic & 0.002 & $<0.0001$ & $9 \times 10^{-7}$ & $2 \times 10^{-8}$ & $*$ & $*$ & $*$ & $*$ & $*$ & $*$ \\
\hline Beryllium & $*$ & $*$ & $*$ & $*$ & $<0.0001$ & $<0.0001$ & $\mathrm{NA}$ & $2 \times 10^{-7}$ & $2 \times 10^{-4}$ & $2 \times 10^{-15}$ \\
\hline Cadmium & $*$ & * & * & * & 0.0003 & $<0.0001$ & $\mathrm{NA}$ & NA & NA & $2 \times 10^{-15}$ \\
\hline Chromium & $*$ & $*$ & $*$ & * & 0.0004 & $<0.0001$ & NA & NA & NA & $1 \times 10^{-13}$ \\
\hline Copper & $<0.0001$ & $<0.0001$ & NA & NA & $<0.0001$ & $<0.0001$ & NA & $\mathrm{NA}$ & NA & NA \\
\hline Manganese & $*$ & * & $*$ & $*$ & 0.0006 & $<0.0001$ & $<0.0001$ & NA & NA & NA \\
\hline Mercury & $*$ & $*$ & $*$ & $*$ & $<0.0001$ & $<0.0001$ & $<0.0001$ & NA & NA & NA \\
\hline Molybdenum & * & $*$ & $*$ & $*$ & $<0.0001$ & $<0.0001$ & NA & NA & NA & NA \\
\hline Nickel & 0.0001 & $<0.0001$ & $\mathrm{NA}$ & $\mathrm{NA}$ & $<0.0001$ & $<0.0001$ & NA & NA & NA & NA \\
\hline Selenium & $*$ & $*$ & $*$ & $*$ & $<0.0001$ & $<0.0001$ & $\mathrm{NA}$ & NA & $\mathrm{NA}$ & NA \\
\hline Silver & 0.0004 & $<0.0001$ & NA & NA & $<0.0001$ & $<0.0001$ & NA & NA & NA & $\mathrm{NA}$ \\
\hline Strontium & $<0.0001$ & $<0.0001$ & $\mathrm{NA}$ & NA & $<0.0001$ & $<0.0001$ & $\mathrm{NA}$ & $\mathrm{NA}$ & $\mathrm{NA}$ & $\mathrm{NA}$ \\
\hline Uranium & 0.004 & $<0.0001$ & NA & NA & 0.0004 & $<0.0001$ & NA & NA & NA & NA \\
\hline Vanadium & * & $*$ & * & $*$ & 0.0005 & $<0.0001$ & $\mathrm{NA}$ & $\mathrm{NA}$ & NA & NA \\
\hline Zinc & $<0.0001$ & $<0.0001$ & NA & NA & $<0.0001$ & $<0.0001$ & $\mathrm{NA}$ & NA & NA & NA \\
\hline \multicolumn{11}{|c|}{ Nitroaromatic compounds } \\
\hline 1,3,5-TNB & $<0.0001$ & $<0.0001$ & NA & NA & $<0.0001$ & $<0.0001$ & NA & NA & NA & NA \\
\hline 1,3 -DNB & - & - & NA & NA & $<0.0001$ & $<0.0001$ & $\mathrm{NA}$ & $\mathrm{NA}$ & NA & NA \\
\hline $2,4,6-\mathrm{TNT}$ & $<0.0001$ & $<0,0001$ & $1 \times 10^{-10}$ & $3 \times 10^{-12}$ & $<0.0001$ & $<0.0001$ & NA & $1 \times 10^{-11}$ & $8 \times 10^{-11}$ & NA \\
\hline 2,4-DNT & $<0.0001$ & $<0.0001$ & $1 \times 10^{-9}$ & $2 \times 10^{-11}$ & $<0.0001$ & $<0.0001$ & $\mathrm{NA}$ & $2 \times 10^{-10}$ & $5 \times 10^{-11}$ & NA \\
\hline 2,6-DNT & $<0.0001$ & $<0.0001$ & $1 \times 10^{-9}$ & $2 \times 10^{-11}$ & $<0.0001$ & $<0.0001$ & $\mathrm{NA}$ & $5 \times 10^{-10}$ & $2 \times 10^{-9}$ & NA \\
\hline NB & - & - & $\mathrm{NA}$ & NA & $<0.0001$ & $<0.0001$ & NA & NA & NA & $\mathrm{NA}$ \\
\hline Total chemicals ${ }^{\mathrm{b}}$ & 0.006 & $<0.0001$ & $9 \times 10^{-7}$ & $2 \times 10^{-8}$ & 0.006 & 0.001 & $<0.0001$ & $2 \times 10^{-7}$ & $4 \times 10^{-9}$ & $1 \times 10^{-13}$ \\
\hline
\end{tabular}

a NA = not applicable; a hyphen (-) indicates that the parameter was not detected; an asterisk $\left(^{*}\right)$ indicates that the parameter is not a contaminant of potential concern for that medium.

b Sum of hazard quotients equals hazard index. Chemical and radiological carcinogenic risks are not summed because of methodological differences. 
TABLE 5.4 Estimated Hazard Quotients and Carcinogenic Risks for Ingestion of Fish from Femme Osage Slough

\begin{tabular}{|c|c|c|}
\hline Contaminants & $\begin{array}{l}\text { Hazard } \\
\text { Quotient }\end{array}$ & $\begin{array}{c}\text { Lifetime } \\
\text { Carcinogenic Risk }\end{array}$ \\
\hline \multicolumn{3}{|l|}{ Radionuclides } \\
\hline Uranium, total & $\mathrm{NA}^{\mathrm{a}}$ & $8 \times 10^{-9}$ \\
\hline \multicolumn{3}{|l|}{ Chemicals } \\
\hline \multicolumn{3}{|l|}{ Metals } \\
\hline Arsenic & 0.01 & $3 \times 10^{-6}$ \\
\hline Lead & NA & NA \\
\hline Mercury & 0.02 & NA \\
\hline Uranium & 0.0001 & NA \\
\hline Total chemicals ${ }^{\mathrm{b}}$ & 0.03 & $3 \times 10^{-6}$ \\
\hline
\end{tabular}

a $\mathrm{NA}=$ not applicable.

b Radiological and chemical risks are not summed because of methodological differences. 
TABLE 5.5 Estimated Radiological Carcinogenic Risks for a Hypothetical Future Resident

\begin{tabular}{|c|c|c|c|}
\hline Well ID & Uranium Risk & Well ID & Uranium Risk \\
\hline North of Slough & \multicolumn{3}{|c|}{ South of Slough } \\
\hline MW-1002 & $4 \times 10^{-6}$ & MW-1010 & $5 \times 10^{-7}$ \\
\hline MW-1004 & $4 \times 10^{-3}$ & MW-1011 & $6 \times 10^{-6}$ \\
\hline MW-1005 & $2 \times 10^{-3}$ & MW-1017 & $2 \times 10^{-6}$ \\
\hline MW-1006 & $3 \times 10^{-3}$ & MW-1018 & $2 \times 10^{-6}$ \\
\hline MW-1007 & $7 \times 10^{-5}$ & MW-1019 & $6 \times 10^{-6}$ \\
\hline MW-1008 & $4 \times 10^{-3}$ & MW-1020 & $5 \times 10^{-6}$ \\
\hline MW-1009 & $2 \times 10^{-5}$ & MW-1021 & $1 \times 10^{-6}$ \\
\hline MW-1013 & $1 \times 10^{-3}$ & MW-1022 & $1 \times 10^{-6}$ \\
\hline MW-1014 & $1 \times 10^{-3}$ & MW-1023 & $2 \times 10^{-6}$ \\
\hline MW-1015 & $4 \times 10^{-4}$ & MW-1033 & $7 \times 10^{-6}$ \\
\hline MW-1016 & $2 \times 10^{-4}$ & MW-1044 & $3 \times 10^{-7}$ \\
\hline MW-1026 & $1 \times 10^{-7}$ & RMW-1 & $2 \times 10^{-6}$ \\
\hline MW-1027 & $5 \times 10^{-4}$ & RMW-2 & $7 \times 10^{-6}$ \\
\hline MW-1028 & $3 \times 10^{-6}$ & RMW-3 & $1 \times 10^{-6}$ \\
\hline MW-1029 & $2 \times 10^{-6}$ & RMW-4 & $3 \times 10^{-6}$ \\
\hline MW-1030 & $7 \times 10^{-5}$ & & \\
\hline MW-1031 & $2 \times 10^{-4}$ & & \\
\hline MW-1032 & $1 \times 10^{-3}$ & & \\
\hline MW-1035 & $6 \times 10^{-7}$ & & \\
\hline MW-1036 & $8 \times 10^{-6}$ & & \\
\hline MW-1037 & $2 \times 10^{-6}$ & & \\
\hline MW-1038 & $4 \times 10^{-6}$ & & \\
\hline MW-1039 & $7 \times 10^{-7}$ & & \\
\hline MW-1040 & $7 \times 10^{-6}$ & & \\
\hline MW-1041 & $5 \times 10^{-6}$ & & \\
\hline MW-1045 & $6 \times 10^{-6}$ & & \\
\hline MW-1046 & $3 \times 10^{-5}$ & & \\
\hline MW-1047 & $3 \times 10^{-6}$ & & \\
\hline MW-1048 & $2 \times 10^{-4}$ & & \\
\hline MW-1049 & $6 \times 10^{-7}$ & & \\
\hline
\end{tabular}


TABLE 5.6 Estimated Chemical Carcinogenic Risks for a Hypothetical Future Resident ${ }^{\mathrm{a}}$

\begin{tabular}{|c|c|c|c|c|}
\hline \multirow[b]{2}{*}{ Well ID } & \multicolumn{4}{|c|}{ Estimated Risk } \\
\hline & $2,4,6-\mathrm{TNT}$ & 2,4-DNT & 2,6-DNT & Total \\
\hline MW-1002 & $1 \times 10^{-5}$ & $1 \times 10^{-6}$ & $1 \times 10^{-4}$ & $1 \times 10^{-4}$ \\
\hline MW-1004 & $3 \times 10^{-6}$ & $6 \times 10^{-6}$ & $7 \times 10^{-6}$ & $2 \times 10^{-5}$ \\
\hline MW-1005 & $-b$ & - & - & - \\
\hline MW-1006 & $4 \times 10^{-6}$ & $4 \times 10^{-6}$ & $2 \times 10^{-5}$ & $3 \times 10^{-5}$ \\
\hline MW-1007 & $3 \times 10^{-8}$ & - & $2 \times 10^{-7}$ & $2 \times 10^{-7}$ \\
\hline MW-1008 & $7 \times 10^{-8}$ & - & $3 \times 10^{-7}$ & $4 \times 10^{-7}$ \\
\hline MW-1009 & - & - & - & - \\
\hline MW-1013 & - & $3 \times 10^{-7}$ & $1 \times 10^{-7}$ & $4 \times 10^{-7}$ \\
\hline MW-1014 & - & - & - & - \\
\hline MW-1015 & $1 \times 10^{-6}$ & $2 \times 10^{-7}$ & $2 \times 10^{-6}$ & $3 \times 10^{-6}$ \\
\hline MW-1016 & $1 \times 10^{-7}$ & - & $4 \times 10^{-7}$ & $5 \times 10^{-7}$ \\
\hline MW-1026 & - & - & - & - \\
\hline MW-1027 & $4 \times 10^{-7}$ & $3 \times 10^{-5}$ & $2 \times 10^{-5}$ & $5 \times 10^{-5}$ \\
\hline MW-1028 & - & - & - & - \\
\hline$M W-1029$ & - & - & $9 \times 10^{-8}$ & $9 \times 10^{-8}$ \\
\hline MW-1030 & $8 \times 10^{-9}$ & $2 \times 10^{-7}$ & $3 \times 10^{-7}$ & $5 \times 10^{-7}$ \\
\hline$M W-1031$ & - & - & - & - \\
\hline MW-1032 & $2 \times 10^{-7}$ & $2 \times 10^{-6}$ & $6 \times 10^{-7}$ & $3 \times 10^{-6}$ \\
\hline MW-1035 & - & - & - & - \\
\hline MW-1036 & - & - & - & - \\
\hline MW-1037 & - & $1 \times 10^{-7}$ & - & $1 \times 10^{-7}$ \\
\hline MW-1038 & - & - & - & - \\
\hline MW-1039 & - & - & - & - \\
\hline MW-1040 & - & - & - & - \\
\hline MW-1041 & - & - & - & - \\
\hline MW-1045 & - & - & - & - \\
\hline MW-1046 & - & - & - & - \\
\hline MW-1047 & - & - & - & - \\
\hline MW-1048 & - & - & - & - \\
\hline MW-1049 & - & - & - & - \\
\hline
\end{tabular}

a Nitroaromatic compounds were not detected in wells located south of the slough.

b A hyphen (-) indicates that the compound was not detected. 
TABLE 5.7 Estimated Hazard Quotients for Metals for a Hypothetical Future Resident

\begin{tabular}{|c|c|c|c|c|c|c|}
\hline \multirow[b]{2}{*}{ Well ID } & \multicolumn{6}{|c|}{ Estimated Hazard Quotient } \\
\hline & Barium & Cadmium & Chromium & Copper & Manganese & Mercury \\
\hline \multicolumn{7}{|c|}{ North of Slough } \\
\hline MW-1002 & 0.045 & $-^{\mathrm{a}}$ & 0.022 & - & 0.065 & - \\
\hline MW-1004 & 0.031 & - & - & 0.0076 & 0.067 & - \\
\hline MW-1005 & - & - & - & - & - & - \\
\hline MW-1006 & 0.030 & 0.017 & 0.015 & 0.019 & 0.43 & - \\
\hline MW-1007 & 0.13 & - & - & 0.019 & 0.77 & - \\
\hline MW-1008 & 0.032 & - & - & 0.024 & 0.70 & - \\
\hline MW-1009 & 0.18 & - & - & 0.012 & 0.97 & - \\
\hline MW-1013 & 0.076 & - & - & - & 0.12 & - \\
\hline MW-1014 & 0.053 & - & - & 0.0036 & 0.033 & - \\
\hline MW-1015 & 0.11 & - & - & 0.012 & 0.19 & - \\
\hline MW-1016 & 0.066 & - & 0.035 & 0.013 & 0.043 & - \\
\hline MW-1026 & 0.16 & - & - & 0.013 & 0.38 & - \\
\hline MW-1027 & 0.047 & - & 0.029 & 0.013 & 0.011 & - \\
\hline MW-1028 & 0.14 & - & - & - & 0.16 & 0.015 \\
\hline MW-1029 & 0.044 & - & 0.040 & 0.020 & 0.019 & - \\
\hline$M W-1030$ & 0.070 & 0.019 & 0.51 & 0.018 & 0.23 & - \\
\hline MW-1031 & 0.041 & - & - & - & 0.0031 & - \\
\hline MW-1032 & 0.037 & - & - & 0.0051 & 0.022 & - \\
\hline MW-1035 & 0.12 & 0.0031 & 0.059 & - & 0.14 & - \\
\hline MW-1036 & 0.096 & 0.0014 & 0.051 & 0.0043 & 0.13 & - \\
\hline MW-1037 & 0.16 & 0.0019 & 0.11 & 0.0081 & 0.34 & - \\
\hline MW-1038 & 0.15 & - & 0.053 & 0.010 & 0.080 & - \\
\hline MW-1039 & 0.21 & - & 0.029 & 0.0064 & 0.51 & - \\
\hline MW-1040 & 0.15 & 0.012 & 0.0098 & 0.018 & 0.24 & - \\
\hline MW-1041 & 0.17 & 0.015 & 0.052 & - & 0.21 & - \\
\hline MW-1045 & 0.13 & - & 0.048 & 0.027 & 0.25 & - \\
\hline MW-1046 & 0.087 & - & 0.061 & 0.028 & 0.038 & - \\
\hline MW-1047 & 0.24 & - & 0.076 & 0.026 & 0.091 & - \\
\hline MW-1048 & 0.18 & - & 0.059 & 0.086 & 0.11 & - \\
\hline MW-1049 & 0.48 & - & 0.046 & 0.016 & 0.19 & - \\
\hline
\end{tabular}


TABLE 5.7 (Cont.)

\begin{tabular}{|c|c|c|c|c|c|c|}
\hline \multirow[b]{2}{*}{ Well ID } & \multicolumn{6}{|c|}{ Estimated Hazard Quotient } \\
\hline & Nickel & Thallium & Uranium & Vanadium & Zinc & Total \\
\hline \multicolumn{7}{|c|}{ North of Slough (cont.) } \\
\hline$M W-1002$ & 0.024 & - & 0.049 & - & 0.00077 & 0.15 \\
\hline MW-1004 & 0.033 & 1.3 & 48 & - & 0.0013 & 49 \\
\hline MW-1005 & - & - & 30 & - & - & 30 \\
\hline MW-1006 & - & 1.9 & 42 & 0.98 & 0.0019 & 45 \\
\hline MW-1007 & - & 2.8 & 0.83 & 0.11 & 0.0021 & 4.6 \\
\hline MW-1008 & - & - & 47 & 0.13 & 0.0027 & 48 \\
\hline MW-1009 & - & 2.4 & 0.21 & 0.072 & 0.0020 & 3.8 \\
\hline MW-1013 & - & - & 12 & - & 0.0013 & 12 \\
\hline MW-1014 & - & - & 15 & - & 0.00089 & 15 \\
\hline MW-1015 & - & 1.1 & 4.6 & 0.053 & 0.0061 & 6.1 \\
\hline MW-1016 & - & - & 2.8 & 0.062 & 0.0063 & 3.0 \\
\hline MW-1026 & 0.021 & - & 0.0014 & 0.053 & 0.0011 & 0.63 \\
\hline MW-1027 & - & - & 5.8 & 0.057 & 0.0066 & 5.9 \\
\hline MW-1028 & - & 1.9 & 0.042 & - & 0.00091 & 2.2 \\
\hline MW-1029 & 0.018 & 0.93 & 0.029 & 0.048 & 0.0022 & 1.1 \\
\hline MW-1030 & 0.083 & 1.6 & 0.87 & 0.065 & 0.011 & 3.5 \\
\hline MW-1031 & - & 1.7 & 2.3 & - & 0.00061 & 4.0 \\
\hline MW-1032 & 0.024 & - & 14 & - & 0.00066 & 14 \\
\hline MW-1035 & - & - & 0.0076 & 0.011 & 0.00084 & 0.33 \\
\hline MW-1036 & 0.0057 & - & 0.11 & 0.014 & 0.0014 & 0.40 \\
\hline MW-1037 & - & - & 0.028 & 0.027 & 0.0033 & 0.66 \\
\hline MW-1038 & - & - & 0.053 & 0.033 & 0.0038 & 0.38 \\
\hline MW-1039 & - & - & 0.0084 & 0.012 & 0.0035 & 0.76 \\
\hline MW-1040 & 0.029 & 1.5 & 0.091 & 0.13 & 0.0076 & 2.2 \\
\hline MW-1041 & 0.010 & - & 0.061 & - & 0.0016 & 0.44 \\
\hline MW-1045 & 0.051 & - & 0.079 & 0.16 & 0.0049 & 0.75 \\
\hline MW-1046 & 0.026 & - & 0.38 & 0.072 & 0.0055 & 0.69 \\
\hline MW-1047 & 0.020 & - & 0.041 & 0.073 & 0.0089 & 0.53 \\
\hline MW-1048 & - & - & 2.7 & 0.26 & 0.015 & 3.4 \\
\hline MW-1049 & 0.018 & - & 0.0068 & 0.052 & 0.0042 & 0.80 \\
\hline
\end{tabular}


TABLE 5.7 (Cont.)

Estimated Hazard Quotient

\begin{tabular}{|c|c|c|c|c|c|c|}
\hline \multirow[b]{2}{*}{ Well ID } & \multicolumn{6}{|c|}{ Estimated Hazard Quotient } \\
\hline & Barium & Cadmium & Chromium & Copper & Manganese & Mercury \\
\hline \multicolumn{7}{|c|}{ South of Slough } \\
\hline MW-1010 & 0.14 & - & - & 0.010 & 0.20 & - \\
\hline MW-1011 & 0.040 & - & - & 0.029 & 0.0048 & - \\
\hline MW-1017 & 0.35 & - & 0.048 & 0.0099 & 0.077 & - \\
\hline MW-1018 & 0.21 & - & 0.035 & 0.0062 & 0.16 & - \\
\hline MW-1019 & 0.26 & - & 0.037 & 0.0068 & 0.37 & - \\
\hline MW-1020 & 0.14 & - & - & 0.011 & 0.47 & - \\
\hline MW-1021 & 0.28 & - & 0.021 & 0.0066 & 0.099 & - \\
\hline MW-1022 & 0.19 & - & - & 0.0040 & 0.11 & - \\
\hline MW-1023 & 0.23 & - & 0.098 & 0.021 & 0.15 & - \\
\hline MW-1033 & 0.30 & - & 0.028 & 0.0032 & 0.25 & - \\
\hline MW-1044 & 0.24 & - & 0.060 & 0.025 & 0.18 & - \\
\hline RMW-1 & 0.24 & - & 0.054 & 0.0019 & 0.56 & - \\
\hline RMW-2 & 0.15 & - & 0.044 & - & 0.17 & - \\
\hline RMW-3 & 0.18 & - & - & - & - & - \\
\hline \multirow[t]{2}{*}{ RMW-4 } & 0.10 & - & - & - & - & - \\
\hline & \multicolumn{6}{|c|}{ Estimated Hazard Quotient } \\
\hline Well ID & Nickel & Thallium & Uranium & Vanadium & Zinc & Total \\
\hline \multicolumn{7}{|c|}{ South of Slough (cont.) } \\
\hline MW-1010 & - & - & 0.0060 & 0.030 & 0.00075 & 0.38 \\
\hline MW-1011 & - & - & 0.076 & 0.047 & - & 0.19 \\
\hline MW-1017 & 0.020 & 1.6 & 0.020 & 0.052 & 0.0061 & 2.1 \\
\hline MW-1018 & 0.029 & 1.7 & 0.025 & 0.038 & 0.0043 & 2.2 \\
\hline MW-1019 & - & - & 0.069 & 0.036 & 0.0039 & 0.73 \\
\hline MW-1020 & 0.015 & 1.2 & 0.061 & 0.053 & 0.0010 & 1.9 \\
\hline MW-1021 & 0.016 & 1.1 & 0.012 & 0.031 & 0.0034 & 1.5 \\
\hline MW-1022 & 0.019 & - & 0.012 & 0.015 & 0.0028 & 0.32 \\
\hline$M W-1023$ & 0.037 & 1.4 & 0.025 & 0.12 & 0.010 & 2.0 \\
\hline MW-1033 & 0.018 & - & 0.051 & - & 0.0013 & 0.60 \\
\hline MW-1044 & 0.013 & - & 0.0042 & 0.095 & 0.0057 & 0.97 \\
\hline RMW-1 & 0.021 & - & 0.021 & - & 0.0033 & 0.90 \\
\hline RMW-2 & - & - & 0.094 & - & 0.0031 & 0.45 \\
\hline RMW-3 & - & - & 0.015 & - & - & 0.19 \\
\hline RMW-4 & - & - & 0.035 & - & - & 0.10 \\
\hline
\end{tabular}

a A hyphen (-) indicates the parameter was not detected. 
TABLE 5.8 Estimated Hazard Quotients for Nitroaromatic Compounds for a Hypothetical Future Resident ${ }^{\mathrm{a}}$

\begin{tabular}{|c|c|c|c|c|c|c|}
\hline \multirow[b]{2}{*}{ Well ID } & \multicolumn{6}{|c|}{ Estimated Hazard Quotient } \\
\hline & $1,3,5$-TNB & 1,3-DNB & 2,4,6-TNT & 2,4-DNT & 2,6-DNT & Total \\
\hline MW-1002 & 87 & 0.12 & 1.9 & 0.0018 & 0.33 & 89 \\
\hline MW-1004 & 0.61 & 0.17 & 0.54 & 0.0097 & 0.026 & 1.4 \\
\hline MW-1005 & $-{ }^{b}$ & - & - & - & - & - \\
\hline MW-1006 & 68 & 0.038 & 0.64 & 0.0062 & 0.064 & 69 \\
\hline MW-1007 & 0.15 & - & 0.0043 & - & 0.00065 & 0.15 \\
\hline MW-1008 & 0.063 & - & 0.011 & - & 0.0012 & 0.075 \\
\hline MW-1009 & - & - & - & - & - & - \\
\hline MW-1013 & - & - & - & 0.00051 & 0.00036 & 0.00087 \\
\hline MW-1014 & - & - & - & - & - & - \\
\hline MW-1015 & 4.1 & 0.043 & 0.16 & 0.0004 & 0.0058 & 4.3 \\
\hline MW-1016 & 0.27 & - & 0.017 & - & 0.0013 & 0.29 \\
\hline MW-1026 & - & - & - & - & - & - \\
\hline MW-1027 & 0.028 & - & 0.062 & 0.059 & 0.06 & 0.21 \\
\hline MW-1028 & - & - & - & - & - & - \\
\hline MW-1029 & - & - & - & - & 0.00031 & 0.00031 \\
\hline MW-1030 & - & - & 0.0012 & 0.00035 & 0.00087 & 0.0024 \\
\hline MW-1031 & - & - & - & - & - & - \\
\hline MW-1032 & 0.069 & - & 0.024 & 0.0037 & 0.0019 & 0.099 \\
\hline MW-1035 & - & - & - & - & - & - \\
\hline MW-1036 & - & - & - & - & - & - \\
\hline MW-1037 & - & - & - & 0.00024 & - & 0.00024 \\
\hline MW-1038 & - & - & - & - & - & - \\
\hline MW-1039 & - & - & - & - & - & - \\
\hline MW-1040 & - & - & - & - & - & - \\
\hline MW-1041 & - & - & - & - & - & - \\
\hline MW-1045 & - & - & - & - & - & - \\
\hline MW-1046 & - & - & - & - & - & - \\
\hline MW-1047 & - & - & - & - & - & - \\
\hline MW-1048 & - & - & - & - & - & - \\
\hline MW-1049 & - & - & - & - & - & - \\
\hline
\end{tabular}

a Nitroaromatic compounds were not detected in wells located south of the slough.

b A hyphen (-) indicates the parameter was not detected. 


\section{ECOLOGICAL RISK ASSESSMENT}

\subsection{SCOPE}

\subsubsection{Objectives}

The principal ecological resources associated with the QROU are the terrestrial biota and habitats at and south of the quarry proper and the aquatic biota and habitats at Femme Osage Slough and Little Femme Osage Creek. The ecological risk assessment for the QROU was designed to (1) determine whether current or future conditions in these habitats pose a potential adverse risk to terrestrial or aquatic biota and (2) determine if remediation (for protection of ecological resources) or further ecological investigation might be warranted. The results of this ecological risk assessment will assist DOE in the decision-making process for the QROU and, if remediation is warranted, will provide baseline ecological data to aid in the development of remedial action objectives and the screening and evaluation of remedial alternatives and technologies.

\subsubsection{Assessment Approach}

The QROU ecological risk assessment approach was based on the EPA Framework for Ecological Risk Assessment (EPA 1992b) and generally follows current EPA guidance for conducting ecological risk assessments (EPA 1989b). The approach consists of four phases: (1) problem formulation, (2) effects assessment, (3) exposure assessment, and (4) risk characterization. The results of the problem formulation phase for the QROU - which identified the rationale, approach, methods, and goals of the risk assessment - are presented in the work and sampling plans prepared for the QROU (DOE 1994a-b). The effects and exposure assessments were conducted with a combination of field investigations and uptake modeling, as well as evaluations of existing site and literature data. The field investigations conducted in support of this ecological risk assessment included surveys of terrestrial vegetation, small mammals, and threatened and endangered species; the methods used are described in the QROU sampling plan (DOE 1994b). The results of these surveys were used to evaluate population status and community structure of vegetation and wildlife that occur at or utilize the slough and quarry areas.

Although terrestrial biota might enter the quarry proper on occasion, the quarry provides little suitable habitat for vegetation or wildlife. During previous remedial activities, the quarry has been excavated to bedrock, and little or no soil remains to support vegetation. Exposure of vegetation or wildlife would be largely limited to contact with residual materials remaining deep within the cracks and crevices in the quarry walls and floor, and thus this material is not considered to represent a significant exposure route to ecological resources. Terrestrial wildlife might also utilize the quarry 
pond as a drinking source. However, the overall absence of suitable habitat within the quarry and the abundance of other drinking water sources in the area likely precludes more than very occasional use of the quarry pond by area wildlife. Furthermore, ponded water within the quarry is collected in the sump area and pumped to the quarry water treatment plant for treatment, thereby largely eliminating the potential for exposure of wildlife. Restoration of the quarry area, which is currently in the planning stages, will likely include engineering to prevent refilling of the quarry pond, as well as backfilling of some portions of the quarry with clean fill material, thus further reducing the potential for wildlife exposure. Therefore, the ecological risk assessment did not evaluate risks to ecological resources from potential exposure to surface water or soils within the quarry proper.

Existing data evaluated for this risk assessment included the results of tissue analyses of fish collected from Femme Osage Slough and of small mammals collected from the terrestrial habitats in the vicinity of the quarry proper. These data were used to quantify exposure to contaminants that might be present at the site. Exposure of wildlife species was also estimated by modeling contaminant uptake through aquatic pathways. Contaminant uptake was estimated in accordance with EPA guidance (EPA 1993). An applied daily dose (ADD) or a daily radiological dose to selected receptors was calculated for all appropriate exposure pathways from contaminated sediment and surface water. The equations and assumptions used to model uptake are discussed in detail in Section 3.4 .

\subsubsection{Risk Determination}

Two approaches were used to estimate risk to ecological resources: (1) ecological effects quotient (EEQ) and (2) weight-of-evidence. The weight-of-evidence approach (EPA 1992b) uses multiple lines of evidence to make a qualitative determination of whether a site poses a risk. For example, if the results of all field evaluations showed that adverse effects had occurred at the site, the weight-of-evidence determination would be that the site poses a risk to ecological receptors. Alternately, if no adverse effects were identified, the determination would be that the site poses no risk. Estimation of ecological risk by the EEQ method is analogous to using the quotient method to estimate noncarcinogenic human health risks (EPA 1989a). In the EEQ approach, the measured media concentration or predicted daily dose of a contaminant is compared with a benchmark media or daily dose concentration that represents a "safe" concentration. The ratio of the media/dose concentration to the benchmark value is the EEQ and provides the risk estimate; if the EEQ exceeds a value of 1.0, an adverse effect is possible and further ecological evaluations are warranted.

\subsection{ECOLOGICAL CHARACTERIZATION}

The following discussion presents a brief overview of the ecological setting of the QROU and the ecological resources known or expected to occur at or utilize habitats in the vicinity of the 
QROU. Detailed information on the ecological resources of the area is provided in the QROU RI report (MK-Ferguson Company and Jacobs Engineering Group 1997).

The QROU is in the Ozark Border Physiographic Province (Johnson 1987), which includes a narrow band along the lower Missouri River and the eastern edge of the state along the Mississippi River. This province has rugged hills and bluffs with deep, rich soils; deciduous forests; wide river valleys; and steep-sided sandstone canyons. Much of the land surrounding the quarry is part of the Busch Conservation Complex. Vegetation at the QROU is dominated by second-growth forest upland oak-hickory forest immediately around the quarry proper and cottonwood-sycamore bottomland forest south of the quarry proper. The St. Charles County well field land, located south of the quarry proper and between the Missouri River and Femme Osage Slough, consists primarily of agricultural land.

The principal aquatic habitats potentially affected by site-related contaminants are Little Femme Osage Creek and Femme Osage Slough; wetland habitats occur along each of these surface waters. Femme Osage Slough represents the most significant aquatic habitat associated with the QROU. This slough is a man-made oxbow lake that was formed when Femme Osage Creek was rerouted to flow south and east around the southern end of the well field, rather than along its historic east-northeast path to the Missouri River.

The Busch Conservation Complex contains a variety of habitats and supports a diversity of wildlife species. As part of the RI characterization of the QROU, surveys were conducted of reptiles and amphibians (herpetofauna), birds, and vegetation to identify biota that actually occur at or utilize the operable unit. In addition, fish and small mammal populations have been investigated in the past in support of the environmental monitoring program for the Weldon Spring site and as part of the Missouri Department of Conservation management activities at the Busch Conservation Complex. These data are presented in the RI report for the QROU (MK-Ferguson Company and Jacobs Engineering Group 1997). The biotic surveys at the QROU and vicinity have identified a diverse flora and fauna, comprising species typical of similar habitats in the region.

The U.S. Fish and Wildlife Service (Frazer 1995) has identified the potential for five federal-listed threatened or endangered species to occur in the vicinity of the QROU: three birds (bald eagle, peregrine falcon, interior least tern), one fish (pallid sturgeon), and one plant (decurrent false aster). The Fish and Wildlife Service has also identified several candidate species as possibly occurring in the area. The Missouri Department of Conservation has identified 13 state endangered and 19 state rare species for St. Charles County (Gaines 1988; Dickneite 1988; Figg 1991). However, many of these species are not expected to occur at the QROU area. Some of these species only' pass through the area during migration. For other species, suitable habitat is absent from the quarry. To date, only the bald eagle has been observed in the vicinity of the QROU (MK-Ferguson Company and Jacobs Engineering Group 1997), and all of the eagles were sighted near the Missouri River and away from the quarry proper. 


\subsection{CONTAMINANTS AND RESOURCES OF ECOLOGICAL CONCERN}

\subsubsection{Media and Habitats of Concern}

The media and areas of focus in the ecological risk assessment are surface water and sediment in Femme Osage Slough and Little Femme Osage Creek. No contaminated terrestrial habitats occur in this area. Characterization data for these media are summarized in Section 2.1.

\subsubsection{Ecological Receptors and Exposure Pathways}

The ecological receptors considered for this risk assessment were those species that inhabit or directly use Femme Osage Slough or Little Femme Osage Creek. Exposure of biota at these habitats to contaminants might occur by dermal uptake, ingestion of contaminated media, and food chain uptake. Fish and aquatic invertebrates would be the most likely biota to be exposed to, and adversely affected by, the contaminants in the slough and creek, and the principal exposure pathway would be dermal contact. Ingestion of contaminated sediments represents an additional exposure route for bottom-dwelling fish species that forage on or in sediments.

Dermal absorption also represents the principal exposure pathway for amphibian species that inhabit the slough or creek or use these habitats for reproduction. Among the reptile species observed or expected to occur at the QROU, only semiaquatic species such as the northern water snake and turtles would likely be exposed to contaminants at the slough or creek. For these species, food uptake, dermal uptake, and incidental ingestion of surface water and sediment represent the principal exposure routes. Birds that rest or forage at the slough and that might be exposed to contaminants include waterfowl, shorebirds, and wading birds. Possible mammalian receptors include terrestrial species, such as the white-tailed deer, that might come to the slough or creek to drink water. Among the threatened or endangered species, the bald eagle might forage at the slough on fish or waterfowl, and the principal exposure pathway for this species would be ingestion of contaminated food.

\subsection{EFFECTS AND EXPOSURE ASSESSMENTS}

The estimation of ecological risks included assessment of both effects and exposure. The purpose of the effects assessment was to document whether adverse impacts have occurred or are currently occurring at the site. The effects assessment in this ecological risk assessment was based primarily on qualitative and quantitative surveys of vegetation, fish, and wildlife that have been conducted in the past and specifically in support of the RI/FS process for the QROU. Exposure was evaluated on the basis of measured tissue concentrations of contaminants in fish and small mammals 
collected from the QROU, as well as modeled uptake and predicted daily doses to selected ecological receptors. Details regarding the surveys and tissue analyses are presented in the QROU sampling plan (DOE 1994b) and the RI report (MK-Ferguson Company and Jacobs Engineering Group 1997). The results of effects assessments and exposure assessments are discussed in Sections 6.4.1 and 6.4 .2 , respectively.

\subsubsection{Effects Assessments}

The evaluation of actual adverse effects to ecological resources at the QROU was based primarily on the results of the biotic surveys that have been conducted at the site (MK-Ferguson Company and Jacobs Engineering Group 1997). The results of the aquatic invertebrate, fish, herpetofauna, and bird surveys indicate the presence of relatively diverse communities consisting of species that would be expected to occur in the area. There were no obvious signs that these populations have been adversely affected by contamination associated with the QROU. In addition, no specimens collected or observed exhibited external signs of abnormal conditions, such as tumors, skin lesions, or physical deformities.

No adverse effects to the small mammal populations at the QROU are evident. The small mammal community at the site comprises species that are common to the area. No significant differences have been detected in the density of the most abundant species (deer mouse, the only species so evaluated) among the QROU and reference sites (Bethel et al. 1993), and no specimens have been reported to exhibit external abnormalities.

\subsubsection{Exposure Assessments}

Potential exposures of terrestrial biota were evaluated on the basis of tissue analyses and uptake modeling. Exposures of aquatic biota were considered to result from direct contact with contaminated media and were also evaluated on the basis of tissue analyses. Results of the tissue analyses of small mammals collected from the QROU area and of fish collected from Femme Osage Slough are summarized in Sections 6.4.2.1 and 6.4.2.2, respectively. The results of the uptake modeling for estimating daily contaminant doses to selected terrestrial biota are summarized in Section 6.4.2.3.

\subsubsection{Small Mammal Tissue Concentrations}

Small mammals from several taxa were collected from the QROU area and analyzed for whole-body radionuclide concentrations (Bethel et al. 1993). Reported tissue concentrations are 
listed in Table 6.1. ${ }^{4}$ Tissue concentrations of radionuclides in all samples collected from the QROU locations were lower than the corresponding soil concentrations, and a weak negative relationship between tissue and soil radionuclide concentration was indicated. In contrast, the reported tissue concentration of radium-228 (5.9 pCi/g) exceed the soil concentration of this radionuclide (3.1 pCi/g) at the reference site located on Femme Osage Creek upstream of its confluence with Little Femme Osage Creek. Specimens collected for tissue analysis were also dissected and examined for gross abnormalities; none were reported.

\subsubsection{Fish Tissue Concentrations}

Tissues from fish collected in the Weldon Spring area have been analyzed in a number of investigations associated with monitoring of the Weldon Spring site; the results of those studies are documented in other reports (MK-Ferguson Company and Jacobs Engineering Group 1995, 1997). More than 190 fish were collected and analyzed from 1987 to 1993 from a number of habitats, including Femme Osage Slough. Fish were also collected and analyzed from Lakes 33 and 37 in the Busch Conservation Area to provide background reference data.

Fish collected from Femme Osage Slough for tissue analysis included the bigmouth buffalo, yellow bullhead, white and black crappie, common carp, largemouth bass, and sunfish; tissues were analyzed for total uranium, lead, arsenic, and mercury. Fish collected from the reference lakes included the common carp, largemouth bass, sunfish, crappie, and channel catfish. Carp, buffalo, and bullhead are bottom-dwelling species that forage directly in and on the sediment, whereas the largemouth bass is a top predator. Details regarding the species sampled, the sampling and analysis methods, and results are presented in the RI report (MK-Ferguson Company and Jacobs Engineering Group 1997).

With a few exceptions, total uranium concentrations in fish samples from Femme Osage Creek were similar to the concentrations reported for fish from the background lakes. Bass and carp fillets and whole catfish and sunfish from the creek exhibited total uranium tissue concentrations greater than those reported from the reference lakes. Concentrations of arsenic and lead were also elevated in some creek-derived samples, especially lead in whole sunfish. The total uranium tissue concentrations reported for fish from Femme Osage Slough were within the range of tissue concentrations reported in the literature for fish collected from contaminated and background locations with which no adverse effects were associated (see DOE 1992, Appendix D).

4 All tables in this chapter have been placed at the end of the text (after Section 6.5.2). 


\subsubsection{Modeled Contaminant Intake}

Dose modeling was used to estimate exposure of selected receptor species for which no tissue analysis data were available. The modeling was performed to estimate contaminant uptake from ingestion of surface water, incidental ingestion of sediments, and ingestion of food. Although dermal exposure might represent an exposure route for some ecological receptors at the site, values for many of the parameters required to evaluate dermal absorption by wildlife have not been estimated (EPA 1993). Thus, doses from dermal exposure were not estimated for this risk assessment. For Femme Osage Slough, dose modeling for uptake of chemical contaminants was performed for the mallard, great blue heron, bald eagle, and white-tailed deer. For Little Femme Osage Creek, chemical contaminant dose modeling was performed for the white-tailed deer. The methods used to model contaminant uptake are summarized in Section 3.4, and detailed information is given in EPA (1993). For radiological intake, dose modeling was performed for all receptors to estimate radiological doses from the ingestion of food, surface water, and sediments.

\subsection{ECOLOGICAL RISK CHARACTERIZATION}

\subsubsection{Risks to Ecological Resources}

\subsubsection{Ecological Effects Quotient}

Following estimation of a dose to a terrestrial receptor, the potential for adverse ecological effects to the receptor species was estimated by examining the ratio between the predicted dose and a contaminant-specific benchmark value that represents a safe dose. For aquatic biota, risks were estimated by examining the ratio of surface water or sediment contaminant concentrations to contaminant- and media-specific benchmark values. This ratio is called the ecological effects quotient, or EEQ. Values of the EEQ may vary from zero to infinity, with values greater than 1.0 considered as demonstrating a potential risk to the receptor from the predicted dose.

Estimation of the EEQ requires the use of benchmark values that represent contaminant concentrations considered to be acceptable ("safe") for biota. Benchmark values are contaminantand species-specific, typically represent NOAEL concentrations, and may include media concentrations, food concentrations, tissue concentrations, or dose estimates. Benchmark values used for estimating the EEQ included EPA (1996) surface water and sediment ecotox threshold values and 
literature-derived values from a variety of sources (such as Sample et al. 1996; Suter and Tsao 1996; Jones et al. 1996; Talmadge and Opresko 1996).

The EEQ is calculated with the following equation:

$\mathrm{EEQ}=$ Estimated Dose $\div$ Benchmark Dose or

Measured $\mathrm{MC} \div$ Benchmark MC

where:

$$
\begin{aligned}
\text { EEQ }= & \text { ecological effects quotient; } \\
\text { Estimated Dose = } & \text { estimated ADD or radiological daily dose; } \\
\text { Benchmark Dose = } & \text { ADD or radiological daily dose reported to produce no } \\
& \text { adverse effect in the receptor species; } \\
\text { Measured MC = } & \text { reported contaminant concentration in media of concern; and } \\
\text { Benchmark MC = } & \text { media concentration reported to produce no adverse effects } \\
& \text { in, or be protective of, receptor species. }
\end{aligned}
$$

Suitable benchmark values were not available for some of the contaminants of ecological concern at the QROU, and estimation of an EEQ value for those contaminants was not possible. Benchmark values used for this risk assessment are presented in Table 6.2. The estimates of EEQ values and risk to fish and aquatic invertebrates for surface water and sediment are presented in Table 6.3.

At Femme Osage Slough and Little Femme Osage Creek, a number of the COECs for which aquatic benchmark values were available are present in the surface water and sediments at concentrations that potentially pose a risk to aquatic biota (Table 6.3). Higher EEQ values indicated potential risk for uranium, aluminum, and barium in surface water. No risk is indicated for ingestion of uranium in sediment. For the highest level of uranium in slough sediment, a fish would have to consume 50-500\% (depending on an exposure time of 1 to 10 years) of its body weight in contaminated sediment daily to approach the $1 \mathrm{rad} / \mathrm{d}$ dose limit. This level of sediment ingestion is not considered likely.

Although some of the surface water and sediment EEQ values indicate a potential for adverse effects to aquatic biota, results of fish surveys do not indicate any obvious adverse ecological impacts to be occurring at the slough or the creek. 
The risk levels identified for aluminum, antimony, barium, manganese, and uranium. were estimated by comparing maximum reported site concentrations to benchmark concentrations considered protective of biota. If a potential for adverse risk is indicated, then further evaluation is warranted to determine if actual impacts are occurring. This approach may greatly overestimate actual exposures and risks to aquatic biota by limiting exposures to discrete hot spots and not the entire site. For example, the maximum uranium concentration reported since $1987(6,000 \mu \mathrm{g} / \mathrm{L}$ ) was used to calculate an EEQ risk value of 2,300. In contrast, the maximum reported uranium concentration reported since 1995 following bulk waste removal from the quarry is $78 \mu \mathrm{g} / \mathrm{L}$. Use of this value (as was done for the human health risk assessment) gives an EEQ risk estimate of 30.

The calculated risk estimate, regardless of its value, does not indicate that adverse effects or impacts are occurring, or have occurred in the past, at the site. The risk estimates employ no sitespecific biological or ecological data and are based only on a literature-derived benchmark value and the maximum reported site concentration. In contrast to the EEQ-based risks estimated for the slough and creek, site-specific field evaluations of the aquatic invertebrate and fish communities did not identify any adverse impacts to aquatic biota at the slough or creek.

For terrestrial biota, EEQ values were calculated on the basis of the predicted daily dose estimates (see Section 3.4.3) and available benchmark values, such as the wildlife benchmark values developed by Sample et al. (1996) and Talmadge and Opresko (1996). The estimated EEQ values and risks to terrestrial wildlife using Femme Osage Slough are presented in Tables 6.4 through 6.6; values for white-tailed deer using the slough and Little Femme Osage Creek are presented in Table 6.7. No risks were identified for any of the modeled ecological receptors. For most pathways and contaminants, the estimated EEQ risk values were well below 0.01, and EEQ risk estimates summed across all pathways were typically less than 0.1 for all contaminants for which benchmark values were available.

\subsubsection{Weight of Evidence}

A number of field investigations were conducted to gather evidence demonstrating the presence or absence of adverse impacts to ecological resources at the OU. These investigations included biotic surveys of aquatic invertebrates, fish, vegetation, herpetofauna, birds, and small mammals (MK-Ferguson Company and Jacobs Engineering Group 1997); tissue analyses; and small mammal necropsies. On the basis of these site-specific investigations, there is no evidence of past or current adverse impacts to site biota. Thus, these lines of evidence suggest that the current conditions at the OU pose little or no risk to ecological resources at the QROU. 


\subsubsection{Uncertainty}

Several uncertainties could affect the estimated ADD and EEQ values and the final interpretation and incorporation of those values into the ecological risk assessment and remedial decisions for the QROU. These uncertainties are associated with (1) the model assumption that complete transfer and assimilation of contaminants occurs between trophic levels, (2) use of physiological and ecological data from different populations or taxa, (3) derivation of benchmark values, and (4) use of the EEQ to estimate risk.

The transfer and assimilation of contaminants between and within trophic levels is affected by a variety of factors not considered in the uptake models. These factors include, but are not limited to, (1) contaminant solubility in biological fluids, (2) location of the contaminant within food items relative to the portion of the food item eaten, (3) species metabolism, (4) contaminant biotransformation, and (5) depuration (natural elimination of the contaminant from the body). It is unlikely that the transfer or assimilation of a contaminant is $100 \%$ efficient, although for some biota, efficiency may approach $100 \%$. Thus, the assumption of $100 \%$ transfer and assimilation overestimates contaminant movement and assimilation within food chains and results in conservative estimates of risk.

In the absence of species-specific data, the uptake models use exposure factors (such as ingestion rate) that were estimated with allometric equations developed from data for other taxa. Because of unique biological differences among taxa, this approach may overestimate or underestimate the values of some exposure factors and, thus, the corresponding ADD and EEQ values. Interspecific data extrapolations are typically done for human health risk assessments and employ uncertainty multipliers to increase the conservative nature of the assessment. Similarly, benchmark values were not available for some of the species and contaminants of concern, and many of the benchmark values used to estimate EEQ values were derived for taxa other than those present at the QROU. Thus, the uncertainty associated with the derivation of benchmark values is similar to that identified for the use of allometrically derived exposure factors in the uptake models.

Finally, a number of uncertainties are inherent in the use of the EEQ for estimating risks to ecological receptors. Use of the EEQ does not differentiate between long-term and short-term impacts to biota, does not consider synergistic or antagonistic interactions among contaminants, and is only as good as the estimates of ADD and benchmark values and their associated levels of uncertainties. However, estimation of the $\mathrm{ADD}$ and $\mathrm{EEQ}$ values involved the use of very conservative assumptions regarding contaminant uptake (e.g., 100\% contaminant assimilation, no contaminant excretion, and contaminant concentration in food being equal to the concentration in sediment). Thus, even with the uncertainties associated with the ADD and EEQ values, the conservative bias of the risk estimation makes it unlikely that the actual doses experienced by wildlife in the area would result in EEQ values suggesting unacceptable risks. 


\subsubsection{Ecological Significance}

Although the EEQ risk estimates identify a potential for adverse effects to aquatic biota for Femme Osage Slough and Little Femme Osage Creek, site-specific field investigations (biotic surveys and tissue analyses) found no evidence to indicate that the aquatic communities in the slough and creek have been or are currently being affected by the contaminant levels in the surface water or sediment. However, if impacts were incurred, they would be limited to the biota inhabiting the slough and the lower reaches of Little Femme Osage Creek and would not be expected to adversely affect the overall condition of ecological resources in the area. The fish species inhabiting the slough and creek are all common species that are widespread throughout the Midwest and are generally abundant in suitable habitats. 
TABLE 6.1 Whole-Body Radionuclide Concentrations in Tissue of Small Mammals Collected from the QROU and Reference Locations

\begin{tabular}{|c|c|c|c|c|c|c|c|}
\hline \multirow[b]{2}{*}{ Site } & \multirow[b]{2}{*}{ Species $^{\mathrm{a}}$} & \multicolumn{6}{|c|}{ Concentration $(\mathrm{pCi} / \mathrm{g})$} \\
\hline & & Uranium, Total & Radium-226 & Radium-228 & Thorium-228 & Thorium-230 & Thorium-232 \\
\hline Quarry perimeter & Deer mouse & $\begin{array}{c}0.03 \\
(2.05)^{b}\end{array}$ & $\begin{array}{c}0.25 \\
(3.40)\end{array}$ & $\begin{array}{c}1.11 \\
(6.40)\end{array}$ & $\begin{array}{c}0.15 \\
(1.40)\end{array}$ & $\begin{array}{r}<0.01 \\
(1.30)\end{array}$ & $\begin{array}{c}0.01 \\
(1.10)\end{array}$ \\
\hline Slough, VP9 & Deer mouse & $\begin{array}{c}<0.01-0.03 \\
\quad(5.28)\end{array}$ & $\begin{array}{c}0.28-0.4 \\
(3.10)\end{array}$ & $\begin{array}{c}0.79-0.90 \\
(2.43)\end{array}$ & $\begin{array}{c}0.02-0.04 \\
(0.76)\end{array}$ & $\begin{array}{c}<0.01-0.01 \\
(0.84)\end{array}$ & $\begin{array}{c}0.01 \\
(0.81)\end{array}$ \\
\hline Slough & Deer mouse & $\begin{array}{c}0.03 \\
(2.04)\end{array}$ & $\begin{array}{c}1.14 \\
(3.50)\end{array}$ & $\begin{array}{c}1.12 \\
(2.42)\end{array}$ & $\begin{array}{c}0.02 \\
(0.69)\end{array}$ & $\begin{array}{c}0.02 \\
(0.84)\end{array}$ & $\begin{array}{c}0.02 \\
(0.70)\end{array}$ \\
\hline \multirow[t]{2}{*}{ Well field } & Deer mouse & $\begin{array}{c}0.38 \\
(2.05)\end{array}$ & $\begin{array}{c}1.13 \\
(3.50)\end{array}$ & $\begin{array}{c}1.40 \\
(3.42)\end{array}$ & $\begin{array}{c}0.01 \\
(0.79)\end{array}$ & $\begin{array}{c}0.02 \\
(0.88)\end{array}$ & $\begin{array}{r}<0.01 \\
(0.80)\end{array}$ \\
\hline & Composite $^{c}$ & 0.07 & 0.36 & 0.92 & 0.02 & $<0.01$ & $<0.01$ \\
\hline Little Femme Osage Creek & Deer mouse & $\begin{array}{c}0.35 \\
(1.91)\end{array}$ & $\begin{array}{c}0.25 \\
(2.60)\end{array}$ & $\begin{array}{c}1.75 \\
(3.03)\end{array}$ & $\begin{array}{c}0.01 \\
(0.82)\end{array}$ & $\begin{array}{c}0.01 \\
(0.86)\end{array}$ & $\begin{array}{c}0.01 \\
(0.76)\end{array}$ \\
\hline Upper Little Femme Osage Creek ${ }^{d}$ & Composite & $\begin{array}{c}0.07 \\
(1.23)\end{array}$ & $\begin{array}{c}0.31 \\
(2.20)\end{array}$ & $\begin{array}{c}0.68 \\
(4.40)\end{array}$ & $\begin{array}{c}0.03 \\
(0.80)\end{array}$ & $\begin{array}{c}0.01 \\
(0.80)\end{array}$ & $\begin{array}{c}0.01 \\
(0.70)\end{array}$ \\
\hline Femme Osage Creek ${ }^{\mathrm{e}}$ & Deer mouse & $\begin{array}{c}0.34 \\
(1.87)\end{array}$ & $\begin{array}{c}0.34 \\
(3.00)\end{array}$ & $\begin{array}{c}5.90 \\
(3.10)\end{array}$ & $\begin{array}{c}0.20 \\
(0.94)\end{array}$ & $\begin{array}{c}<0.01 \\
(0.96)\end{array}$ & $\begin{array}{c}<0.01 \\
(0.93)\end{array}$ \\
\hline
\end{tabular}

a Concentrations reported for composite sample of two individuals of the indicated species unless otherwise noted.

b Value in parentheses is the reported soil concentration of the radionuclide at the site.

c Composite samples comprised one deer mouse and one western harvest mouse.

d Reference site in bottomland forest along Little Femme Osage Creek north of State Route 94.

e Reference site in bottomland forest along Femme Osage Creek upstream of its confluence with Little Femme Osage Creek.

Source: Bethel et al. (1993). 
TABLE 6.2 Benchmark Values Used for Estimating EEQs for Aquatic and Terrestrial Biota Utilizing Femme Osage Slough and Little Femme Osage Creek ${ }^{\text {a }}$

\begin{tabular}{|c|c|c|c|c|c|c|}
\hline \multirow[b]{2}{*}{ Contaminant } & \multicolumn{2}{|c|}{ Aquatic Biota } & \multirow[b]{2}{*}{$\begin{array}{c}\text { Mallard }^{c} \\
(\mathrm{mg} / \mathrm{kg}-\mathrm{d})\end{array}$} & \multirow[b]{2}{*}{$\begin{array}{c}\text { Great Blue } \\
\text { Heron }^{\mathrm{c}} \\
(\mathrm{mg} / \mathrm{kg}-\mathrm{d})\end{array}$} & \multirow[b]{2}{*}{$\begin{array}{c}\text { Bald Eagle }^{c} \\
\text { (mg/kg-d) }\end{array}$} & \multirow[b]{2}{*}{$\begin{array}{l}\text { White-Tailed } \\
\text { Deerc } \\
\text { (mg/kg-d) }\end{array}$} \\
\hline & $\begin{array}{l}\text { Surface } \\
\text { Water } \\
(\mu \mathrm{g} / \mathrm{L})\end{array}$ & $\begin{array}{l}\text { Sediment } \\
(\mathrm{mg} / \mathrm{kg})\end{array}$ & & & & \\
\hline \multicolumn{7}{|l|}{ Metals } \\
\hline Aluminum & $87^{d}$ & NBA & 109.7 & 109.7 & 109.7 & 0.29 \\
\hline Antimony & $30^{\mathrm{e}}$ & $2^{f}$ & NBA & NBA & NBA & $\mathrm{NC}$ \\
\hline Arsenic & 190 & $8.2^{\mathrm{f}}$ & 5.14 & 5.14 & 5.14 & 0.02 \\
\hline Barium & $4.0^{\mathrm{e}}$ & NBA & 20.8 & 20.8 & 20.8 & 1.50 \\
\hline Beryllium & $0.66^{\mathrm{e}}$ & NBA & NBA & NBA & NBA & $\mathrm{NC}$ \\
\hline Cadmium & $2.39^{\mathrm{g}}$ & $1.2^{\mathrm{f}}$ & 1.45 & 1.45 & 1.45 & 0.27 \\
\hline Calcium & $116 \mathrm{mg} / \mathrm{L}^{\mathrm{h}}$ & NBA & NBA & NBA & NBA & NBA \\
\hline Chromium & $11^{\mathrm{g}}$ & $81.0^{\mathrm{f}}$ & 1.00 & 1.00 & 1.00 & 0.92 \\
\hline Copper & $26.6^{\mathrm{g}}$ & $34.0^{\mathrm{f}}$ & 47.0 & 47.0 & 47.0 & 4.30 \\
\hline Iron & $1.0 \mathrm{mg} / \mathrm{L}$ & NBA & NBA & NBA & NBA & NBA \\
\hline Lead & $10.7^{\mathrm{g}}$ & $47^{\mathrm{f}}$ & 1.13 & 1.13 & 1.13 & 2.24 \\
\hline Lithium & $14^{e}$ & NBA & NBA & NBA & NBA & $\mathrm{NC}$ \\
\hline Magnesium & $82 \mathrm{mg} / \mathrm{L}^{\mathrm{h}}$ & NBA & NBA & NBA & NBA & NBA \\
\hline Manganese & $120^{\mathrm{e}}$ & $460^{f}$ & 997 & 997 & 997 & 25.0 \\
\hline Mercury & $1.3^{\mathrm{i}}$ & $0.15^{\mathrm{f}}$ & 0.0064 & 0.0064 & 0.0064 & 0.36 \\
\hline Molybdenum & $370^{\mathrm{e}}$ & NBA & NBA & NBA & NBA & $\mathrm{NC}$ \\
\hline Nickel & $351^{g}$ & $20.9^{f}$ & 77.4 & 77.4 & 77.4 & 11.2 \\
\hline Potassium & $53 \mathrm{mg} / \mathrm{L}^{\mathrm{h}}$ & NBA & NBA & NBA & NBA & NBA \\
\hline Selenium & 5 & NBA & 0.5 & 0.5 & 0.5 & 0.06 \\
\hline Silver & $20.8^{j}$ & $1.0^{\mathrm{f}}$ & NBA & NBA & NBA & $\mathrm{NC}$ \\
\hline Sodium & $680 \mathrm{mg} / \mathrm{L}^{\mathrm{h}}$ & NBA & NBA & NBA & NBA & NBA \\
\hline Strontium & $1,500^{e}$ & NBA & NBA & NBA & NBA & $\mathrm{NC}$ \\
\hline Thallium & $12^{\mathrm{e}}$ & NBA & 0.00007 & 0.00007 & 0.00001 & 0.002 \\
\hline Uranium (chemical), total & $2.6^{\mathrm{e}}$ & NBA & 16.0 & 16.0 & 1.60 & 0.46 \\
\hline Uranium (radiological) $^{\mathrm{k}}$ & $1.0 \mathrm{rad} / \mathrm{d}$ & $1.0 \mathrm{rad} / \mathrm{d}$ & $0.10 \mathrm{rad} / \mathrm{d}$ & $0.10 \mathrm{rad} / \mathrm{d}$ & $0.10 \mathrm{rad} / \mathrm{d}$ & $0.10 \mathrm{rad} / \mathrm{d}$ \\
\hline Vanadium & $20^{\mathrm{e}}$ & NBA & 11.4 & 11.4 & 1.14 & 0.05 \\
\hline Zinc & $233.9^{\mathrm{g}}$ & $150^{\mathrm{f}}$ & 14.5 & 14.5 & 1.45 & 44.9 \\
\hline \multicolumn{7}{|l|}{ Inorganic anions } \\
\hline Fluoride & $15 \mathrm{mg} / \mathrm{L}$ & NBA & 7.8 & 7.8 & 7.8 & 11.4 \\
\hline Nitrate & $90 \mathrm{mg} / \mathrm{L}^{l}$ & NBA & 5.07 & 5.07 & 0.51 & 178.0 \\
\hline Sulfate & NBA & NBA & NBA & NBA & NBA & NBA \\
\hline
\end{tabular}


Aquatic Biota

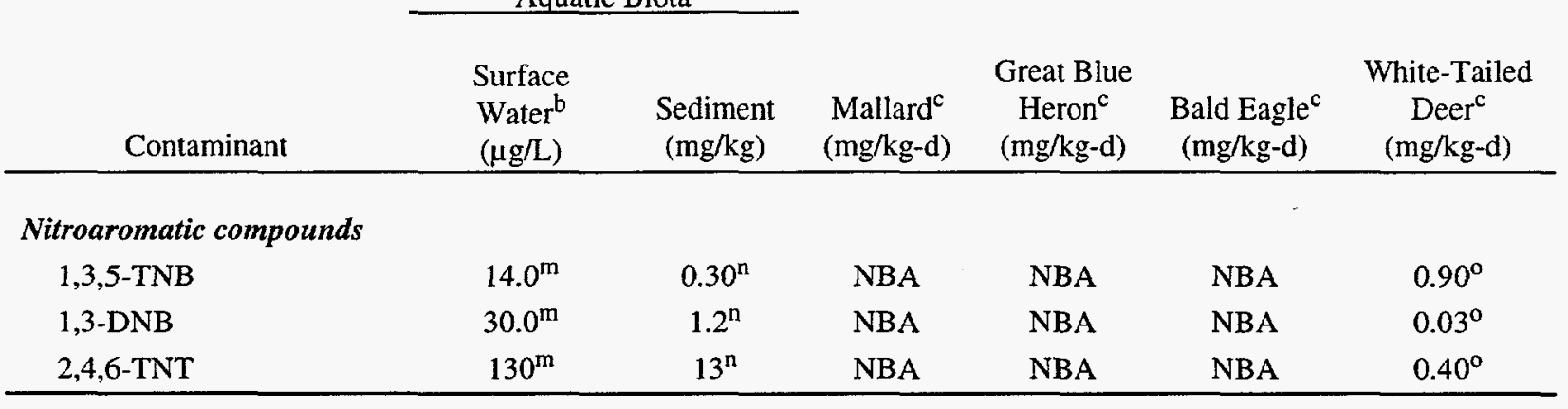

a $\mathrm{NBA}=$ no benchmark (value) available; $\mathrm{NC}=$ no concern (not a contaminant of concern for the indicated medium).

b Benchmark values are EPA chronic value water quality standards (1994) for the protection of freshwater biota unless otherwise noted.

c Benchmark values are NOAEL toxicological benchmarks developed by Sample et al. (1996) unless otherwise noted.

d National ambient water quality chronic value presented in Suter and Tsao (1996).

e Tier II secondary chronic value developed by Suter and Tsao (1996).

$f$ Based on ER-L value reported in Jones et al. (1996).

g National ambient water quality hardness-dependent value calculated using hardness $=258.9$ mg equivalent calcium carbonate $\left(\mathrm{CaCO}_{3}\right)$ per liter. See EPA (1994) or EPA (1996) for appropriate formula.

h Lowest chronic value reported by Suter and Tsao (1996).

i EPA (1996) ecotox threshold chronic value.

j National ambient water quality criterion as reported in Suter and Tsao (1996); hardness-dependent value calculated using hardness value of $258.9 \mathrm{mg}$ equivalent $\mathrm{CaCO}_{3}$ per liter.

k Dose limits specified in 10 CFR Part 834 ("Radiation Protection of the Public and the Environment"). Radiological values are $\mathrm{rad} / \mathrm{d}$.

$l$ No water quality criterion available; EPA (1986) identifies the concentration as a potentially safe maximum concentration.

$\mathrm{m}$ Based on chronic value developed by Talmadge and Opresko (1996).

n Sediment quality criterion developed by Talmadge and Opresko (1996).

- Based on NOAEL value developed by Talmadge and Opresko (1996). 
TABLE 6.3 Estimated EEQs for Exposure of Fish and Aquatic Invertebrates to Surface Water and Sediments in the Femme Osage Slough and Little Femme Osage Creek ${ }^{\mathrm{a}}$

\begin{tabular}{lcc}
\hline \multicolumn{1}{c}{ Contaminant ${ }^{\mathrm{b}}$} & $\begin{array}{c}\text { Femme } \\
\text { Osage Slough }\end{array}$ & $\begin{array}{c}\text { Little Femme } \\
\text { Osage Creek }\end{array}$ \\
\hline $\begin{array}{l}\text { Surface Water } \\
\text { Aluminum }\end{array}$ & & \\
Barium & 80.5 & 2.7 \\
Calcium & 84.2 & 67.5 \\
Chromium & $\mathrm{NC}$ & 1.53 \\
Iron & 2.82 & 5.18 \\
Lead & 7.82 & 3.10 \\
Manganese & 1.12 & 1.12 \\
Uranium (chemical), total & 10.6 & 3.80 \\
Uranium (radiological) & 2,300 & $\mathrm{NC}$ \\
Vanadium & 0.02 & $\mathrm{NC}$ \\
& 0.89 & 1.12 \\
Sediment & & \\
Antimony & & \\
Arsenic & $\mathrm{NC}$ & 17.8 \\
Cadmium & 2.65 & 1.08 \\
Lead & 3.50 & 1.08 \\
Manganese & 1.03 & 0.33 \\
Mercury & 2.35 & 1.67 \\
Nickel & 6.60 & 0.53 \\
Zinc & 1.32 & 0.95 \\
\hline
\end{tabular}

a EEQ values exceeding 1.0 are indicative of potential risk to ecological resources.

b Included are only those contaminants for which benchmark values were available (see Table 6.2).

c $\mathrm{NC}=$ contaminant eliminated during screening process and not considered a COEC for the media and location. 
TABLE 6.4 Estimated EEQs for the Mallard ${ }^{\mathrm{a}}$

\begin{tabular}{lrrrr}
\hline \multicolumn{1}{c}{ Contaminant } & $\begin{array}{c}\text { Water } \\
\text { Ingestion }\end{array}$ & $\begin{array}{c}\text { Sediment } \\
\text { Ingestion }\end{array}$ & $\begin{array}{c}\text { Food } \\
\text { Ingestion }\end{array}$ & Total \\
\hline Metals & & & & \\
Aluminum & & & & \\
Arsenic & $<0.01$ & $<0.01$ & 0.03 & 0.03 \\
Barium & $<0.01$ & $<0.01$ & $<0.01$ & $<0.01$ \\
Cadmium & $<0.01$ & $<0.01$ & $<0.01$ & $<0.01$ \\
Chromium & $<0.01$ & $<0.01$ & $<0.01$ & $<0.01$ \\
Copper & $<0.01$ & $<0.01$ & 0.01 & 0.01 \\
Lead & $<0.01$ & $<0.01$ & $<0.01$ & $<0.01$ \\
Manganese & $<0.01$ & $<0.01$ & 0.01 & 0.01 \\
Mercury & $<0.01$ & $<0.01$ & $<0.01$ & $<0.01$ \\
Molybdenum & $<0.01$ & $<0.01$ & 0.02 & 0.02 \\
Nickel & $<0.01$ & $<0.01$ & 0.01 & 0.01 \\
Selenium & $<0.01$ & $<0.01$ & $<0.01$ & $<0.01$ \\
Uranium (chemical), total & $<0.01$ & $<0.01$ & $<0.01$ & $<0.01$ \\
Uranium (radiological) & $<0.01$ & $<0.01$ & $\mathrm{NC}$ & $<0.01$ \\
Vanadium & $<0.01$ & $<0.01$ & $<0.01$ & $<0.01$ \\
Zinc & $<0.01$ & $<0.01$ & 0.01 & 0.01 \\
& & & &
\end{tabular}

\section{Inorganic anion}

Nitrate

$<0.01$

$<0.01$

$<0.01$

$<0.01$

a EEQ values below 1.0 indicate no potential risk to ecological resources.

b $\mathrm{NC}=$ not considered; food ingestion was not considered a significant pathway and was not evaluated for radiological risks. 
TABLE 6.5 Estimated EEQs for the Great Blue Heron ${ }^{a}$

\begin{tabular}{lrrrr}
\hline \multicolumn{1}{c}{ Contaminant } & $\begin{array}{c}\text { Water } \\
\text { Ingestion }\end{array}$ & $\begin{array}{c}\text { Sediment } \\
\text { Ingestion }\end{array}$ & $\begin{array}{c}\text { Food } \\
\text { Ingestion }\end{array}$ & Total \\
\hline Metals & & & & \\
Aluminum & $<0.01$ & $<0.01$ & 0.03 & 0.03 \\
Arsenic & $<0.01$ & $<0.01$ & $<0.01$ & $<0.01$ \\
Barium & $<0.01$ & $<0.01$ & $<0.01$ & $<0.01$ \\
Cadmium & $<0.01$ & $<0.01$ & $<0.01$ & $<0.01$ \\
Chromium & $<0.01$ & $<0.01$ & $<0.01$ & $<0.01$ \\
Copper & $<0.01$ & $<0.01$ & $<0.01$ & $<0.01$ \\
Lead & $<0.01$ & $<0.01$ & 0.01 & 0.01 \\
Manganese & $<0.01$ & $<0.01$ & $<0.01$ & $<0.01$ \\
Mercury & $<0.01$ & $<0.01$ & 0.03 & 0.03 \\
Nickel & $<0.01$ & $<0.01$ & $<0.01$ & $<0.01$ \\
Selenium & $<0.01$ & $<0.01$ & 0.01 & 0.01 \\
Uranium (chemical), total & $<0.01$ & $<0.01$ & $<0.01$ & $<0.01$ \\
Uranium (radiological) & $<0.01$ & $<0.01$ & $\mathrm{NC}$ & $<0.01$ \\
Vanadium & $<0.01$ & $<0.01$ & $<0.01$ & 0.01 \\
Zinc & $<0.01$ & $<0.01$ & $<0.01$ & $<0.01$ \\
& & & & \\
Inorganic anions & $<0.01$ & $<0.01$ & $<0.01$ & $<0.01$ \\
Fluoride & $<0.01$ & $<0.01$ & $<0.01$ & $<0.01$ \\
Nitrate & & & &
\end{tabular}

a EEQ values below 1.0 indicate no potential risk to ecological resources.

b $\mathrm{NC}=$ not considered; food ingestion was not considered a significant pathway and was not evaluated for radiological risks. 
TABLE 6.6 Estimated EEQs for the Bald Eagle

\begin{tabular}{lcrr}
\hline \multicolumn{1}{c}{ Contaminant } & $\begin{array}{c}\text { Water } \\
\text { Ingestion }\end{array}$ & $\begin{array}{c}\text { Food } \\
\text { Ingestion }\end{array}$ & Total \\
\hline Metals & & & \\
Aluminum & & & \\
Arsenic & $<0.01$ & 0.02 & 0.02 \\
Barium & $<0.01$ & $<0.01$ & $<0.01$ \\
Cadmium & $<0.01$ & $<0.01$ & $<0.01$ \\
Chromium & $<0.01$ & $<0.01$ & $<0.01$ \\
Copper & $<0.01$ & $<0.01$ & $<0.01$ \\
Lead & $<0.01$ & $<0.01$ & $<0.01$ \\
Manganese & $<0.01$ & $<0.01$ & $<0.01$ \\
Mercury & $<0.01$ & $<0.01$ & $<0.01$ \\
Nickel & $<0.01$ & 0.02 & 0.02 \\
Selenium & $<0.01$ & $<0.01$ & $<0.01$ \\
Uranium (chemical), total & $<0.01$ & $<0.01$ & $<0.01$ \\
Uranium (radiological) & $<0.01$ & $<0.01$ & $<0.01$ \\
Vanadium & $<0.01$ & $\mathrm{NC}$ & $<0.01$ \\
Zinc & $<0.01$ & $<0.01$ & $<0.01$ \\
& $<0.01$ & $<0.01$ & $<0.01$ \\
Inorganic anions & & & \\
Fluoride & & $<0.01$ & $<0.01$ \\
Nitrate & $<0.01$ & $<0.01$ & $<0.01$ \\
\hline
\end{tabular}

a EEQ values below 1.0 indicate no potential risk to ecological resources.

b $\mathrm{NC}=$ not considered; food ingestion was not considered a significant pathway and was not evaluated for radiological risks. 
TABLE 6.7 Estimated EEQs for the White-Tailed Deer

\begin{tabular}{|c|c|c|c|}
\hline \multirow[b]{2}{*}{ Contaminant } & \multicolumn{2}{|c|}{ Water Ingestion } & \multirow[b]{2}{*}{ Total } \\
\hline & $\begin{array}{c}\text { Femme Osage } \\
\text { Slough }\end{array}$ & $\begin{array}{c}\text { Little Femme } \\
\text { Osage Creek }\end{array}$ & \\
\hline \multicolumn{4}{|l|}{ Metals } \\
\hline Aluminum & 0.07 & $<0.01$ & 0.07 \\
\hline Arsenic & $<0.01$ & $<0.01$ & $<0.01$ \\
\hline Barium & $<0.01$ & $<0.01$ & $<0.01$ \\
\hline Cadmium & $<0.01$ & $<0.01$ & $<0.01$ \\
\hline Chromium & $<0.01$ & $<0.01$ & $<0.01$ \\
\hline Copper & $<0.01$ & $\mathrm{ND}^{\mathrm{b}}$ & $<0.01$ \\
\hline Lead & $<0.01$ & $<0.01$ & $<0.01$ \\
\hline Manganese & $<0.01$ & $<0.01$ & $<0.01$ \\
\hline Mercury & $<0.01$ & $<0.01$ & $<0.01$ \\
\hline Nickel & $<0.01$ & $<0.01$ & $<0.01$ \\
\hline Selenium & $<0.01$ & $<0.01$ & $<0.01$ \\
\hline Uranium (chemical), total & 0.04 & $<0.01$ & 0.04 \\
\hline Uranium (radiological) & 0.04 & $\mathrm{NE}^{\mathrm{c}}$ & 0.04 \\
\hline Vanadium & $<0.01$ & $<0.01$ & $<0.01$ \\
\hline Zinc & $<0.01$ & $<0.01$ & $<0.01$ \\
\hline \multicolumn{4}{|l|}{ Inorganic anions } \\
\hline Fluoride & $<0.01$ & $<0.01$ & $<0.01$ \\
\hline Nitrate & $<0.01$ & $<0.01$ & $<0.01$ \\
\hline \multicolumn{4}{|l|}{ Nitroaromatic compounds } \\
\hline $1,3,5-\mathrm{TNB}$ & ND & $<0.01$ & $<0.01$ \\
\hline 2,4,6-TNT & ND & $<0.01$ & $<0.01$ \\
\hline
\end{tabular}

a EEQ values below 1.0 indicate no potential risk to ecological resources.

b $\mathrm{ND}=$ not detected in media of concern.

c $\mathrm{NE}=$ not evaluated - water ingestion from Little Femme Osage Creek was not considered a significant pathway for radiological risk and was not evaluated. 


\section{SUMMARY AND CONCLUSIONS}

A combined baseline risk assessment addressing human health and ecological impacts was performed to evaluate conditions at the QROU. The human health component of this BRA included an evaluation of the radiological and chemical risks from residual contamination at the quarry proper (after removal of ponded water and bulk waste) and at Femme Osage Slough. The ecological assessment focused on impacts to biota from surface water and sediment contamination at Femme Osage Slough and Little Femme Osage Creek.

\subsection{HUMAN HEALTH RISK ASSESSMENT}

Data were evaluated to identify site-related COPCs for the following media and areas included in the QROU: residual soils and fractures at the quarry proper; surface water and sediment from Femme Osage Slough, Little Femme Osage Creek, and Femme Osage Creek; and groundwater.

The radioactive COPCs include uranium, radium-226, radium-228, and thorium (primarily thorium-230). Chemical COPCs include metals and nitroaromatic compounds. PCBs were also detected in the quarry proper soils. The COPCs for the various areas are listed in Table 2.1.

Potential exposure was evaluated for a recreational visitor at the quarry proper. This approach is considered consistent with current and likely future land use at the quarry. A similar scenario was also evaluated to determine potential exposures to contaminants at Femme Osage Slough. The estimates for the slough should provide an upper bound for those for the creeks because contaminant concentrations reported for the creeks are generally lower than those reported for the slough. Although contact with groundwater by a current or future receptor is an incomplete pathway, bounding calculations were performed for a hypothetical resident. Standard EPA-recommended exposure parameters and verified toxicity RfDs and slope factors were used in the calculations presented in this risk assessment.

The results of the calculations for the quarry proper and Femme Osage Slough recreational visitor indicate that radiological and chemical risks are below to within the target risk range of $1 \times 10^{-6}$ to $1 \times 10^{-4}$. Hazard indices are also less than 1 , indicating that systemic toxicity is not a concern. The estimated radiological risk for the recreational visitor exposed to multiple locations and media via multiple pathways is $3 \times 10^{-5}$. The chemical carcinogenic risk and hazard index for this same receptor are estimated to be $4 \times 10^{-6}$ and 0.05 , respectively. These estimates are within EPA's acceptable limits. Table 7.1 summarizes human health risk estimates for the quarry area. 
For presentation purposes, carcinogenic health risks and hazard quotients were also estimated for a hypothetical resident for ingestion of and dermal contact with groundwater. Radiological risks ranged from $1 \times 10^{-7}$ to $4 \times 10^{-3}$. Chemical carcinogenic risks ranged from $1 \times 10^{-7}$ to $1 \times 10^{-4}$. Risks greater than $1 \times 10^{-4}$ were estimated for wells located south of the quarry and north of the slough. Hazard quotients greater than 1 were also estimated for a few wells located in this area.

\subsection{ECOLOGICAL RISK ASSESSMENT}

Femme Osage Slough and Little Femme Osage Creek are the principal habitats at the QROU where biota might be exposed to quarry-related contaminants. Evaluation of surface water and sediment characterization data for the slough and creek identified a number of metals present in these media as potential contaminants of ecological concern. Current levels of aluminum, barium, chromium, iron, manganese, and total uranium in the surface water and arsenic, cadmium, lead, manganese, mercury, nickel, and zinc in the sediment of both the slough and the creek have been identified as posing a potential risk to the aquatic biota that use these habitats. Levels of calcium, lead, and vanadium in surface water were also identified as posing a potential risk; however, the EEQ values were only slightly greater than 1.0. Similarly, sediment EEQ values only slightly exceeded 1.0 for lead, nickel, and zinc. No risks were indicated from nitroaromatic compounds in either medium. Modeling results indicated no risks to terrestrial wildlife receptors foraging in Femme Osage Slough or drinking from Little Femme Osage Creek.

Although potential risks were identified for some contaminants, these estimated risks do not indicate actual impacts or effects but rather indicate that additional evaluations are warranted. Thus, site-specific field investigations consisting of biotic surveys and tissue analyses were conducted at the QROU. The biotic surveys revealed that aquatic and terrestrial communities at the QROU consist of species that would be expected to occur in the area. Internal and external examinations of small mammals collected from the site failed to show any abnormalities that could indicate adverse effects from exposure to site contaminants. No impacts to the abundance or biomass of small mammals were detected. Tissue analyses of fish and small mammals indicated uranium concentrations within the range reported in the literature for which no adverse effects have been observed. Tissue concentrations of radionuclides in small mammals collected from the QROU were comparable to levels detected in specimens from the reference sites.

On the basis of the above findings, the current levels of contamination in surface water and sediments in Femme Osage Slough and Little Femme Osage Creek do not appear to have impacted ecological resources and do not pose a future risk to biota at the site. Thus, a need for remediation of these habitats is not indicated on the basis of the ecological risk characterization. 
TABLE 7.1 Summary of Human Health Risk Estimates for the Quarry Area

\begin{tabular}{|c|c|c|c|}
\hline Pathways & $\begin{array}{c}\text { Radiological } \\
\text { Carcinogenic Risk } \\
\end{array}$ & Hazard Index & $\begin{array}{c}\text { Chemical } \\
\text { Carcinogenic Risk }\end{array}$ \\
\hline \multicolumn{4}{|l|}{ Quarry proper } \\
\hline \multicolumn{4}{|l|}{ Soil } \\
\hline External irradiation & $1 \times 10^{-5}$ & $\mathrm{NA}^{\mathrm{b}}$ & NA \\
\hline Ingestion & $4 \times 10^{-7}$ & 0.004 & $1 \times 10^{-7}$ \\
\hline Dermal & $1 \times 10^{-7}$ & 0.0009 & $1 \times 10^{-8}$ \\
\hline Inhalation & $2 \times 10^{-9}$ & $<0.0001$ & $1 \times 10^{-12}$ \\
\hline \multicolumn{4}{|l|}{ Fractures $^{\mathrm{c}}$} \\
\hline External irradiation & $3 \times 10^{-5}$ & NA & NA \\
\hline Ingestion & $7 \times 10^{-7}$ & 0.008 & $6 \times 10^{-8}$ \\
\hline Inhalation & $4 \times 10^{-9}$ & $<0.0001$ & $7 \times 10^{-13}$ \\
\hline
\end{tabular}

\section{Femme Osage Slough ${ }^{d}$}

Surface water

$\begin{array}{lccc}\text { Ingestion } & 3 \times 10^{-7} & 0.006 & 9 \times 10^{-7} \\ \text { Dermal } & 7 \times 10^{-9} & <0.0001 & 2 \times 10^{-8}\end{array}$

Sediment

$\begin{array}{lccc}\text { Ingestion } & 3 \times 10^{-8} & 0.006 & 2 \times 10^{-7} \\ \text { Dermal } & 1 \times 10^{-10} & 0.001 & 4 \times 10^{-9} \\ \text { Inhalation } & 1 \times 10^{-10} & <0.0001 & 1 \times 10^{-13}\end{array}$

Fish

\begin{tabular}{cccc} 
Ingestion & $8 \times 10^{-9}$ & 0.03 & $3 \times 10^{-6}$ \\
\hdashline Total $^{\text {e.f,g }}$ & $3 \times 10^{-5}$ & 0.05 & $4 \times 10^{-6}$ \\
\hline
\end{tabular}

a Except as otherwise noted, these risk estimates are for the recreational visitor scenario.

b $\mathrm{NA}=$ not applicable.

c Dermal contact with soils in the fractures assumed unlikely.

d Estimates for Femme Osage Slough are representative of those for Little Femme Osage Creek and Femme Osage Creek.

e Radiological carcinogenic risks are not summed with chemical carcinogenic risks because of differences in methodologies. These totals represent risks and the hazard index for the multiple pathways exposure scenario projecting a recreational visitor who is exposed to contaminants present at the quarry area (including at the quarry proper and Femme Osage Slough).

f Ingestion of groundwater is unlikely and considered to be an incomplete pathway. Nevertheless, calculations were performed for potential risk to a hypothetical resident from ingestion of and dermal contact with groundwater (see Section 5.2.3).

g External irradiation for quarry proper soil and fractures was not summed because it is not appropriate to do so; the higher of the two risks was used to calculate the total. 


\section{REFERENCES}

Bethel, W.M., et al., 1993, Small Mammal Population Analysis for the Weldon Spring Site Remedial Action Project, prepared by Lindenwood College, St. Charles, Mo., for the U.S. Department of Energy, Weldon Spring Remedial Action Project, St. Charles, Mo., May.

Chien, L., et al., 1968, "Infantile Gastroenteritis due to Water with High Sulfate Content," Canadian Medical Association Journal 99:102-104.

Dickneite, D.F., 1988, letter with enclosure from D.F. Dickneite (Environmental Administrator, Missouri Department of Conservation, Jefferson City, Mo.) to I. Hlohowskyj (Argonne National Laboratory, Argonne, Ill.), Aug. 24.

DOE: see U.S. Department of Energy.

Eisler, R., 1988, Lead Hazards to Fish, Wildlife, and Invertebrates: a Synoptic Review, Contaminant Hazard Reviews Report No. 15, Biological Report 85(1.14), U.S. Fish and Wildlife Service, Patuxent Wildlife Research Center, Laurel, Md., April.

EPA: see U.S. Environmental Protection Agency.

Figg, D.E., 1991, letter from D.E. Figg (Endangered Species Coordinator, Missouri Department of Conservation, Jefferson City, Mo.) to J.R. Powers (MK-Ferguson Company, St. Charles, Mo.), Nov. 26.

Frazer, G.D., 1995, letter from G.D. Frazer (Field Supervisor, U.S. Fish and Wildlife Service, Columbia Field Office, Columbia, Mo.) to S.H. McCracken (U.S. Department of Energy, Weldon Spring Site Remedial Action Project, St. Charles, Mo.), May 12.

Gaines, E.P., 1988, letter with enclosure from E.P. Gaines (Data Manager, Missouri Department of Conservation, Jefferson City, Mo.) to I. Hlohowskyj (Argonne National Laboratory, Argonne, Ill.), Sept. 8.

IAEA: see International Atomic Energy Agency.

ICRP: see International Commission on Radiological Protection.

International Atomic Energy Agency, 1992, Effects of Ionizing Radiation on Plants and Animals at Levels Implied by Current Radiation Protection Standards, Technical Report Series No. 332, Vienna, Austria. 
International Commission on Radiological Protection, 1983, "Radionuclide Transformations; Energy and Intensity of Emissions," ICRP Publication 38, Annals of the ICRP, Pergamon Press, Oxford.

Johnson, T.R., 1987, The Amphibians and Reptiles of Missouri, Missouri Department of Conservation, Jefferson City, Mo.

Jones, D.S., et al., 1996, Toxicological Benchmarks for Screening Contaminants of Potential Concern for Effects on Sediment-Associated Biota: 1996 Revision, ES/ER/TM-95/R2, Oak Ridge National Laboratory, Oak Ridge, Tenn., June.

Missouri Department of Natural Resources, 1992, Rules of Department of Natural Resources: Division 20-Clean Water Commission; Chapter 7-Water Quality, Code of State Regulations 10 CSR 20-7.031 (Water Quality Standards), Jefferson City, Mo.

MK-Ferguson Company and Jacobs Engineering Group, 1995, Radiological and Chemical Uptake in Game Species at the Weldon Spring Site, DOE/OR/21548-426, Rev. 1, prepared for U.S. Department of Energy, Oak Ridge Operations Office, Weldon Spring Site Remedial Action Project, St. Charles, Mo., July.

MK-Ferguson Company and Jacobs Engineering Group, 1997, Quarry Residuals Remedial Investigation Report, DOE/OR/21548-587, Rev. 1, prepared for U.S. Department of Energy, Oak Ridge Operations Office, Weldon Spring Site Remedial Action Project, St. Charles, Mo., July.

National Council on Radiation Protection and Measurements, 1991, Effects of Ionizing Radiation on Aquatic Organisms, NCRP Report No. 109, Bethesda, Md.

NCRP: see National Council on Radiation Protection and Measurements.

Rose, K.S.B., 1992, "Lower Limits of Radiosensitivity in Organisms, Excluding Man," Journal of Environmental Radioactivity 15:113-133.

Sample, B.E., et al., 1996, Toxicological Benchmarks for Wildlife: 1996 Revision, ES/ER/TM-86/R3, Health Sciences Research Division and Environmental Sciences Division, Oak Ridge National Laboratory, Oak Ridge, Tenn., June.

Schaum, J., 1991, memorandum from J. Schaum (Chief, Exposure Assessment Methods Branch, Office of Research and Development, U.S. Environmental Protection Agency, Washington, D.C.) to C. Sonich-Mullin (Acting Chief, Chemical Mixtures Assessment Branch, Office of Research and Development, U.S. Environmental Protection Agency, Washington, D.C.), Oct. 24.

Schwartz, C.W., and E.R. Schwartz, 1981, The Wild Mammals of Missouri, University of Missouri Press and Missouri Department of Conservation, Columbia, Mo. 
Suter, G.W., and C.L. Tsao, 1996, Toxicological Benchmarks for Screening Potential Contaminants of Concern for Effects on Aquatic Biota: 1996 Revision, ES/ER/TM-96/R2, Oak Ridge National Laboratory, Oak Ridge, Tenn., June.

Talmadge, S.S., and D.M. Opresko, 1996, Ecological Criteria/Toxicological Benchmarks for Screening Effects of Munitions Compounds on the Environment, prepared by Oak Ridge National Laboratory, Oak Ridge, Tenn., for U.S. Environmental Protection Agency, National Exposure Research Laboratory, Cincinnati, Ohio.

Terres, J.K., 1980, The Audubon Society Encyclopedia of North American Birds, Alfred A. Knopf, Inc., New York, N.Y.

U.S. Department of Energy, 1988, Internal Dose Conversion Factors for Calculation of Dose to the Public, DOE/EH-0071 (DE88-01429), Assistant Secretary for Environment, Safety and Health, Washington, D.C., July.

U.S. Department of Energy, 1990, Radiation Protection of the Public and the Environment, DOE Order 5400.5, Washington, D.C.

U.S. Department of Energy, 1992, Baseline Assessment for the Chemical Plant Area of the Weldon Spring Site, DOE/OR/21548-091, prepared by Argonne National Laboratory, Argonne, Ill., for U.S. Department of Energy, Weldon Spring Remedial Action Project, St. Charles, Mo., Nov.

U.S. Department of Energy, 1994a, Work Plan for the Remedial Investigation/Feasibility StudyEnvironmental Assessment for the Quarry Residuals Operable Unit at the Weldon Spring Site, DOE/OR/21548-243, prepared by Argonne National Laboratory, Argonne, Ill., for U.S. Department of Energy, Weldon Spring Remedial Action Project, St. Charles, Mo., Jan.

U.S. Department of Energy, 1994b, Quarry Residuals Sampling Plan, DOE/OR/21548-382, Rev. 1, prepared by MK-Ferguson and Jacobs Engineering Group, St. Charles, Mo., for U.S. Department of Energy, Weldon Spring Remedial Action Project, St. Charles, Mo., Jan.

U.S. Environmental Protection Agency, 1986, Quality Criteria for Water 1986, EPA 440/5-86-001, Office of Water Regulations and Standards, Washington, D.C., May.

U.S. Environmental Protection Agency, 1989a, Risk Assessment Guidance for Superfund, Volume I, Human Health Evaluation Manual, (Part A), EPA/540/1-89/002, Interim Final, Office of Emergency and Remedial Response, Washington, D.C., Dec.

U.S. Environmental Protection Agency, 1989b, Risk Assessment Guidance for Superfund, Volume II, Environmental Evaluation Manual, EPA/540/1-89/001A (OSWER Directive 9285.7-01), Interim Final, Office of Emergency and Remedial Response, Washington, D.C., March. 
U.S. Environmental Protection Agency, 1989c, Exposure Factors Handbook, EPA/600/8-89-043, Office of Health and Environmental Assessment, Washington, D.C., July.

U.S. Environmental Protection Agency, 1990, "National Oil and Hazardous Substances Pollution Contingency Plan; Final Rule (40 CFR Part 300)," Federal Register 55(35):6154-6176, Feb. 21.

U.S. Environmental Protection Agency, 1991, Human Health Evaluation Manual, Supplemental Guidance: "Standard Default Exposure Factors," memorandum from T. Fields, Jr. (Acting Director, Office of Emergency and Remedial Response) and B. Diamond (Office of Waste Programs Enforcement) to Director (Various Divisions, Regions I through IX), OSWER Directive 9285.6-03, Office of Solid Waste and Emergency Response, Washington, D.C., March 25.

U.S. Environmental Protection Agency, 1992a, Dermal Exposure Assessment: Principles and Applications, EPA/600/8-91-011B, Interim Report, Office of Research and Development, Washington, D.C., Jan.

U.S. Environmental Protection Agency, 1992b, Framework for Ecological Risk Assessment, EPA/630/R-92/001, Risk Assessment Forum, Washington, D.C., Feb.

U.S. Environmental Protection Agency, 1993, Wildlife Exposure Factors Handbook, Vol. 1, EPA/600/R-93/187a, Office of Research and Development, Washington, D.C., Dec.

U.S. Environmental Protection Agency, 1994, Water Quality Standards Handbook: Second Edition, EPA-823-B-94-005a, Office of Water, Washington, D.C.

U.S. Environmental Protection Agency, 1995a, Health Effects Assessment Summary Tables, FY-1995 Annual, EPA/540/R-95-036, Office of Solid Waste and Emergency Response, Washington, D.C., May.

U.S. Environmental Protection Agency, 1995b, Exposure Factors Handbook, EPA/600/P-95/002A (PB95-252532), Office of Research and Development, Washington, D.C., June.

U.S. Environmental Protection Agency, 1996, ECO UPDATE: Ecotox Thresholds, Intermittent Bulletin, Vol. 3, No. 2, EPA 540/F-95/038, Office of Solid Waste and Emergency Response, Washington, D.C., Jan.

U.S. Environmental Protection Agency, 1997, Integrated Risk Information System, Office of Research and Development, database accessed in February.

Valett, G., 1997, personal communication from G. Valett (MK-Ferguson Company, St. Charles, Mo.) to M. Picel (Argonne National Laboratory, Argonne, Ill.), March 24. 
Venugopal, B., and T.D. Luckey, 1978, Metal Toxicity in Mammals, Vol. 2, Plenum Press, New York, N.Y.

Whicker, F.W., and V. Schultz, 1982a, Radioecology: Nuclear Energy and the Environment, Vol. 1, CRC Press, Boca Raton, Fla.

Whicker, F.W., and V. Schultz, 1982b, Radioecology: Nuclear Energy and the Environment, Vol. 2, CRC Press, Boca Raton, Fla.

$\mathrm{Yu}, \mathrm{C}$., et al., 1993, Manual for Implementing Residual Radioactive Material Guidelines Using RESRAD, Version 5.0, ANL/EAD/LD-2, Argonne National Laboratory, Argonne, Ill., Sept. 